\title{
Population trends of common breeding and wintering birds in Hungary, decline of long- distance migrant and farmland birds during 1999-2012
}

\author{
Tibor SzÉp ${ }^{1}$, Károly NagY², Zsolt NagY², Gergö Halmos ${ }^{2}$
}

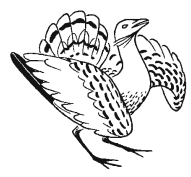

Tibor Szép, Károly Nagy, Zsolt Nagy, Gergő Halmos 2012. Population trends of common breeding and wintering birds in Hungary, decline of long-distance migrant and farmland birds during 1999-2012. - Ornis Hungarica 20(2): 13-63.

Abstract Based on the Hungarian common bird monitoring scheme (MMM), which is the longest running country-wide monitoring using formal sampling design with representative data for the main habitats in Central-Eastern Europe, we investigated the population trends of common breeding and wintering species. Habitat preference and occupancy of the common breeders, migration strategies and relationships among these characteristics could act behind the population trends. We pointed out that long distance migrant bird species had strong decreasing trends in Hungary and very probably in the entire Pannonian biogeographical region, whereas the partial and short migrant species has increasing trends. Farmland birds had declining trend, which trend became more obvious since the joining of Hungary to the EU. The negative changes in the farmland habitat could influence bird species nesting/foraging mainly in this habitat independently from their migration strategies. Our investigations let us to develop indicators on the basis of migration strategy and habitat usage of common birds to provide regular information about condition of groups of species and their habitats in Hungary and the Pannonian region. The MMM database provide unique opportunity for further investigations of several species, habitats and area specific in a part of Europe where this kind of information is rare yet.

Keywords: monitoring, Pannonian region, biodiversity indicators, Farmland Bird Indicator (FBI), climate change, migration strategies, habitat preference and occupancy

Összefoglalás A Mindennapi Madaraink Monitoringja (MMM) a leghosszabb ideje futó országos léptékủ olyan monitorozó program Közép-, Kelet-Európában, amely random mintavételi stratégia alkalmazásával reprezentatív adatokkal szolgál a régió madárállományairól és főbb élőhelyeiről. Munkánkban a gyakori fészkelő és telelő fajok állomány trendjeit, a gyakori fészkelők élőhely preferenciáját és használatát, valamint vonulási stratégiáját vizsgáltuk az állományváltozások hátterében zajló folyamatok feltárása érdekében. Kimutattuk, hogy a hosszútávon vonuló madárfajok esetében jelentös állománycsökkenés van Magyarországon és feltehetően az egész Pannon biogeográfiai régióban. Ugyanakkor a részlegesen és rövidtávon vonuló madárfajoknál növekedő állomány a jellemző. A mezögazdasági élőhelyekhez kötődő fajoknál csökkenő állományok vannak, amely jelleg különösen Magyarország EU tagsága után erősödött fel. A mezőgazdasági élőhelyeken zajló kedvezőtlen változások az ott fészkelö/táplálkozó madárfajok helyzetét jelentősen befolyásolhatják e fajok vonulási stratégiájától függetlenül. Vizsgálatunk lehetőséget ad a gyakori madárfajok vonulási és élőhelyi jellemzőin alapuló olyan indikátorok fejlesztésére, amelyek rendszeres információval szolgálnak adott fajcsoportok és az azok által használt élőhelyek állapotáról Magyarországon és a Pannon régióban. Az MMM adatbázis egyedülálló lehetőséget ad nagyszámú faj, élőhely és terület további részletes vizsgálatára Európa olyan részén, ahol ezen információk még igen ritkák napjainkban.

Kulcsszavak: monitorozás, Pannon régió, biodiverzitás indikátor, Mezőgazdasági Élőhelyek Indikátora (FBI), klímaváltozás, vonulási stratégia, élőhely preferencia és használat

${ }^{1}$ Institute of Environmental Sciences, College of Nyíregyháza, 4400 Nyirregyháza, Sóstói út 31/b, Hungary, e-mail: partifecske@freemail.hu

${ }^{2}$ MME/BirdLife Hungary, 1121 Budapest, Költö utca 21., Hungary, e-mail: halmos.gergo@mme.hu 


\section{Introduction}

Biodiversity in Europe showed large changes during the last decades, most of these changes could cause unprecedented loss without effective conservation action based on adequate information about condition of biodiversity (Balmford et al. 2003). Biodiversity monitoring schemes with relevant design in relation to the questions they want to answer, to the progress they want to follow, and to the taxa and scales they want to investigate are key for having proper information (Yoccoz et al. 2001). Monitoring of common birds species using random sampling design at national, regional and continental levels is one of the most proper biodiversity monitoring approach which could provide important information about such essential questions as the influence of habitat loss and degradation, farming practices and climate change on size and distribution of numerous bird species and on the ecological system they belong to (Gregory et al. 2005, Jiguet et al. 2012). The birds are very proper taxa for monitoring because of the large and extended network of observers, the national and international NGOs for organising and scientifically coordinating all parts of the work (design, field work, database, analysis, cooperation with scientific communities), the scientific background nationally and internationally for analysing and interpreting the information and the large interest from the public towards these species (Greenwood 2007, Gregory \& van Strien 2010).

Following the success of the Breeding Bird Survey (BBS) started in 1994 in the UK, (Gregory et al. 1996) which was the first national common bird monitoring scheme in Europe using random sampling design, the European Bird Census Council (EBCC) started to initiate similar schemes in several other European countries to form Pan-European Common Bird Monitoring Schemes (PECBMS) based on common birds at the end of the $20^{\text {th }}$ century (Gibbons 2000). The EBCC invited the MME/BirdLife Hungary in 1997 to start a new country-wide common breeding bird monitoring scheme in Hungary based on a formal design (Szép \& Gibbons 2000).

After the first pilot year in 1998, when the concept of the random sampling design and field protocol was tested with contribution of more than hundred observers and experts of the EBCC, the new scheme called Mindennapi Madaraink Monitoringja (MMM Monitoring of Common Birds) has started with the final, existing protocol in 1999 as the first common bird monitoring scheme in Central and Eastern Europe using random sampling design and collecting representative data on the level of country (Szép \& Gibbons 2000). The MMM scheme is able to monitor not only the breeding population in Hungary but by using the same field protocol data is collected from wintering populations of common bird species since 2000 (Szép \& Nagy 2002).

A number of monitoring schemes already existed in Hungary before the start of the MMM (Báldi et al. 1997), mostly organised and executed within the umbrella of MME/ BirdLife Hungary: White Stork, Ciconia ciconia, surveys since 1958; waterfowl counts since 1974; surveys of rare birds of prey species since 1974; Actio Hungarica ringing programme since 1974; integrated population monitoring of breeding Sand Martins, Riparia riparia, along the river Tisza since 1986. A scheme to monitor rare and colonial birds (known by the acronym 'RTM') was started in 1992 and uses territory mapping within observer-chosen $2.5 \times 2.5 \mathrm{~km}$ UTM squares (Szép \& Waliczky 1993). Fieldwork 
is undertaken by a hundred or so volunteers and is mostly concentrated within Important Bird Areas (IBAs). The first country-wide monitoring of common breeding birds using a standardised counting method was started only in 1988. This used the point count method to monitor breeding passerines, with a total of 20-40 areas covered annually by 20-50 participants (Waliczky 1991). Sites were selected by the observers and were mainly in forested areas. Because of the low level of participation, the bias towards forested habitats in relatively few geographical regions of Hungary and observer choice of sites, population trend data produced by this scheme cannot be taken as representative of trends for common breeding birds in Hungary as a whole.

The information provided for breeding and wintering common bird species by the MMM scheme in Hungary since 1999 using standard methods for trend analysis (TRIM, Pannekoek \& van Strien 2001) has importance not only for Hungary but for large part of Central and Eastern part of Europe, covered by the countries of the former Eastern Bloc, many of them joined to the EU since in 2004. In most of those countries, monitoring of common birds, representative on the level of country has not or partly existed before 1999 and new monitoring schemes in these countries follow the PECBMS standard has started later then the MMM. The different geographic, climatic, economic, political and environmental conditions of these countries compared to former EU member countries makes it important to have proper database, compatible with existing databases in Europe for analysing the kind of effects e.g. as Common Agricultural Policy (CAP), Agri-Environment Schemes (AES) of EU (Butler et al. 2010) and climate change (Both et al. 2010).
Biodiversity indicators based on annual indices of common bird species related to specific habitat has an increasing importance in the World (Butchart et al. 2010) following the successful application of it in the European Union (Gregory \& van Strien 2010). The farmland bird indicator (FBI) is the most widely used such multi-species indicator in Europe, which based on population trends of common bird species related to farmland habitat and indicates the adverse changes in this habitat in relation to the Common Agricultural Policy (CAP) in many EU countries (Gregory et al. 2005). Several countries and the EU are increasingly using these measures to assess sustainable development strategies, environmental and ecosystem health (Gregory \& van Strien 2010).

The concept developed by Gregory et al. $(2003,2005)$ let to consider more indicators for other habitats or group of species when relevant classification of species available based on quantitative data and/or expert judgement guided by additional information. The classification of species to a specific habitat generally could be proper for most of the species in each region and country in Europe, however in the case of some species marked differences exist among regions and countries because of natural and human related (e.g. different farming practices) reasons. The EBCC has recognised this problem and suggested different species for the main European biogeographical regions to calculate indicators for farmland, forest and others habitat types nationally, regionally and continentally (http://www.ebcc. info) (Gregory \& van Strien 2010), based on Tucker and Evans (1997) and on experts (invited from most of the European countries) judgement. The common bird monitoring schemes with random sampling design can 
make it possible to use quantitative approaches to classify species to specific habitats depending on the available habitat information (Julliard et al. 2003, 2006).

In Hungary, country-wide habitat survey was carried out in the frame of the CORINE land cover program between 1998-2003 producing a high resolution 1:50 000 GIS database (Büttner \& Maucha 2006), which coincided with the start of the MMM scheme where locations of field observations are in a GIS database. These databases allow us to investigate the habitat preference and habitat occupancy of the common bird species at the level of landscape and to verify existing classification for the Hungarian populations of these species and developing further indicators considering habitat and migration strategies of the breeding species based on ringing data (Csörgő et al. 2009).

Our aim in this paper to provide an overview of the main characteristics of the Hungarian common bird monitoring scheme (MMM), from the sampling design, monitoring protocol until the trend estimation. We aim to provide information about the frequency and trends of bird species observed during the breeding and wintering season in Hungary. Based on the MMM database with combination of existing $\mathrm{CO}$ RINE land cover GIS data, we overview the habitat occupancy and preference of the common breeding bird species in Hungary, considering the four main habitat types (urban, farmland, forest, wetland) which provide option to develop relevant habitat related indicators in this region. We investigate differences in population trends between species groups with different habitat classification, occupancy and preference and with different migration strategies.

\section{Material and Methods}

The Hungarian common bird monitoring scheme (MMM) is based on point count in grid cells with semi-random sampling design. The surveyed sites are $2.5 \times 2.5 \mathrm{~km}$ UTM squares (Universal Transverse Mercator geographic coordinate system), randomly selected for each observer within a minimum of $10 \mathrm{~km}$ radius area around a locality specified by the observer. Observers carried out 5 minute long point counts at 15 points, randomly selected from the 25 potential points within the $2.5 \times 2.5 \mathrm{~km}$ UTM squares, where points were separated by $500 \mathrm{~m}$. The staff of the MMM scheme send high resolution map (1:15 000) of the selected $2.5 \times 2.5 \mathrm{~km}$ UTM squares which contains position and 50, 100 $\mathrm{m}$ radius area of the 25 points within the squares. Coordinates of the UTM square and 25 points in a GoogleEarth format are available for the observers on the MMM website (mmm.mme.hu). Selection of the points within the UTM squares done in the first year of the selection of the UTM squares. In the first year the observers received a list of the 15 selected points (using latin square approach) from the staff of the MMM, which they must survey within the UTM squares. The observers could change some points to another one only in the case of specific situation (closed area, very difficult to reach by e.g. river, highway etc.) using a random list of points to change the formerly suggested to another one. The points which were selected and surveyed in the first year investigated during the following years. Each year, the observers asked to draw a simple map for the $100 \mathrm{~m}$ radius area of each point in a specific field book to show the different habitat patches, using Hungarian habitat classification codes (Á-NÉR; Fekete et al. 1997). During the five minute counts the observers asked to 
indicate in the field book the distance of the observed birds using 0-50, 51-100, 100-200 $\mathrm{m}$ distance categories and a separate category for birds flied over the $100 \mathrm{~m}$ radius area of the points.

Survey of the breeding population happen twice per spring with minimum 2 weeks between sampling sessions from mid April to mid June since 1999. The count at the selected points took place between 5 and 10 am, when wind speed is less then $5 \mathrm{~m} / \mathrm{s}$ and there is no rain. Survey of the wintering population happen once in January since 2000. The count at the selected points took place between 6 and 16 hour, when wind speed is less then $5 \mathrm{~m} / \mathrm{s}$ and there is no raining/ snowing. Time of the observation and wind speed (Beaufort scale) recorded at each point in the field book.

Observers asked to fill a form (which contains all bird species occurring in Hungary) after the field work in which form they indicated for each species their skill of identification of the species using four categories (by view, by sound, by view and sound, uncertain). This confidently handled database let us to consider the reason of absence of species in the surveyed $2.5 \times 2.5 \mathrm{~km}$ UTM square, when large number of observers $(\sim 1000$ observers) with various identification skills were contributed (Szép \& Gibbons 2000).

For each species, we retained the maximum count per point for the two spring sessions and one count for the winter session. Counts were summed for the 15 points within each square for each year. Between 1999 and 2012, 15199 points in 984 pieces of $2.5 \times 2.5 \mathrm{~km}$ UTM squares were surveyed during the breeding season by 762 observers. Between 2000-2012, 5768 points in 401 pieces of $2.5 \times 2.5 \mathrm{~km}$ UTM squares were surveyed during the wintering season by 302 observers.
For the analysis, we considered only the field data of points which matched the requirement of field protocol and only for data of species where the given observer was able to identify the species by view and/or sound. In the case of the spring survey, there were 12219 points in 824 pieces of $2.5 \times 2.5 \mathrm{~km}$ UTM squares which were surveyed according to the standard field protocol (Figure 1a). $240 \mathrm{bird}$ species were seen/heard at these points, 389542 individuals of 214 species surveyed within $100 \mathrm{~m}$ radius area of these points (Supplement 1). In the case of the winter survey there were 5380 points in 371 pieces of $2.5 \times 2.5 \mathrm{~km}$ UTM squares which were surveyed according to the standard field protocol (Figure 1b). 143 bird species were seen/heard at these points, 307675 individuals of 140 species were surveyed within 200 $\mathrm{m}$ radius area of these points (Supplement 2).

Frequency of the surveyed breeding/wintering species was calculated annually by using the ratio of $2.5 \times 2.5 \mathrm{~km}$ UTM squares where the given species was seen/heard to all $2.5 \times 2.5 \mathrm{~km}$ UTM squares where the given species was surveyed by observers who were able identify the given species by view and/or song. Mean frequency with SE was estimated from annual frequency of the 1999-2012 years for breeding populations and from 2000-2012 years for wintering populations, observed minimal and maximal annual frequency values are given as well (Supplement 1, 2).

Habitat occupancy and preference of the surveyed species (Chamberlain \& Fuller 1999) during the breeding season were investigated on the base of CORINE land cover CLC50 GIS database made between 1998-2003 in Hungary (Büttner \& Maucha 2006). The spatial resolution of the CORINE CLC50 is 4 ha (1 ha for water bodies). We used this database to classify the habitat 

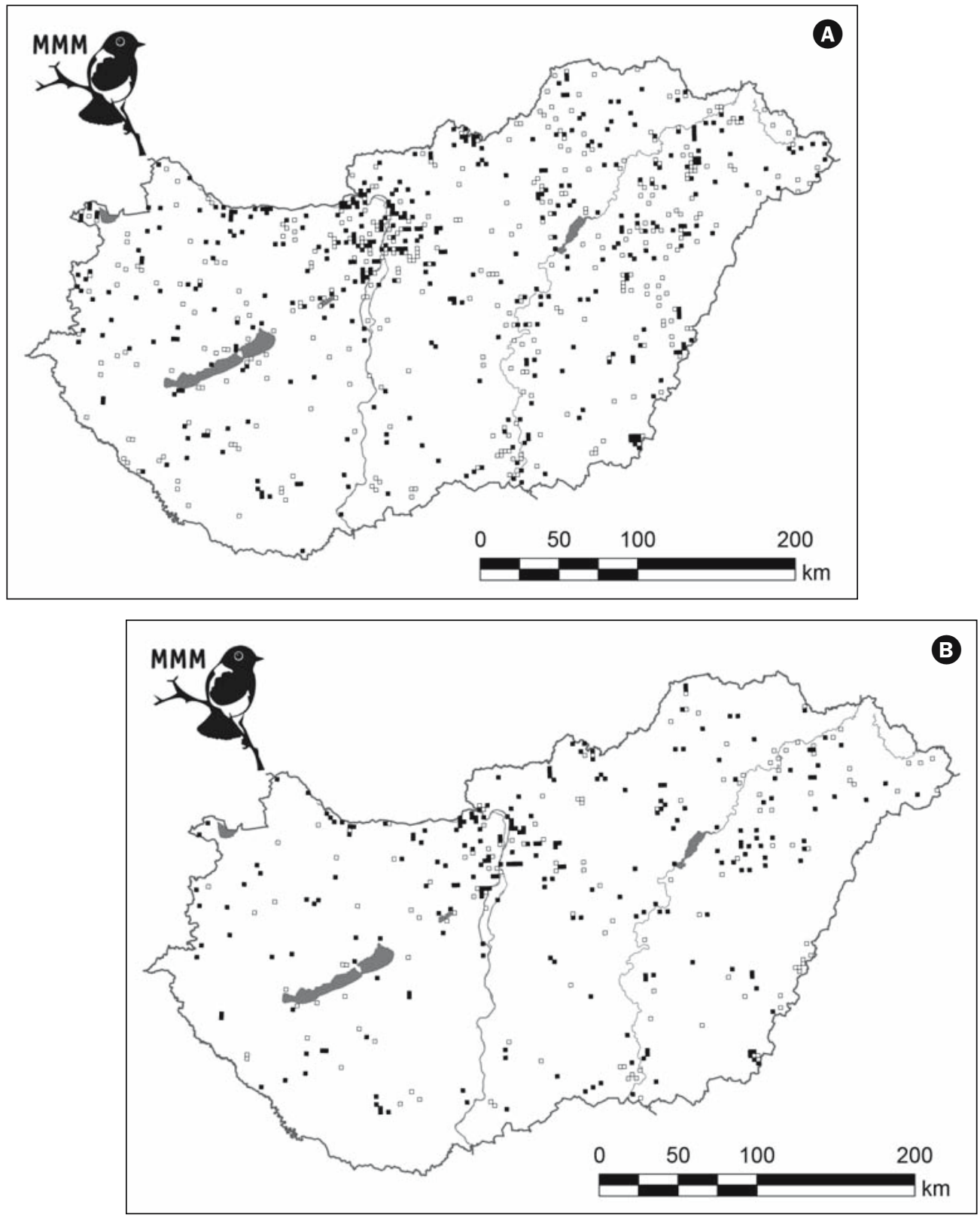

Figure 1. $2.5 \times 2.5 \mathrm{~km}$ UTM squares in Hungary surveyed following the standard protocol of the MMM (a) during the breeding seasons of 1999-2012, (b) during the wintering seasons of 20002012. Open squares indicated UTM squares surveyed in one year, black squares surveyed more than one year

1. ábra Azon 2,5×2,5 km UTM négyzetek Magyarországon, amelyeket az MMM standard protokollja alapján mértek fel (A) a fészkelési időszakban 1999-2012 során, (B) a telelési időszakban 2000-2012 során. Az üres négyzetek azokat az UTM négyzeteket jelzik, amelyeket csak egy évben, a fekete négyzetek azokat, amelyeket több mint egy évben mértek fel 


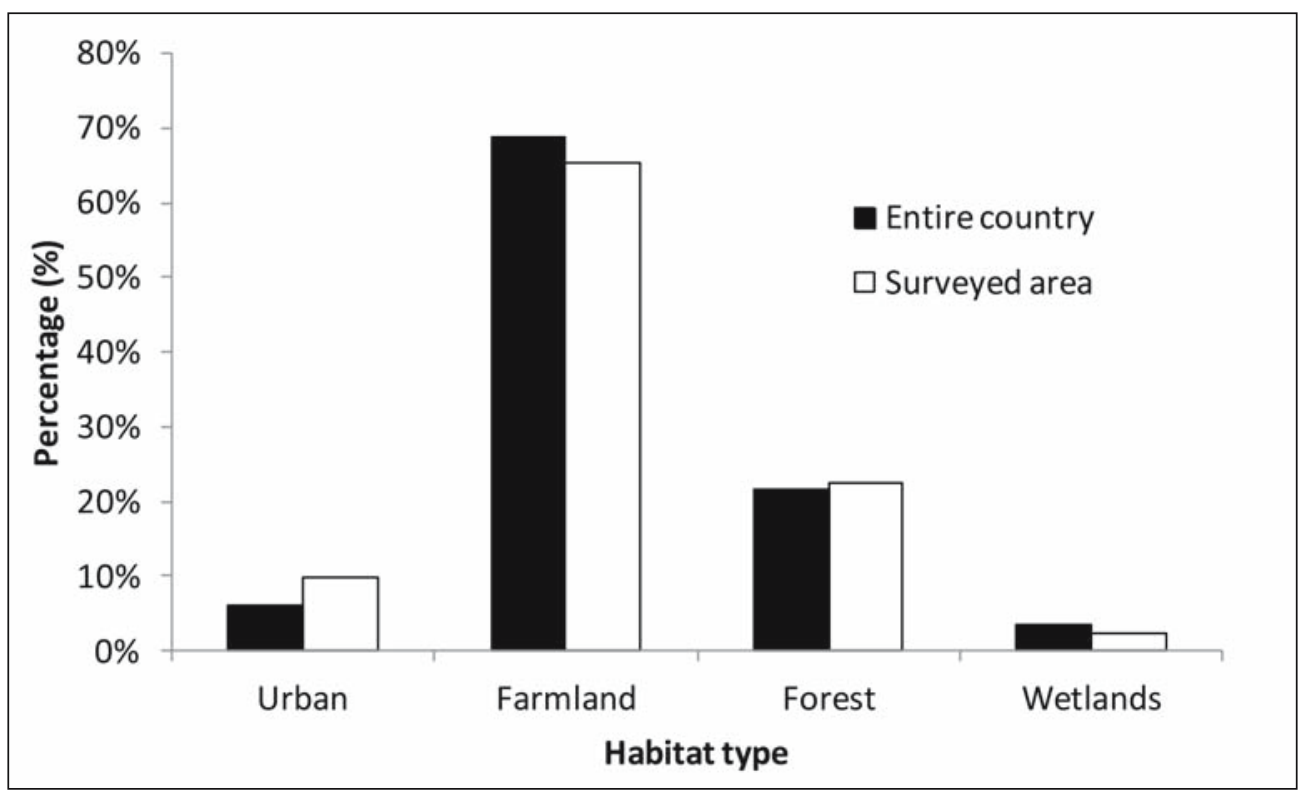

Figure 2. Distribution of the studied four main habitat categories (based on CORINE land cover) in the entire area of Hungary and in the $100 \mathrm{~m}$ radius area of the surveyed points (surveyed following the standard protocol of the MMM)

2. ábra A vizsgált négy fő élőhely típus (urbán, mezőgazdasági, erdei, vizes, CORINE land cover adatbázis alapján azonosítva) százalékos területi aránya Magyarországon (Entire country) és az MMM keretében standard módon felmért 100 m sugarú megfigyelési pontok területén (Surveyed area)

types of $100 \mathrm{~m}$ radius area of each surveyed points. Habitat was classified into four coded categories: farmland, forest, wetlands and urban habitats on the base of CORINE 1:50000 scale Land Cover first level of habitat description (1: urban, 2: farmland, 3: forest, 4-5: wetlands). Some CORINE habitats (3.2.1.1., 3.2.1.2., 3.3.3.1., 3.3.3.2., 3.3.3.3.) which mainly used for farming instead of forestry in Hungary were classified as farmland habitats. Percentage of the investigated four main habitat categories within the $100 \mathrm{~m}$ radius areas of the surveyed points (points surveyed following standard protocol considered, $n=12$ 219) showed similar distribution as the percentage of these habitats in the entire country (Figure 2). The percentages of the urban and forest habitats were little higher in the surveyed area compared to the country total.

Habitat preference of the species was investigated by comparing the relative density of the species in the studied four main habitat categories (Chamberlain \& Fuller 1999). The habitat with the highest relative density was identified as preferred habitat of the species. Species regarded as having mixed habitat preference, when relative density was high in more than one habitat. The relative density (observed individual per $\mathrm{km}^{2}$ in the breeding season) of each species in each main habitat type was calculated on the base of individuals counted in $100 \mathrm{~m}$ radius area of the points where more than $2 / 3(66 \%)$ of the $100 \mathrm{~m}$ radius area covered by the given main habitat type (11062 points, $90.5 \%$ of 
the all surveyed 12219 points were considered) (Supplement 3). In the case of points where survey was made for several years, the mean relative density value was used. All points were considered where the observers were able to identify the given species by view and/or song including zero observations. There were 175 points where birds were not observed, and $97 \%$ of these points were covered with farmland habitat type.

We investigated the distribution of the Hungarian breeding population of the species among the four main habitat categories to investigate the habitat occupancy of the species in Hungary, based on the relative density of the species estimated by the MMM (Supplement 3). On the basis of mean relative density of the species in the studied four habitat types, we estimated the population size for each species for the four main habitat categories, using the size of the area of the given habitat types in Hungary and investigated the proportion of the estimated population size in the given habitat to the country total. The main habitat type used by the species in Hungary was selected when more than $2 / 3(66 \%)$ of the estimated population of the given species observed in the given habitat type (urban, farmland, forest, wetlands). Habitat occupancy regarded as mixed in other cases.

The annual population trends for each species were calculated using TRIM software (Pannekoek \& van Strien 2001) which allows for missing counts in the time series and produces unbiased yearly indices and standard errors using Poisson regression (log-linear models; McCullagh \& Nelder 1989). TRIM is used frequently in the case of national common bird monitoring schemes in Europe (Gregory et al. 2008, 2009). In the case of the breeding population, we used annual counts within the 100 m radius area of the surveyed 15 points in the $2.5 \times 2.5$ $\mathrm{km}$ UTM squares for trend analysis, whereas in the case of the wintering population, we used annual counts within the $200 \mathrm{~m}$ radius area, because of the lower bird density and better detectability in winter. For the analysis of the trend we considered only $2.5 \times 2.5$ $\mathrm{km}$ UTM squares, which were surveyed at least in two years (407 UTM squares in the breeding season, 239 UTM squares in the wintering season).

For the trend modelling we used the 'Time Effect' basic model of the TRIM (expecting effects for each site and year) (Pannekoek \& van Strien 2001). In the case of less common species for which no data was available for some years, linear trend with change points (for years when data available) model of TRIM (Pannekoek \& van Strien 2001) was used following the suggestions of the PECBMS for national trends (www.ebcc.info/ $\mathrm{pecbm} / \mathrm{html}$ ). The counts were weighted to handle the oversampling in some counties (larger percent of area surveyed in the given county, in the given year for the given species comparing to the entire surveyed area than the ratio of the area of the given county to the entire country). Missing counts of particular sites were estimated ('imputed') from changes in all other sites (Pannekoek \& van Strien 2001). The TRIM produced imputed yearly indices for each species which were used for calculating indicators (available: mmm.mme.hu). Indices of the first year of the survey (breeding season: 1999, wintering season: 2000) was the base year with value 1 and all other indices were calculated relative to this base time point. In addition, serial correlation was taken into account. The estimated slopes of the population trend (overall additive slope, based on imputed data, TRIM) reflect average percentage change per year. The overall slope estimate in TRIM 
software is converted into discrete categories (trend classification, van Strien et al. 2001). The category depends on the overall slope as well as its $95 \%$ confidence interval. Based on the EBCC classification we categorized the bird species on a five-point scale: steep decline $(-2)$, moderate decline $(-1)$, stable $(0)$, moderate increase $(+1)$, and strong increase $(+2)$. Steep decline or strong increase classified by TRIM when slope was lower/ higher than $(-/+) 5 \%$ per year, $((-/+) 5 \%$ would mean halving/doubling in abundance within 15 years) (van Strien et al. 2001). Moderate decline/increase was considered when the trend was significant but its level does not reach the level of steep decline/increase. When the trend was not significant but the confidence limits were sufficiently small, the species was classified as a stable population. If the trend of the given species was not significant and the confidence limits were large, the population trend was classified as uncertain (van Strien et al. 2001). During comparison of trends of different groups of species we only considered species which trend was significantly increasing, decreasing or classified as stable. Calculating different indicators we considered species with uncertain trends as well but we excluded data of species from our analysis for which uncertain trend coincided with large standard error of the estimated slope $(\mathrm{SE}>0.1)$ to avoid potential biases arising from substantial changes remaining unnoticed due to the large standard errors of the trend estimate.

Migratory strategy of breeding species in Hungary was classified as resident, partial and short distance and long-distance migrant on the base of the Hungarian Bird Migration Atlas (Csörgö et al. 2009). We used the Hungarian Bird Migration Atlas (Csörgő et al. 2009) to classify the wintering species in Hungary in categories as species formed fully/partly by Hungarian breeding population and as species formed fully by foreign populations.

Indicators, based on groups of species classified by migration strategies, habitat occupancy/preference, sources of wintering population in Hungary and EBCC PECBMS list for Continental biogeographical regions of Europe (version $2013 \mathrm{http}: / / \mathrm{www}$. ebcc.info), calculated by geometric mean of annual indices (with standard error) of the species considered in the given group following Gregory et al. (2005). We used linear regression to analyse the trends of the indicators.

\section{Results}

\section{Species frequency in the breeding and wintering season}

In the breeding season, from the observed 240 species, mean annual frequency of 106 bird species was higher than 5\% (Supplement 1) and these species were considered for further analysis (Table 1). During the winter, 140 species were detected from which mean annual frequency of 57 species was higher than 5\% (Supplement 2) and considered for trend estimation of wintering species (Table 2).

\section{Habitat occupancy and preference of common bird species in the breeding seasons}

There were 211 species which were observed within $100 \mathrm{~m}$ radius area of the 11062 points where main habitat type was classified on the basis of CORINE land cover (Supplement 3). Habitat occupancy, classified by habitat where more than $2 / 3$ of the population of the 
given species observed, showed that among the investigated 106 species the farmland habitat was the most used (44 species, 41.5\%), the second was the forest habitat (21 species, $19.8 \%$ ), the third was the wetland (4 species, $3.8 \%$ ). There was no species where $2 / 3$ of the population observed in urban habitat, however there were 37 species (34.9\%) where the population occurred in large percent in more than one habitat, which were categorized to mixed habitats (Table 3).

Each species which preferred the farmland habitat (20 species) were observed in that habitat to the largest percentage as well. In the case of species with preference of forest habitat (36 species), more than half of them observed in the forest habitat type (58.3\%) and the rest $(41.7 \%)$ used mixed habitats dominantly. In the case of species which preferred the wetland habitat (22 species), most of them $(50 \%)$ occurred dominantly in the farmland habitat, the second most used habitat was the mixed type (31.8\%) and only 4 species $(18.2 \%)$ observed dominantly in wetland habitat. Species with main preference of urban habitat (16 species) occurred the most in mixed habitats $(62.5 \%)$ and the rest in farmland $(37.5 \%)$. Species with no specific habitat preference (12 species) occurred the most in farmland habitat (58.3\%) and the rest in mixed habitats (41.7\%) (Table 3).

\section{Habitat classification}

For some species the habitat classification for the Continental part of Europe suggested by the Pan-European Common Bird Monitoring Scheme (PECBMS) differs from the results we obtained for the population breeding in Hungary. Based on the available data there is opportunity to consider additional/different species and categories for classification.
Among the 22 species classified as farmland bird species in the PECBMS there were two (Emberiza citrinella, Streptopelia turtur) which density was the highest in forest habitats and the habitat occupancy indicated mixed habitats (farmland and forest) in Hungary, thus the best to consider these species as species using mixed habitats (Table 1). There were 17 species in the PECBMS list suggested as common birds which use 'others' habitats (no farmland/forest birds or using mixed habitats), however more than $2 / 3$ of the population of these species occurred in farmland habitats in Hungary, thus the breeding population of these species was highly dependent on farmland habitats. Among these 17 species, there were four species (Phasianus colchicus, Merops apiaster, Anthus campestris, Locustella naevia) which species preferred the farmland habitats, the rest preferred the urban habitat (Pica pica, Carduelis carduelis), the wetland habitat (Ardea cinerea, Circus aeruginosus, Tringa totanus, Acrocephalus schoenobaenus, Acrocephalus palustris, Acrocephalus arundinaceus) or had no obvious preference (mixed habitats) (Buteo buteo, Upupa epops, Motacilla alba, Oenanthe oenanthe, Corvus corone cornix). Above the formerly mentioned species, there were 7 breeding species which populations dominantly $(2 / 3)$ occurred in farmland habitat in Hungary and needed to reconsider as species highly related on farmland. Among these species three preferred farmland (Circus pygargus, Coturnix coturnix, Tringa glareola), three preferred wetland (Botaurus stellaris, Egretta alba, Riparia riparia) and one preferred urban habitat (Falco subbuteo).

In the case of 22 species classified as forest bird by PECBMS, there were 6 species (Accipiter nisus, Picus viridis, Anthus trivialis, Sylvia atricapilla, Phylloscopus trochilus and Muscicapa striata) which used mixed 
habitats in Hungary on the base of habitat occupancy and their populations depend on more than one habitat (farmland and forest). There were five species (Dendrocopos major, Lullula arborea, Erithacus rubecula, Parus caeruleus, Fringilla coelebs) which suggested as species with 'others' habitat occupancy by PECBMS, however these species preferred the forest habitat and more than $2 / 3$ of the population occurred in forest habitat in Hungary.

There were four species among the 106 most common species (Phalacrocorax carbo, Nycticorax nycticorax, Anser anser, Locustella luscinioides) which population dominantly $(2 / 3)$ occurred in wetland habitat in Hungary.

There were 37 species where dominant part of the population occurred in more than one habitat type in Hungary and we regard them as species using mixed habitat type. Habitat preference of these species: (27\%) urban, (40.5\%) forest, (18.9\%) wetland, (13.5\%) no preference (mixed habitat). 25 species of these species were classified in 'others' category by the PECBMS as well.

\section{Population trend and migration strategies}

There were 26 species with decreasing, 28 species with increasing and 20 species with stable population trends and 33 species with uncertain trend on the basis of trend classification criteria of the TRIM program (Table 1). There was a significant difference in the population trends (decreasing, stable, increasing) regarding the different migration strategies (resident, partial and short distance migrant, long distance migrant) $\left(\chi^{2}=14.494\right.$, $P=0.005$, Fisher's Exact Test) (Figure 3).

There was no difference in the population trend between resident and partial and short distance migrant species $\left(\chi^{2}=0.284, P=1\right.$, Fisher's Exact Test). The number of species with increasing trend was higher $(52.6 \%$, $53.6 \%$ ) than the number of species with decreasing or stable trend $(26.3 \%, 21.4 \%)$.

Comparison of population trends of long distance migrant species to resident and partial and short distance migrant species showed that long distance migrant species had different population trends $\left(\chi^{2}=14.420\right.$, $P<0.001$, Fisher's Exact Test). In the case of the long distance migrant species the proportion of species with decreasing population trend $(57.8 \%)$ was higher than species with increasing $(7.7 \%)$ and stable population trend. Among the long distance migrant species there were only two species (Jynx torquilla, Ficedula albicollis) with increasing population trend.

\section{Population trends and habitat occupancy}

The population trends showed different pattern among species using different habitats classified by habitat occupancy (farmland, forest and mixed) $\left(\chi^{2}=15.714, P=0.003\right.$, Fisher's Exact Test) (Figure 4). There was significant difference in the trends between the number of species mainly using farmland habitat compared to the number of species mainly using forest habitat $\left(\chi^{2}=15.192\right.$, $P<0.001$, Fisher's Exact Test). More than half $(51.6 \%)$ of the species which dominantly occurred in farmland habitat had decreasing trends, and only $16.1 \%$ had increasing trends. In the case of species which mainly occurred in forest habitat, increasing trends found for $73.3 \%$ of the species and only one species (Lullula arborea) of this group $(6.7 \%)$ had decreasing trend.

Decreasing trends were more common among farmland birds compared to species with mixed habitat usage but the differen- 


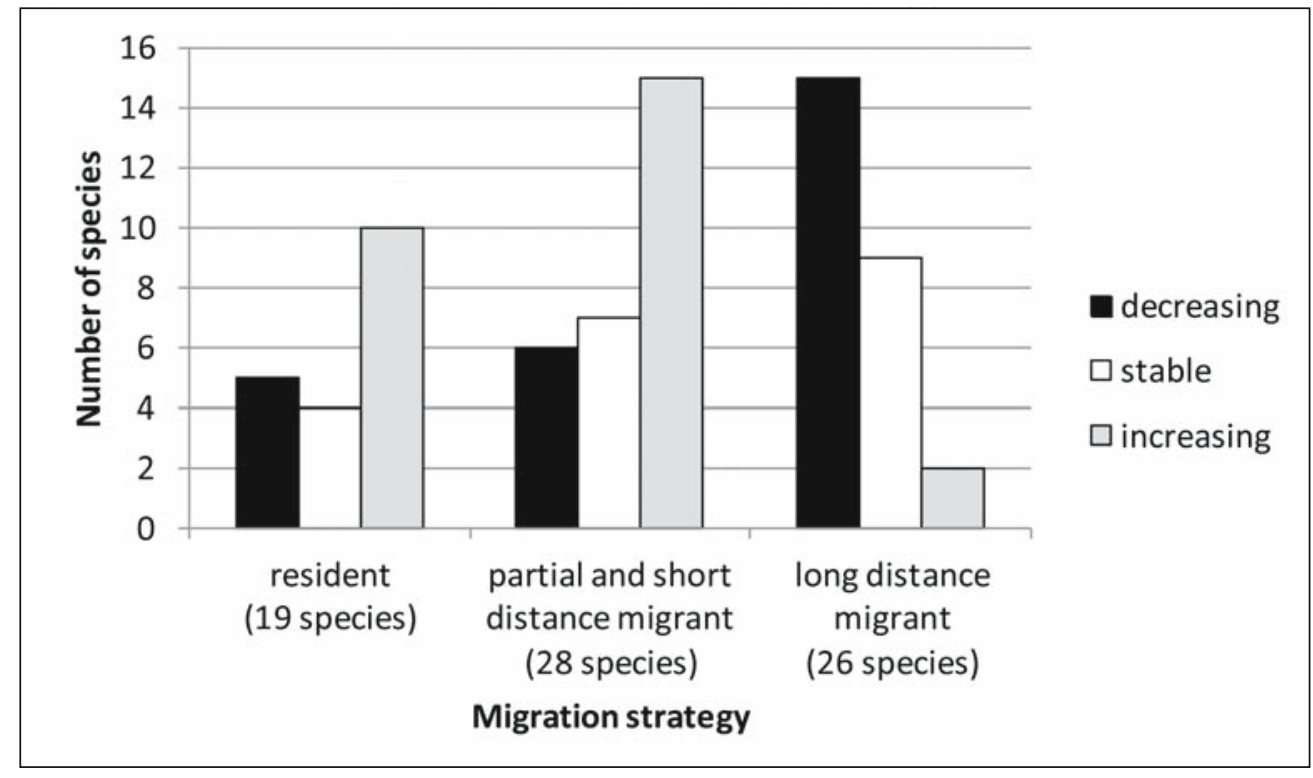

Figure 3. Population trends and migration strategies of species for which significant decreasing, increasing and stable trend were properly estimated by the TRIM software

3. ábra A TRIM program alapján szignifikáns csökkenő, stabil és növekedő állomány trendet mutató fajok száma a vizsgált három vonulási stratégiával (állandó, részlegesen/rövidtávon vonuló, hosszútávon vonuló) jellemezhető csoportok esetében. A csoportonként figyelembe vett fajok száma zárójelben megadva

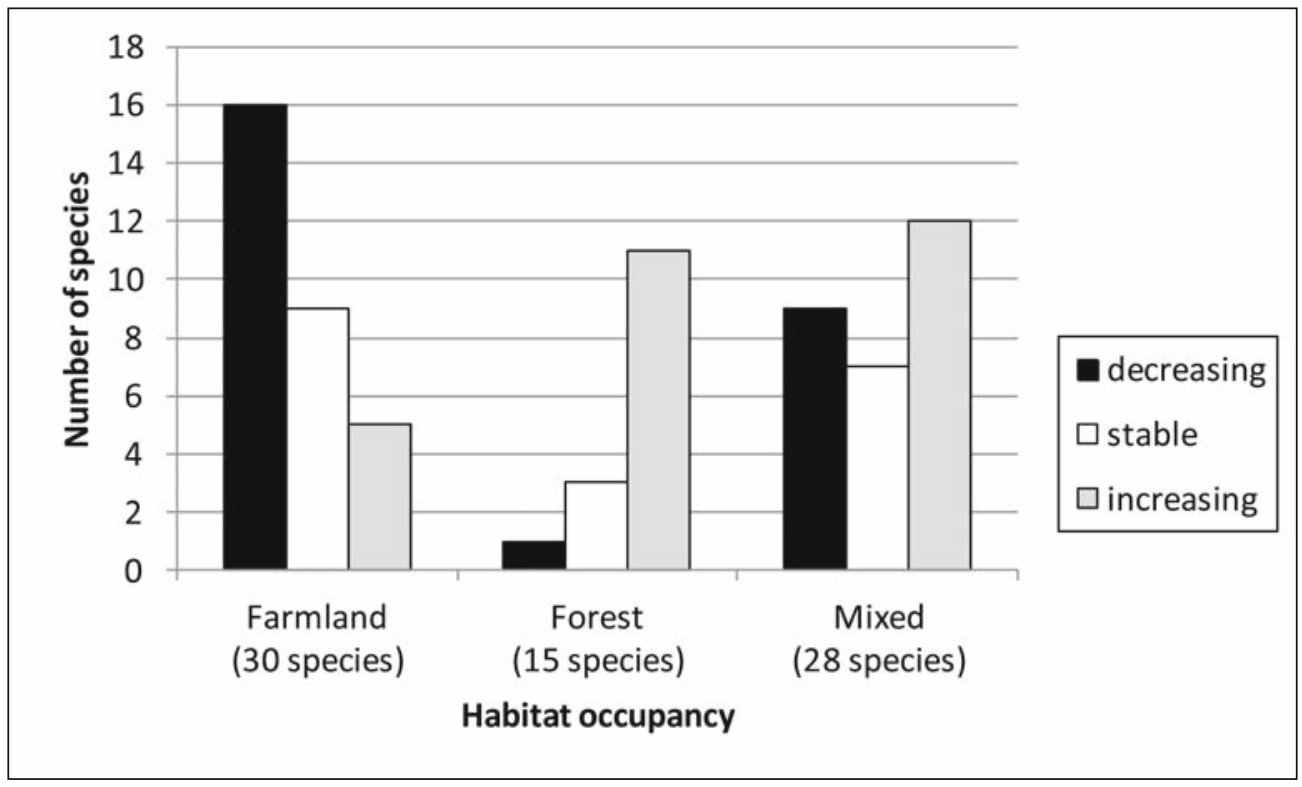

Figure 4. Population trends and habitat occupancy of species for which significant decreasing, increasing and stable trend were properly estimated by the TRIM software

4. ábra A TRIM szoftver alapján szignifikáns csökkenő, stabil, növekedő állomány trendet mutató fajok száma a vizsgált három élőhely használattal (mezőgazdasági, erdei, vegyes) jellemezhető csoportok esetében. A csoportonként figyelembe vett fajok száma zárójelben megadva 

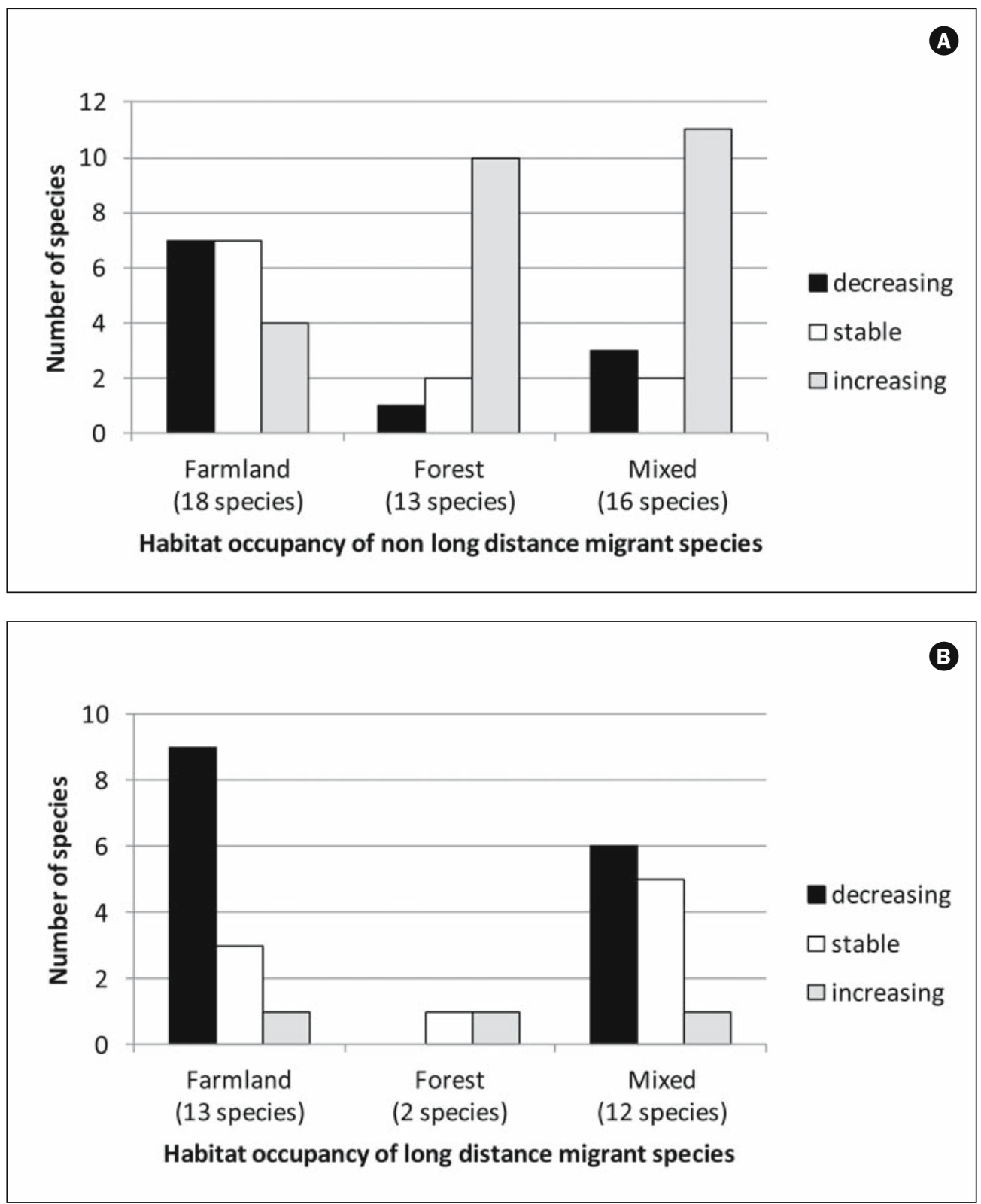

Figure 5. Population trends and habitat occupancy of (A) resident, partial and short distance migrant species and (B) long distance migrant species for which significant decreasing, increasing and stable trend were properly estimated by the TRIM software

5. ábra A TRIM program alapján szignifikáns csökkenő, stabil, növekedő állomány trendet mutató, (A) nem hosszútávon vonuló, (B) hosszútávon vonuló fajok száma a vizsgált három élőhely használattal (mezőgazdasági, erdei, vegyes) jellemezhető csoportok esetében. A csoportonként figyelembe vett fajok száma zárójelben megadva 
ce was not significant $\left(\chi^{2}=5.126, P=0.087\right.$, Fisher's Exact Test). Increasing trend among species which use forest habitat was more common than among species which use mixed habitat but the difference was not significant between these groups $\left(\chi^{2}=4.383\right.$, $P=0.107$, Fisher's Exact Test).

\section{Population trends, migration strategies and habitat occupancy}

Among the 47 non long distance migrant species (resident and partial and short distance migrant), there were significant difference between number of species with increasing, stable and decreasing trends using different habitats $\left(\chi^{2}=11.341, P=0.018\right.$, Fisher's Exact Test) (Figure 5a). Population increase was less common (22.2\%) among species which use mainly farmland habitat, comparing to the number of species mainly using forests $(76.9 \%)\left(\chi^{2}=8.814, P=0.015\right.$, Fisher's Exact Test) and compared to number of species which mainly use mixed habitat $(68.8 \%)\left(\chi^{2}=7.269, P=0.026\right.$, Fisher's Exact Test). There was no significant difference between the number of species which use mainly forest and mixed habitats $\left(\chi^{2}=0.832, P=0.844\right.$, Fisher's Exact Test $)$. In the case of these groups the most species had increasing trends.

In the case of the 27 long distance migrant species for which proper trend data was available to classify population trends (decreasing, stable, increasing) there was no significant difference between groups of species with different habitat occupancy $\left(\chi^{2}=5.106\right.$, $P=0.262$, Fisher's Exact Test) (Figure 5b).

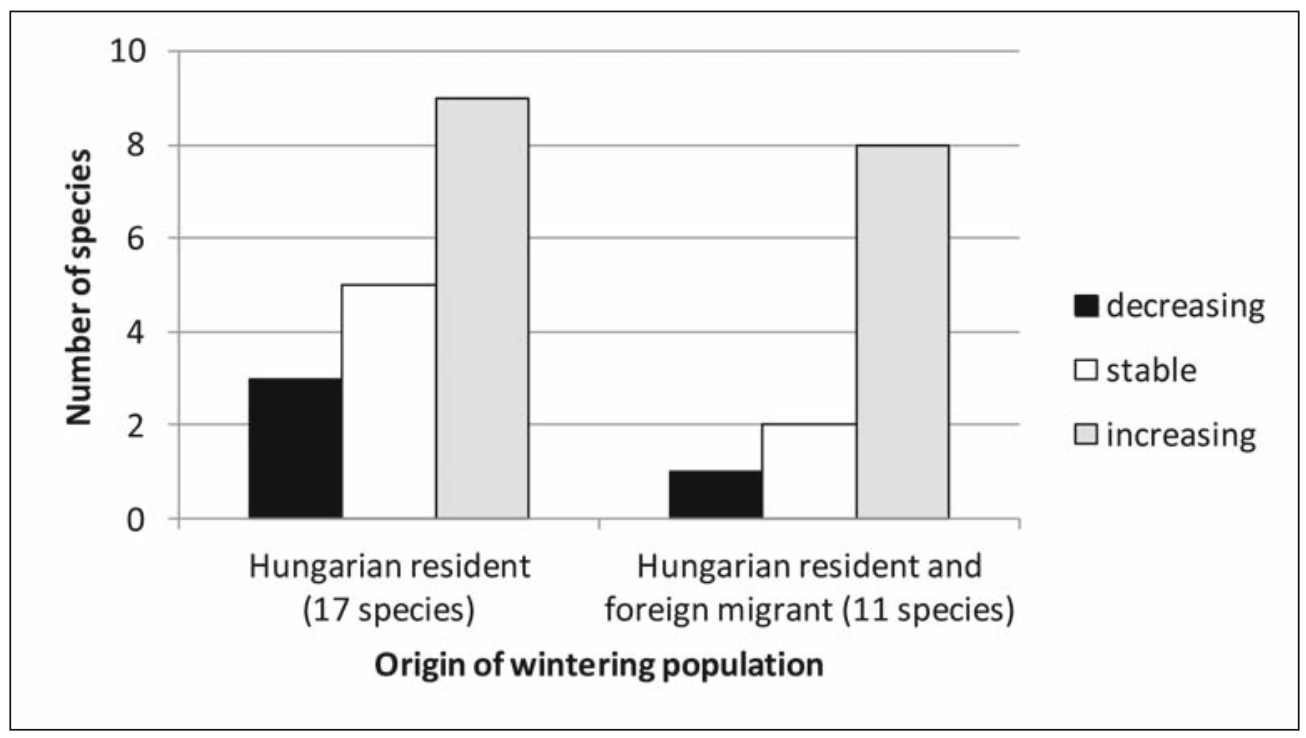

Figure 6. Population trends of wintering species and origin of these populations (1) mainly from Hungarian resident population, (2) from Hungarian resident and foreign migrant populations, for which significant decreasing, increasing and stable trend were properly estimated by the TRIM software

6. ábra A TRIM program alapján szignifikáns csökkenő, stabil, növekedő állomány trendet mutató telelő fajok száma az állományok származása alapján (1- főként magyar állandó állomány, 2- magyar és külföldi vonuló állomány) jellemezhető csoportok esetében. A csoportonként figyelembe vett fajok száma zárójelben megadva 


\section{Population trend of the wintering species in Hungary}

There were 4 species with significantly decreasing population, 7 species with stable population trend and 17 species with significantly increasing population (Table 2) based on the trend classification criteria of the TRIM.

Population trends of the species which wintering population mainly formed by the Hungarian resident population did not show difference from species formed by mixed Hungarian resident and foreign wintering populations $\left(\chi^{2}=1.063, P=0.638\right.$, Fisher's Exact Test) (Figure 6).

\section{Indicators of the breeding season}

For the calculation of indicators of different migration strategies and habitat occupancy, we considered the annual indices of 101 species. From the 106 species for which trends were estimated, we excluded data of five species (Anser anser, Circus pygargus, Tringa glareola, Apus apus, Anthus pratensis) with extremely uncertain trends, which showed very high standard error of the estimated slope $(\mathrm{SE}>0.1)$.

\section{Migration strategies}

We calculated three indicators from the annual population indexes of the studied spe-

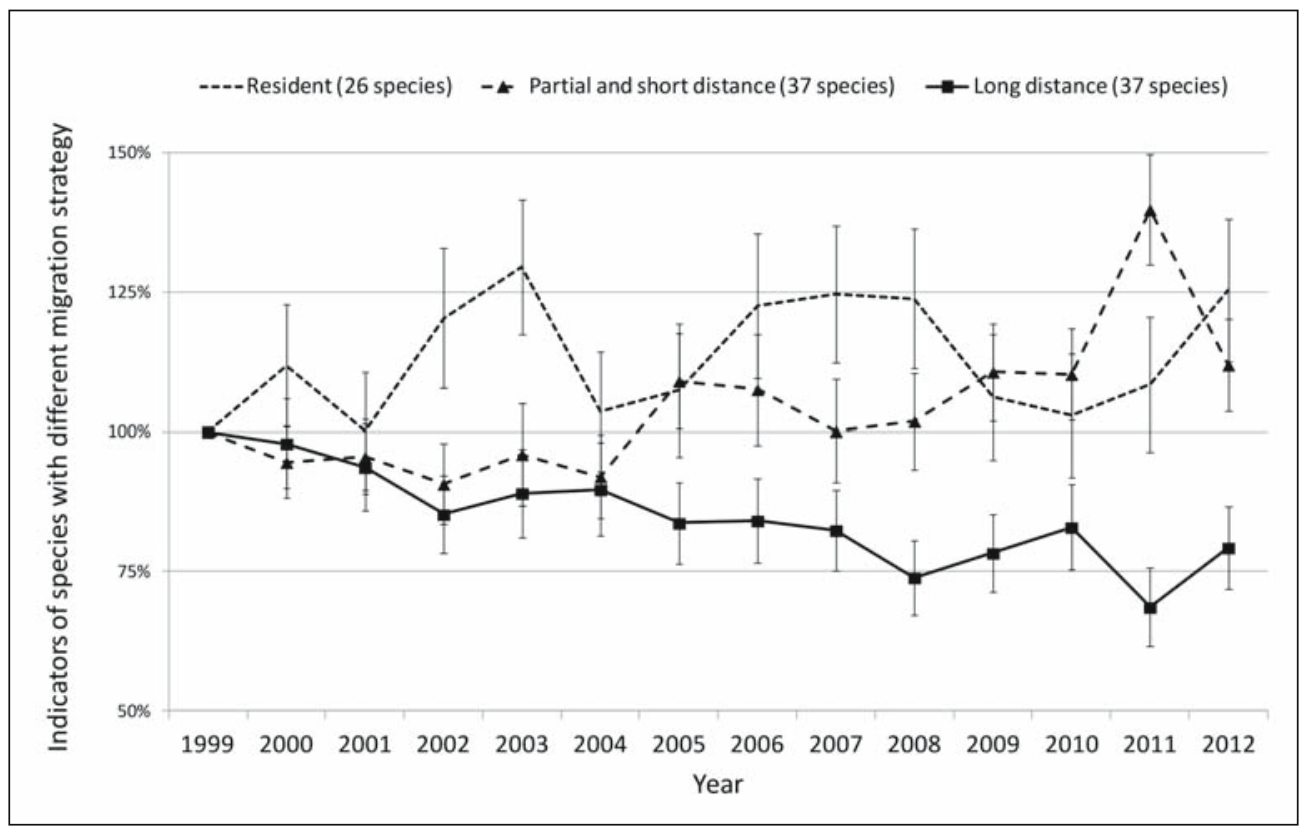

Figure 7. Indicators values of resident, partial and short distance migrant and long distance migrant bird species for the period of 1999-2012 in Hungary. Geometric mean (SE) calculated for each groups on the base of annual imputed index produced by TRIM software. Number of species considered for each groups is given in bracket

7.ábra Állandó, részlegesen/rövidtávon vonuló és a hosszútávon vonuló madárfajok indikátor értékei Magyarországon 1999-2012 között. Mértani átlag, annak hibája (SE) számolva minden csoport esetében a TRIM program éves imputed index értékei alapján. A csoportonként figyelembe vett fajok száma zárójelben megadva 
cies on the basis of migration strategies as: 1- resident species indicator (26 species), 2- partial and short distance migrant species indicator (37 species) and 3- long distance migrant species indicator (37 species) (Figure 7).

In the case of the indicator of long distance migrants there was a significantly decreasing trend (slope $=-0.018(S E=0.003)$, $\left.F=41.083, d f=1,12, P<0.001, R^{2}=0.774\right)$.

Indicators of partial and short distance migrant species showed significantly increasing trends during the studied period (slope $=0.021 \quad(S E=0.006), \quad F=12.597$, $\left.d f=1,12, P=0.004, R^{2}=0.512\right)$ whereas trend of the indicator of resident species was not significant $(F=0.690, d f=1,12, P=0.422)$.

\section{Habitat usage}

We calculated indicators from the annual population indices of the studied species based on the habitat occupancy for 1- farmland habitat (FAH) (41 species), 2- forest habitat (FOH) (21 species) and 3- mixed habitats (MIH) (36 species) (Figure 8a).

The indicator based on all bird species using dominantly farmland in Hungary (FAH) showed significant decrease (slope $=$ -0.011 (SE=0.003), $F=10.801, \quad d f=1,12$, $\left.P=0.007, R^{2}=0.474\right)$.

Indicators of species using forest $(\mathrm{FOH})$ showed significantly increasing trend (slope $=0.031 \quad(S E=0.004), \quad F=57.468$, $d f=1,12, P<0.001, R^{2}=0.827$ ), whereas trend of the indicator of species using mixed habitats (MIH) was not significant $(F=0.258$, $d f=1,12, P=0.620)$.

We calculated indicators using the PECBMS list for Continental part of Europe as well: 1- Farmland Bird Indicator (FBI) (21 species), 2- forest bird indicator values (22 species) and indicators for 'others' species using mixed and/or other habitats (45 species) (Figure 8b).

Farmland Bird Indicator (FBI) based on the PECBMS list showed significant decreasing trend (slope $=-0.020(S E=0.005)$, $\left.F=13.551, d f=1,12, P=0.003, R^{2}=0.530\right)$.

Indicator of forest birds has significant increasing trend (slope $=0.028(S E=0.005)$, $\left.F=32.080, \quad d f=1,12, \quad P<0.001, R^{2}=0.728\right)$. Indicator of species classified as 'others' in the PECBMS list showed no significant trend $(F=2.324, d f=1,12, P=0.153)$.

In the case of farmland habitat indicator (FAH) we calculated three partial indicators based on the habitat preference: 1- farmland birds with preference of farmland habitat (FAFH) (17 species), 2- farmland birds with preference of wetland habitat (FAWH) (11 species), 3- farmland birds with preference of urban and mixed habitat (FAMH) (13 species) (Figure 9).

In the case of indicators based on species preferred the farmland habitat (FAFH) there was a significant decline (slope $=-0.026$ $(S E=0.004), F=53.560, d f=1,12, P<0.001$, $\left.R^{2}=0.817\right)$.

Indicators of farmland species with urban/ mixed habitat preference (FAMH) and indicators of farmland birds with preference of wetland habitats (FAWH) there was no significant trend (FAMH: $F=0.162, d f=1,12$, $P=0.694 ; \quad$ FAWH: $\quad F=0.195, \quad d f=1,12$, $P=0.666)$.

\section{Migration strategy and habitat usage of breeding population}

We calculated specific indicators for considering migration strategy (long distance migrant vs. non long distance migrant) and habitat occupancy (Figure 10).

Indicators of non long distance migrant species with farmland habitat occu- 

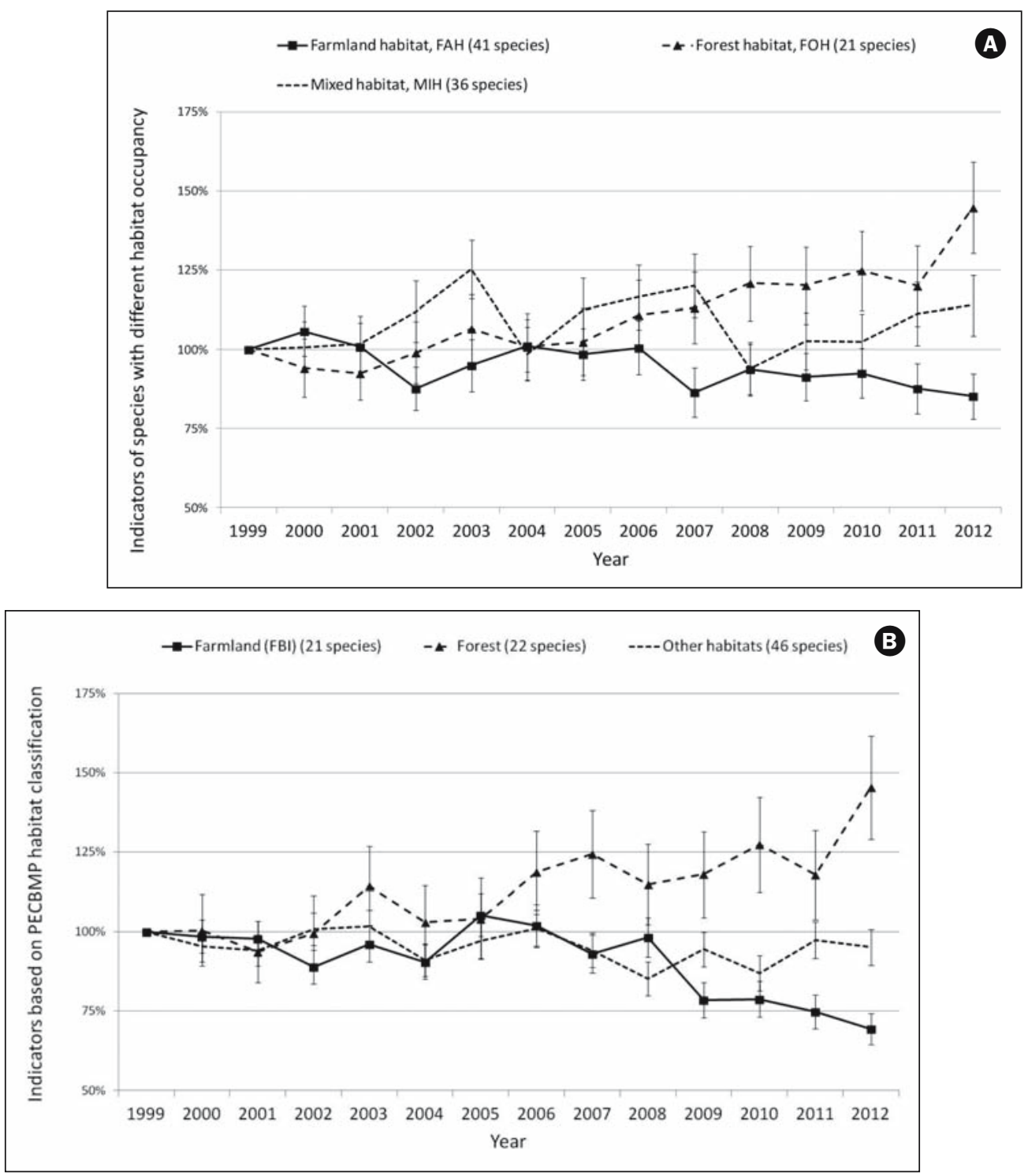

Figure 8. Indicators values of species grouped (A) on the base of habitat occupancy in Hungary (B) on the base EBCC PECBMS list for Continental Europe. Species considered as using mixed habitat if less than $2 / 3$ of the population occurred in the most used main habitat type (urban, farmland, forest, wetland). Species grouped to other habitats when use other habitats than farmland and forest or use several habitats. Geometric mean (SE) calculated for each groups on the base of annual imputed index produced by TRIM software. Number of species considered for each groups is given in bracket

8. ábra Indikátor értékek (A) a magyarországi élőhely használat, és (B) az EBCC PECBMS Kontinentális lista élőhelyi besorolása alapján alkotott fajcsoportok esetében. Amennyiben adott faj hazai állományának kevesebb, mint 2/3-a volt megfigyelve egy adott fő élőhely típusban (urbán, mezőgazdasági, erdei, vizes) a fajt vegyes (mixed) élőhely használatúként volt kezelve. Az EBCC PECBMS esetén az egyéb (others) csoportba azokat a fajokat sorolták, amely nem mezőgazdasági (FBI) vagy erdei, illetve vegyes élőhellyel jellemezhető. Mértani átlag, annak hibája (SE) számolva minden csoport esetében a TRIM program éves imputed index értékei alapján. A csoportonként figyelembe vett fajok száma zárójelben megadva 


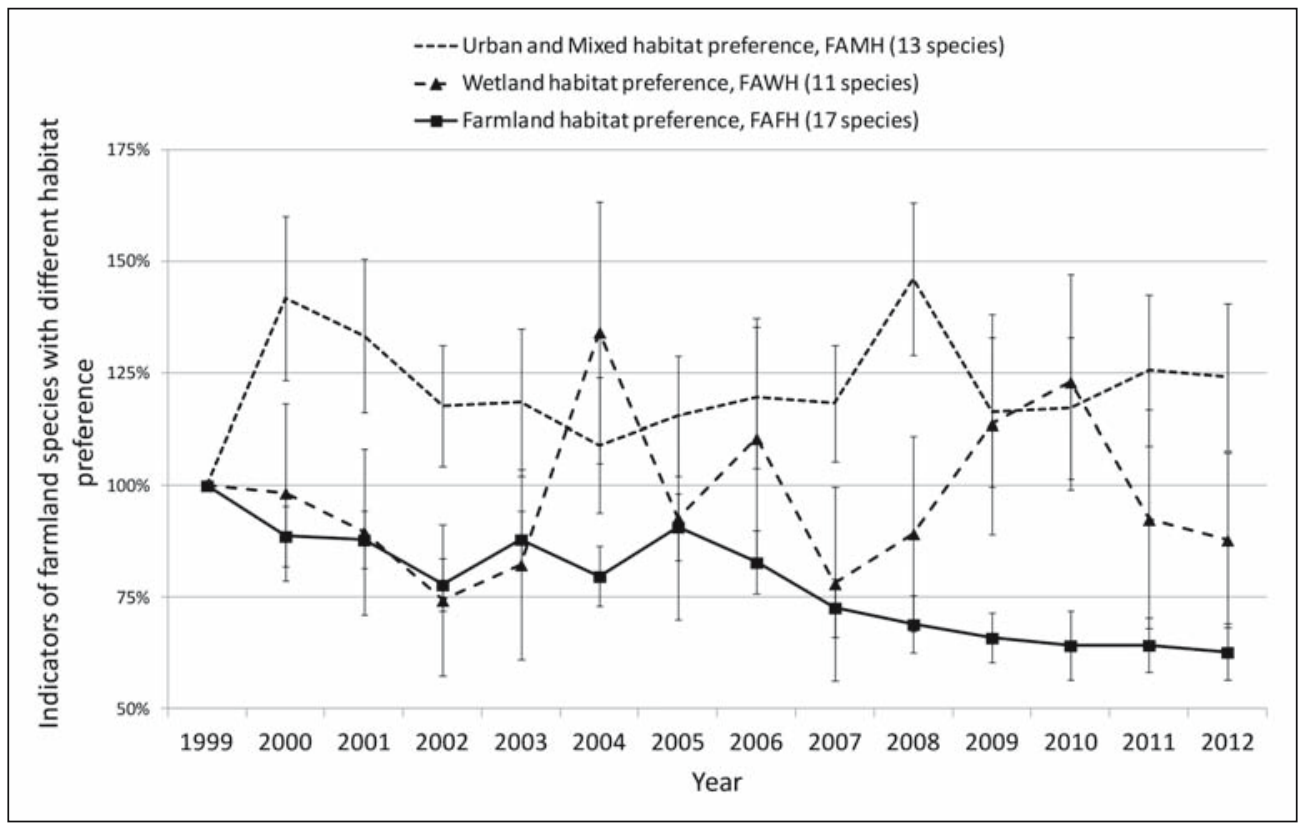

Figure 9. Indicators values of species use mainly the farmland habitat and grouped on the base of habitat preference in Hungary. Species preferred urban and mixed habitat types handled in one group. Geometric mean (SE) calculated for each groups on the base of annual imputed index produced by TRIM software. Number of species considered for each groups is given in bracket

9. ábra Indikátor értékek a Magyarországon a mezőgazdasági élőhelyet használó és különböző élőhely preferenciával (urbán és vegyes, vizes, mezőgazdasági) jellemezhető fajcsoportok esetében. Az urbán és vegyes élőhelyeket preferáló madárfajok egy csoportba sorolva. Mértani átlag, annak hibája (SE) számolva minden csoport esetében a TRIM program éves imputed index értékei alapján. A csoportonként figyelembe vett fajok száma zárójelben megadva

pancy (FANLH) had no significant trend $(F=1.384, d f=1,12, P=0.262)$, whereas indicators of species with similar migration strategy but different habitat occupancy (forest, mixed habitat) had significant increase (FONLH: slope $=0.026(S E=0.005)$, $F=26.203, \quad d f=1,12, \quad P<0.001, \quad R^{2}=0.704$; MINLH: $\quad$ slope $=0.033 \quad(S E=0.012)$, $\left.F=7.036, d f=1,12, P=0.022, R^{2}=0.39\right)(F i$ gure 10a).

Indicators of long distance species with farmland and mixed habitat occupancy showed significant decreasing trends, the level of decrease was higher for indicator of species with mixed habitat occupancy (FALH: slope $=-0.015 \quad(S E=0.005), \quad F=8.856$, $d f=1,12, \quad P=0.012, \quad R^{2}=0.425 ; \quad$ MILH: slope $=-0.028 \quad(S E=0.005), \quad F=29.060$, $d f=1,12, P<0.001, R^{2}=0.708$ ) (Figure 10b).

\section{Indicators based on population trends of the wintering species in Hungary}

From the 57 species for which trends were estimated, we excluded data of seven species (Anser fabalis, Anser albifrons, Anser anser, Haliaeetus albicilla, Accipiter gentilis, Larus ridibundus, Fringilla montifringilla) with very high standard error of the estimated slope $(\mathrm{SE}>0.1)$. 

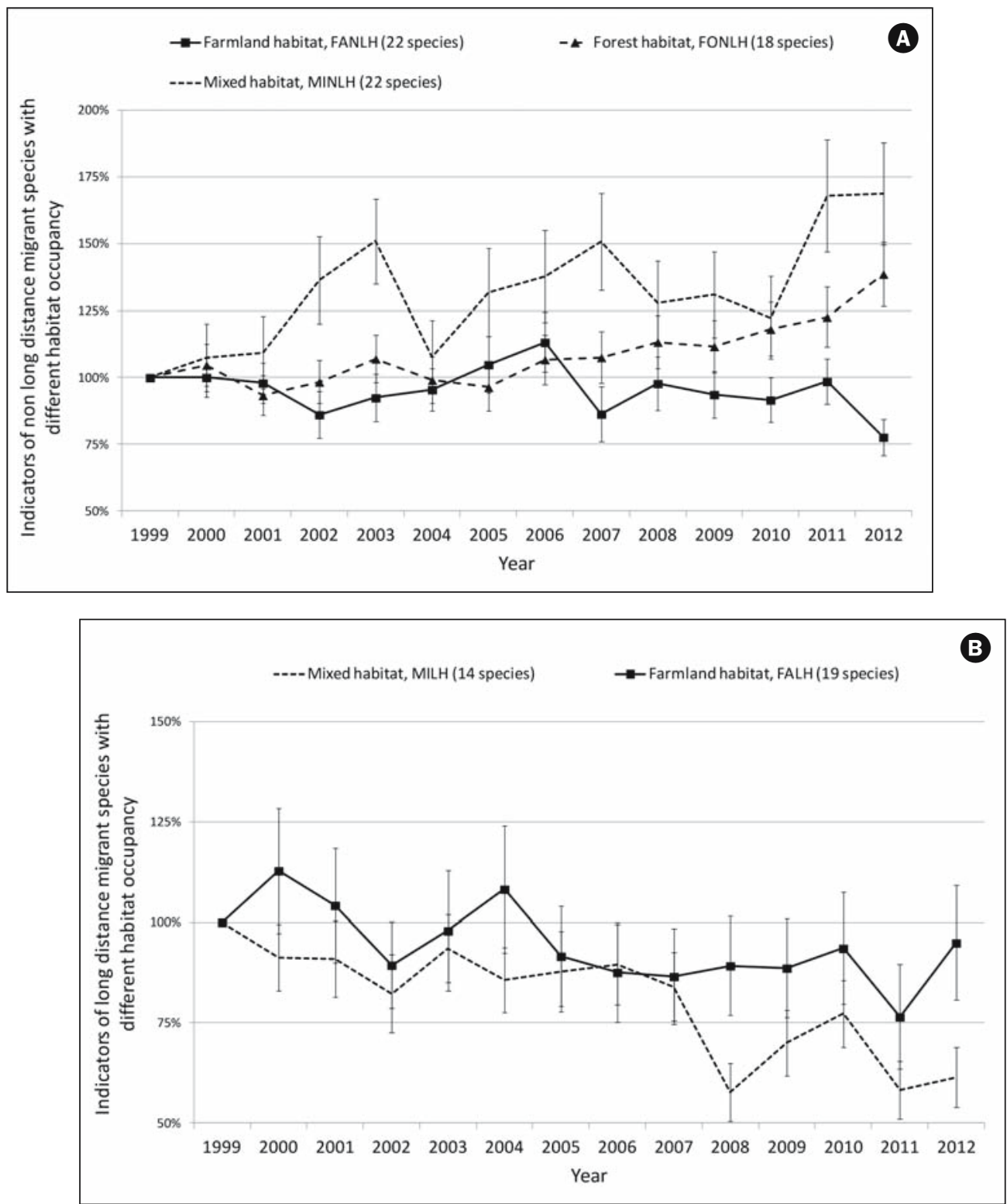

Figure 10. Indicators values of (A) non long distance migrant (resident, partial and short distance) species (B) long distance migrant species grouped on the base of habitat occupancy in Hungary. Species considered as using mixed habitat if less than $2 / 3$ of the population occurred in the most used main habitat type (urban, farmland, forest, wetland). Geometric mean (SE) calculated for each groups on the base of annual imputed index produced by TRIM software. Number of species considered for each groups is given in bracket

10. ábra Indikátor értékek (A) nem hosszútávon vonuló (állandó, részlegesen/rövidtávon vonuló), (B) hosszútávon vonuló fajok különböző élőhelyeket (mezőgazdasági, erdei, vegyes) használó fajcsoportjaik esetében. Amennyiben adott faj hazai állományának kevesebb, mint 2/3-a volt megfigyelve egy adott fő élőhely típusban (urbán, mezőgazdasági, erdei, vizes), a fajt vegyes (mixed) élőhely használatúként volt kezelve. Mértani átlag, annak hibája (SE) számolva minden csoport esetében a TRIM program éves imputed index értékei alapján. A csoportok esetében figyelembe vett fajok száma megadva a zárójelben 
We calculated indicators for wintering species, which wintering population in Hungary formed fully or partly by the Hungarian breeding population, based on the habitat occupancy of the Hungarian breeding population: 1- wintering species with farmland habitat occupancy (WFAH), 2- wintering species with forest habitat occupancy (WFOH), 3- wintering species with mixed habitat occupancy (WMIH) (Figure 11).
Indicators of wintering species with farmland habitat occupancy and mixed habitat occupancy in the breeding season showed significant increasing trends during 20002012, species with mixed habitat occupancy had the strongest increase (WFAH: slope $=$ 0.049 (SE=0.020), $F=6.261, \quad d f=1,11$, $P=0.029, R^{2}=0.363 ; \mathrm{WMIH}$ : slope $=0.101$ ( $S E=0.013), F=60.017, d f=1,11, P<0.001$, $\left.R^{2}=0.845\right)$.

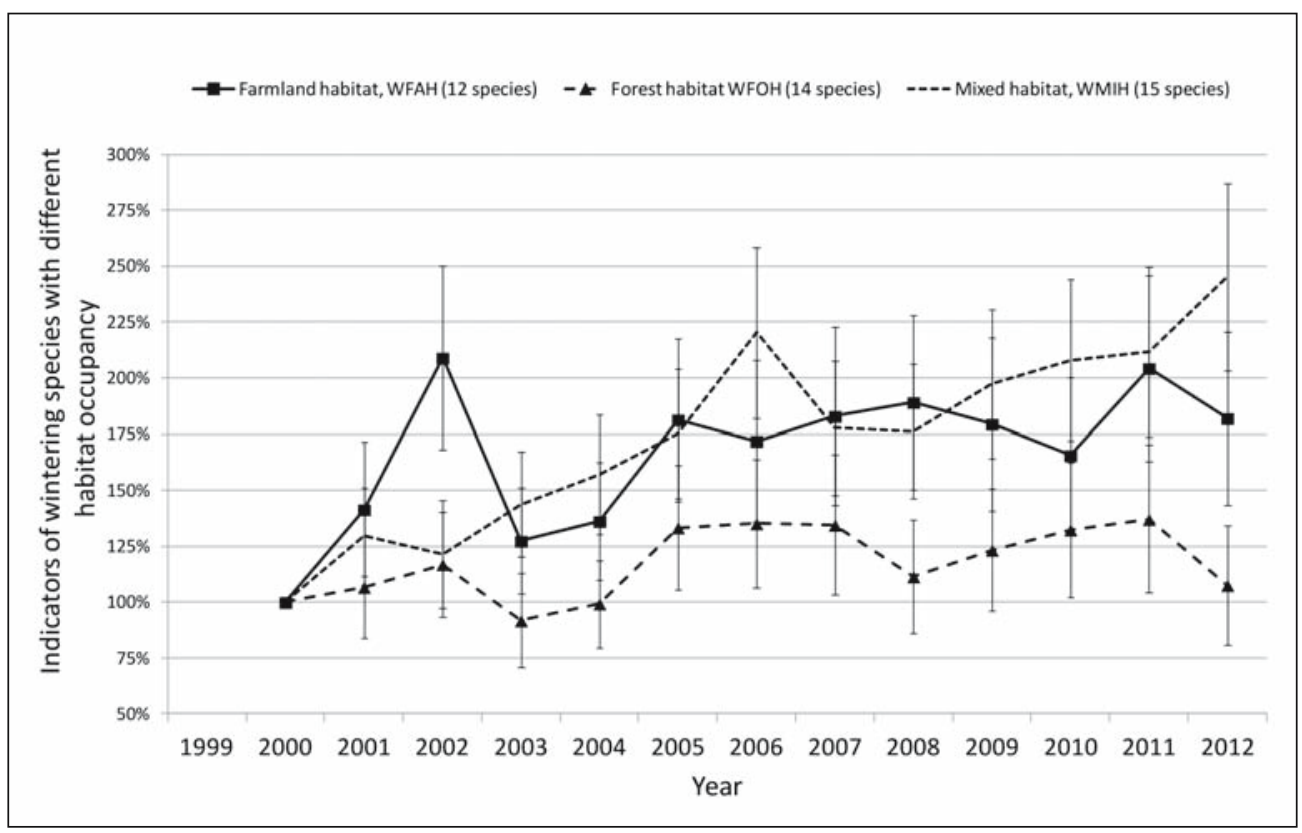

Figure 11. Indicators values of wintering species grouped on the base of habitat occupancy in Hungary in the breeding season. Only wintering species were considered which wintering population formed fully and/or partly by Hungarian breeding population. Species considered as using mixed habitat if less than $2 / 3$ of the population occurred in the most used main habitat type (urban, farmland, forest, wetland) in the breeding season. Geometric mean (SE) calculated for each groups on the base of annual imputed index produced by TRIM software. Number of species considered for each groups is given in bracket

11. ábra A különböző élőhelyeket használó (mezőgazdasági, erdei, vegyes), Magyarországon telelő fajcsoportok indikátor értékei. Csak azon telelő fajok figyelembe véve, amelyek telelő állománya részben vagy egészben a hazai fészkelő állományhoz tartozik. Amennyiben adott faj hazai állományának kevesebb, mint 2/3-a volt megfigyelve egy adott fó élőhely típusban a fészkelési időszakban (urbán, mezőgazdasági, erdei, vizes), a faj vegyes (mixed) élőhely használatúként volt kezelve. Mértani átlag, annak hibája (SE) számolva minden csoport esetében a TRIM program éves imputed index értékei alapján. A csoportok esetében figyelembe vett fajok száma megadva a zárójelben 
Indicator of wintering species with forest habitat occupancy (WFOH) had a weak not significant increasing trend (slope $=0.021$ $(S E=0.011), F=3.853, d f=1,11, P=0.075)$.

\section{Discussion}

The MMM monitoring scheme provided the first relevant information about the frequency of the breeding and wintering species in Hungary, based on quantitative data of representative sampling of the main habitats and covering the entire country. We were able to identify 106 breeding and 57 wintering common species in Hungary, proper for investigating the habitat relation of these species and estimating trends in the scale of the country. The standardised field protocol let to compare frequencies of bird species active during daylight but this protocol was not proper for rare species and for species with high activity at night as most owl or crake species. During the comparison of the estimated frequencies the differences in the detectability of the species (Bibby et al. 2000) has to be considered as well.

We used information based on trend classification by TRIM (increase, stable, decline) to investigate the species trends first because it provides a more conservative and robust approach than considering the value of estimated slope of each investigated species, including species with uncertain trends. We have developed indicators for migratory strategies and habitat occupancy considering these characteristics in combination, using Gregory et al. (2005) approach based on annual population indices produced by the TRIM. These indicators could provide detailed information about groups of species and habitats they use by considering more species than the former analysis based data of species only with trend classification.

Among the 74 breeding species for which direction of the population trends were classified, there was significant difference on the basis of migration strategy among the species. Population decline was significantly more common among the long distance migrant species than among resident, partly or short migrant species. Among the 27 investigated long distance migrant common species in Hungary, more than half had significant decline. There was an opposite situation in the case of the 47 resident, partial and short migrant species, where more than half of them has increasing trend in Hungary. Indicators of migration strategies of common breeding bird species in Hungary, in accordance with the analysis based on species with trend classification, showed continuous decline of the long distance migrant birds and an opposite increase of the partial and short distance species (Figure 7).

Our result is in concordance with several studies which showed the most threatened status of long distance migrant species in Europe comparing with species with other migration strategies (Berthold et al. 1998, Sanderson et al. 2006, Møller 2008, Heldbjerg \& Fox 2008, Jiguet et al. 2009). The decline of the long distance migrants is a general phenomenon in Europe and presumably the climate change has an important role (Both \& Visser 2001, Both et al. 2006) among others as habitat change, agricultural intensification. Opposite trends of partial and short distance migrant species comparing to long distance migrant species in Hungary support the importance of climate change related issues to explain the found processes (Jiguet et al. 2010). The observed trends are usually a combination of breeding and non-breeding area effects, which both 
affected by climate change (Morrison et al. 2013).

Monitoring of common bird species with formal sampling protocol let us to monitor not only the given species but the condition of habitats these species use for breeding/ foraging (Bibby 1999, Gregory et al. 2005). One of the main purpose of the MMM like common bird monitoring schemes in Europe (e.g. Gregory et al. 1996, Del Moral et al. 2010, Jiguet et al. 2012) is to use groups of species as indicators of the main habitats, for which species selection has a crucial importance (Gregory et al. 2005). In the case of the most common bird species in Europe, the classification of species in relation to the habitat to which the species highly related as Tucker and Evans (1997) present, allow to form groups for indicators. However, investigation of the list of species considered as indicators of a given habitat in a given country or region is needed using quantitative data over the expert judgement (see Gregory \& van Strien 2010), because of the differences of species habitat use among these geographical areas (frequency, importance of the given habitat type in nesting/foraging which could differ among countries)

In our work, we used the CORINE land cover GIS database of Hungary (Büttner \& Maucha 2006) to investigate the habitat preference and habitat occupancy of the most common breeding species in Hungary on the base of the observation data of MMM at known localities between 1999 and 2012. There was no similar investigations in Hungary before, the existing general overview of Hungarian breeding species (Haraszthy 1998), contains information about habitat related information, based on studies which used different methods and carried out on varying spatial and temporal scale. The spatial resolution of the used CORINE habitat database let us to investigate mainly at the level of landscape the relation of the given species to the four main habitat types (urban, farmland, forest, wetland). Estimating the relative densities of the given species in the main studied habitat types with knowing the extension of these habitats in Hungary allowed to estimate the distribution of the Hungarian population of these species among these main habitats which let us to investigate the habitat occupancy of these species.

Investigation of habitat occupancy of common species showed the large importance of farmland habitats on breeding fauna, more than $40 \%$ of the species dominantly use these habitats for nesting/foraging. The classification of habitat preference by comparing the relative densities of the species in the studied main habitat types, expecting the largest density in the preferred habitat (Brown 1969, Fretwell \& Lucas 1970), allow to investigate in more detail the relation of the given species to the studied habitats. This kind of approach of habitat preference admitted that e.g. the most Acrocephalus species preferred the wetland habitat, however at the same time dominant part of the population use the farmland habitat in Hungary. The spatial resolution of the used CORINE land cover is coarse, and it is not possible to identify the smaller than (1-4 ha) size wetland patches in the farmland areas, which can explain the 'contradiction'. However, these small patches of wetland habitat are important part of the farmland landscape in Hungary, management and using (e.g. melioration) is highly related to the practice in this habitat in Hungary which suggests to consider these species for indicator of farmland habitat as well.

Considering the habitat occupancy of the studied species altogether with habitat preference (Chamberlain \& Fuller 1999), using es- 
timations based on large relevant dataset, allow us to verify the internationally suggested list of indicators (PECBMS) for the region of Hungary and to develop country specific new indicators of habitats. In the case of the list of farmland bird indicator (FBI) of the PECBMS (22 species), we found that the FBI largely consider species with obvious usage of farmland habitats in Hungary. We identified two species only in the FBI list (Streptopelia turtur and Emberiza citrinella) where nor the habitat occupancy and nor the habitat preference did not relate dominantly to farmland habitat in Hungary. Among the 44 species, which breeding populations in Hungary dominantly use the farmland habitat, we identified three groups on the base of the habitat preference (farmland, wetland, urban and mixed habitat). On the base of these groups, we developed specific indicators of the farmland habitats which allow to use country specific farmland bird indicators, which could indicate processes in the farmland in more detail, than using only one simple indicator. Our work let us to investigate the species list of forest and mixed habitat indicators of PECBMS and to develop country specific list for these indicators as well.

Significant declining population trends were more common among those breeding species, which dominantly use the farmland habitat in Hungary (Figure 4). More than half of farmland species with trend classification had significant decline whereas in the case of species with forest habitat occupancy, more than $2 / 3$ of species had significant increasing trend. We have found the same direction in the case of indicators based on habitat occupancy. The farmland birds had significant declining trend and the birds of forest had significant increasing trend. Our results are similar as found on the level of Europe (Gregory et al. 2007, Greg- ory \& van Strien 2010). This general pattern can be observed in most European countries, but the detailed trends and the underlying causes can be very different (Wretenberg et al. 2006, Reif et al. 2008). Considering the species selection of the PECBMS for habitat indicators yield similar results as habitat indicators based on classification of our habitat occupancy data which considered more species. The decline of farmland species was more steep using PECBMS species list (FBI) comparing to indicators based on habitat occupancy (FAH) in Hungary. In the case of indicators of the farmland habitat based on habitat occupancy data (FAH) more species (41 species) were considered than in the case of farmland bird indicator (FBI) of the PECBMS (21 species) and FAH formed by species with different habitat preference which condition we need to consider. We developed three separate indicators for species dominantly use the farmland habitat in Hungary on the base of the habitat preference. Indicator of farmland bird species with preference of farmland habitat (FAFH) showed steep significant decline, whereas indicators of farmland birds with preference of wetland and urban and mixed habitat did not show declining trends (Figure 9). Our results showed that behind the decline of the farmland birds the farmland related effects could play the main role.

Our results suggest that in Hungary the indicator based on species with habitat preference and occupancy of farmland habitat (FAFH) could be the most adequate indicator to follow the condition of farmland habitat in Hungary and similar selection criteria could be adequate for forest habitat (FOH). All investigated indicators of farmland birds (FBI, FAH, FAFH) showed that declining trend has started after joining of Hungary to the EU in 2004. 
The increase of forest birds, indicated by large number of these species with increasing trends and the increasing trends of indicators of forest birds (Figure 4, 8) very probably indicate the extension of the areas of forest in Hungary. The forested area increased with 7\% in Hungary during 2000-2012 (www.ksh.hu) mainly by acacia and poplar afforestation in areas used for farming formerly. The afforestation could explain the decrease of several farmland species as well (Butler et al. 2010). The observed pattern is very similar to found in the Czech Republic (Reif et al. 2007).

To interpret the found population trends we need to consider the migratory strategy of these species above the habitat usage because of the opposite processes of long distance versus non long distance migrant species in Hungary. Among non long distance migrants, for which the increase were the commonest trend, species with farmland habitat occupancy were not able to benefit the same level of the potentially climate related positive changes (Jiguet et al. 2010) as species with forest and mixed habitat occupancy. Only the $22 \%$ of species which use dominantly the farmland habitat had significant increase, while the declining and stable trends are more common (Figure 5). Indicators combining migration strategy and habitat occupancy, in concordance with analysis of trend classification, showed that indicators of non long distance migrant, which dominantly use the forest and the mixed habitat had significant increase but for species using farmland there was no similar trend (Figure 10a). Populations of non long distance migrant species, using dominantly the farmland habitat, were not able to realise the benefit of climate related changes, which indicate the habitat related adverse effects independently from the influence of the migration strategy.
Indicators of long distance species which use dominantly farmland and mixed habitat showed significant decline in both of these habitats.

The MMM provided the first relevant information about trends of wintering common bird species in Hungary. Among the investigated 57 species, the trends were classified for 28 species. Nearly $2 / 3$ of the wintering species in Hungary had significant increasing trend and only 4 species had decreasing trends. The available data did not show marked difference in the distribution of these trends between wintering population of species formed mainly from Hungarian populations and wintering population of species formed partly or fully from foreign populations. Based on the existing trend data, the wintering condition probably became more favourable than adverse in Hungary during 2000-2012. Indicators of wintering species, grouped on the basis of habitat occupancy of the Hungarian population in the breeding season showed contradictory results. Indicators of species with farmland and mixed habitat occupancy had increasing trend during the wintering whereas indicators of forest species there was no obvious trend. Indicators of the farmland species had decreasing trend during the breeding season in Hungary and behind the opposite trend of the indicator of farmland habitat during the wintering season, one can expect the influence of the foreign wintering populations, mainly arrive from northern, northeast and east directions to Hungary. These large areas probably covered mainly with non EU member countries, however we have limited information about origin and size of these populations.

We pointed out that long distance migrant bird species had strong decreasing trends in Hungary and very probable in the entire Pannonian biogeographical region, based on the 
Hungarian common bird monitoring scheme (MMM), which is the longest running country-wide monitoring using formal sampling design with representative data for the main habitats in Central-Eastern Europe. We showed that partial and short migrant species has increasing trends, in accordance with expectation of effects of climate change (Jiguet et al. 2010), which admitted by the increasing trend of common wintering species in Hungary. Beside the climate related effects, that habitat related influences are important factors as well behind the found processes. We pointed out that farmland birds had declining trend, which trend became more obvious since the joining of Hungary to the EU.

Our work show, that negative changes in the farmland habitat could influence bird species nesting/foraging mainly in this habitat independently from their migration strategies. Our results show the increasing importance to monitor the effects of Common Agricultural Policy (CAP) and the efficiency of the mitigation of the adverse effect of the CAP in the frame of Agri-Environmental Schemes (AES) (Butler et al. 2010) in Hungary as the modelling of future land-use changes in this region suggest further declines of farmland birds (Schoelfield et al. 2011). In concordance with Both et al. (2010), our results suggest that long distance

\section{References}

Báldi, A., Moskát, Cs. \& Szép, T. 1997. Nemzeti Biodiverzitás-monitorozó Rendszer IX. Madarak [National biodiversity monitoring system IX. Birds]. - Magyar Természettudományi Múzeum, Budapest (In Hungarian)

Balmford, A., Green, R. E. \& Jenkins, M. 2003. Measuring the changing state of nature. - TRENDS in Ecology \& Evolution 18: 326-330. doi: 10.1016/ S0169-5347(03)00067-3

Berthold, P., Fiedler, W., Schlenker, R. \& Querner, U. 1998. 25-year study of the population development of Central European songbirds: a general migrant species are in most severe condition in highly seasonal habitats. Our investigations of habitat occupancy and preference of the common bird species let us to develop indicators on the base migration strategy and habitat usage of common birds to provide regular data about condition of group of species and their habitat in Hungary and the Pannonian region. The MMM database provide unique opportunity for further investigations of several species, habitats and area specific in a part of Europe where this kind of information is more than rare yet, as several former studies done (Nagy \& Szép 2009, Mag et al. 2011, Seres et al. 2012).

\section{Acknowledgements}

We thank to the more than 1000 voluntary observers and observers of National Parks for very valuable contribution in the MMM. We thank the RSPB for the financial support of the first 5 years of the MMM, the EBCC for help developing sampling design, the ministry responsible for nature protection in Hungary (KVVM, VM) for providing partial financial support and MME/BirdLife Hungary for providing logistical and financial support for the organisation of the work since the beginning.

decline, most evident in long-distance migrants. Naturwissenschaften 85: 350-353.

Bibby, C. J. 1999. Making the most of birds as environmental indicators. - Ostrich 70: 81-88.

Bibby, C. J., Hill, D. A., Burgess, N. D. \& Mustoe, S. 2000. Bird Census Techniques, second ed., Academic Press, London UK

Both, C. \& Visser, M. E. 2001. Adjustment to climate change is constrained by arrival date in a long-distance migrant bird. - Nature 411: 296-298. doi: $10.1038 / 35077063$ 
Both, C., Bouwhuis, S., Lessells, C. M. \& Visser, M. E. 2006. Climate change and population declines in a long distance migratory bird. - Nature 441: 81-83. doi: 10.1038/nature04539

Both, C., van Turnhout, C. A. M., Bijlsma, R. G., Siepel, H., van Strien, R. J. \& Foppen, R. P. B. 2010. Avian population consequences of climate change are most severe for long-distance migrants in seasonal habitats. - Proceedings of the Royal Society B 277: 1259-1266. doi: 10.1098/rspb.2009.1525

Brown, J. L. 1969. Buffer effect and productivity in tit populations. - American Naturalist 103: 347-354.

Butchart, S. H. M., Walpole, M., Collen, B., van Strien, A., Scharlemann, J. P. W., Almond, R. E. A., Baillie, J. E. M., Bomhard, B., Brown, C., Bruno, J., Carpenter, K. E., Carr, G. M., Chanson, J., Chenery, A. M., Csirke, J., Davidson, N. C., Dentener, F., Foster, M., Galli, A., Galloway, J. N., Genovesi, P., Gregory, R. D., Hockings, M., Kapos, V., Lamarque, J.-F., Leverington, F., Loh, J., McGeoch, M. A., McRae, L., Minasyan, A., Hernández Morcillo, M., Oldfield, T. E. E., Pauly, D., Quader, S., Revenga, C., Sauer, J. R., Skolnik, B., Spear, D., Stanwell-Smith, D., Stuart, S. N., Symes, A., Tierney, M., Tyrrell, T. D., Vié, J-C. \& Watson, R. 2010. Global Biodiversity: Indicators of Recent Declines. - Science 328: 1164-1168. doi: 10.1126/ science. 1187512

Butler, S. J., Boccaccio, L., Gregory, R. D., Vorisek, P. \& Norris, K. 2010. Quantifying the impact of landuse change to European farmland bird populations. - Agriculture Ecosystems and Environment 137: 348-357. doi: 10.1016/j.agee.2010.03.005

Büttner, G., Maucha, G. 2006. The thematic accuracy of Corine land cover 2000. Assessment using LUCAS (land use/cover area frame statistical survey). - EEA Technical Report No 7/2006. ISSN 1725-2237.

Chamberlain, D. E. \& Fuller, R. J. 1999. Density-dependent habitat distribution in birds: issues of scale, habitat definition and habitat availability. - Journal of Avian Biology 30: 427-436. doi: $10.2307 / 3677015$

Csörgő, T., Karcza, Zs., Halmos, G., Magyar, G., Gyurácz, J., Szép, T., Bankovics, A., Schmidt, A. \& Schmidt, E. (eds.) 2009. Magyar Madárvonulási Atlasz [Hungarian Bird Migration Atlas]. - Kossuth Kiadó, Budapest (In Hungarian with English Summary)

Del Moral, J. C., Bermejo, A., Molina, B., Escandell, V. \& Palomino, D. (eds.) 2010. SEO/BirdLife Monitoring Programs in 2008. - SEO/BirdLife, Madrid

Fekete, G., Molnár, Zs. \& Horváth, F. (eds.) 1997. Nemzeti Biodiverzitás-monitorozó Rendszer II.
A magyarországi élőhelyek leírása, határozója és a Nemzeti Élőhely-osztályozási Rendszer [National biodiversity monitoring system II. List of habitats in Hungary and the national habitat classification system]. - Magyar Természettudományi Múzeum, Budapest (In Hungarian)

Fretwell, S., Lucas, H. J. 1970. On territorial behavior and other factors influencing habitat distribution in birds. I. Theoretical Development. - Acta Biotheoretica 19: 16-36.

Gibbons, D. W. 2000. Development of Pan-European breeding bird monitoring. - Ring 22: 25-33.

Greenwood, J. J. D. 2007. Citizens, science and bird conservation. - Journal of Ornithology 148: 77124. doi: 10.1007/s10336-007-0239-9

Gregory, R. D., Willis, S. G., Jiguet, F., Voříšek, P., Klvaňová, A., van Strien, A., Huntley, B., Collingham, Y. C., Couvet, D. \& Green, R. E. 2009. An indicator of the impact of climatic change on European bird populations. - PLoS ONE 4: e4678 doi:10.1371/journal.pone.0004678

Gregory, R. D., Bashford, R. I., Balmer, D. E., Marchant, J. H., Wilson, A. M. \& Baillie, S. R. 1996. The breeding bird survey 1994-1995. - BTO, Thetford

Gregory, R. D., Noble, D., Field, R., Marchant, J., Raven, M. \& Gibbons, D. W. 2003. Using birds as indicators of biodiversity. - Ornis Hungarica 12-13: 11-24.

Gregory, R. D. \& van Strien, A. 2010. Wild bird indicators: using composite population trends of birds as measures of environmental health. - Ornithological Science 9: 3-22.

Gregory, R. D., van Strien, A., Vorisek, P., Gmelig Meyling, A. W., Noble, D. G., Foppen, R. P. B. \& Gibbons, D. W. 2005. Developing indicators for European birds. - Philosophical Transactions of the Royal Society B-Biological Sciences B. 360: 269-288. doi: 10.1098/rstb.2004.1602

Gregory, R. D., Vorisek P., van Strien, A., Meyling, A. W. G., Jiguet, F., Fornasari, L., Reif, J., Chylarecki, P. \& Burfield, I. J. 2007. Population trends of widespread woodland birds in Europe. - Ibis 149: 78-97.

Gregory, R. D., Vořišek, P., Noble, D. G., van Strien, A., Klvaňová, A., Eaton, M., Meyling, A. W. G., Joys, A., Foppen, R. P. B. \& Burfield, I. J. 2008. The generation and use of bird population indicators in Europe. - Bird Conservation International 18: S223-S244. doi: 10.1017/S0959270908000312

Haraszthy, L. (ed.) 1998. Magyarország fészkelő madarai [Breeding birds of Hungary]. - Mezőgazda Kiadó, Budapest (In Hungarian)

Heldbjerg, H. \& Fox, T. 2008 Long-term population declines in Danish trans-Saharan migrant birds. Bird Study 55: 267-279. 
Jiguet, F., Devictor, V., Julliard, R. \& Couvet, D. 2012. French citizens monitoring ordinary birds provide tools for conservation and ecological sciences. - Acta Oecologica 44: 58-66. doi: 10.1016/j. actao.2011.05.003

Jiguet, F., Gregory, R., D., Devictor, V., Green, R., E., Vorisek, P., van Strien, A. \& Couvet, D. 2010. Population trends of European common birds are predicted by characteristics of their climatic niche. - Global Change Biology 16: 497-505. doi: 10.1111/j.1365-2486.2009.01963.x

Julliard, R., Clavel, J., Devictor, V., Jiguet, F. \& Couvet, D. 2006. Spatial segregation of specialists and generalists in bird communities. - Ecology Letters 9: 1237-1244. doi: 10.1111/j.14610248.2006.00977.x

Julliard, R., Jiguet, F. \& Couvet, D. 2003. Common birds facing global changes: what makes a species at risk? - Global Change Biology 10: 148-154. doi: 10.1111/j.1365-2486.2003.00723.x

Mag, Zs., Szép, T., Nagy, K. \& Standovár, T. 2011. Modelling forest bird community richness using CORINE land cover data: a study at the landscape scale in Hungary. - Community Ecology 12: 241248. doi: 10.1556/ComEc.12.2011.2.13

McCullagh, P. \& Nelder, J. A. 1989. Generalized linear models, $2^{\text {nd }}$ ed. - Chapman \& Hall, London

Møller, A. P. 2008. Flight distance and population trends in European breeding birds. - Behavioral Ecology 19: 1095-1102. doi: 10.1093/beheco/arn103

Morrison, C. A., Robinson, R. A., Clark, J. A., Risely, K. \& Gill, J. A. 2013. Recent population declines in Afro-Palaearctic migratory birds: the influence of breeding and non-breeding seasons. - Diversity and Distributions 19: 1051-1058. doi: 10.1111/ ddi. 12084

Nagy, Sz., Nagy, K. \& Szép, T. 2009. Potential impact of EU accession on common farmland bird populations in Hungary. - Acta Ornithologica 44: 37-44. doi: 10.3161/000164509X464867

Pannekoek, J. \& van Strien, A. J. 2001. TRIM 3 Manual. Trends and Indices for Monitoring Data. - Research paper no. 0102 .

Reif, J., Vorisek, P., Stastny, K., Bejcek, V. \& Petr, J. 2007. Population increase of forest birds in the Czech Republic between 1982 and 2003. - Bird Study 54:248-255.

Reif, J., Vorisek, P., Stasny, K., Bejcek, V. \& Petr, J. 2008. Agricultural intensification and farmland birds: new insights from a central European country. - Ibis 150: 596-605. doi: 10.1111/j.1474919X.2008.00829.x
Sanderson, F. J., Donald, P. F., Pain, D. J., Burfield, I. J. \& van Bommel, F. P. J. 2006. Long-term population declines in Afro-Palearctic migrant birds. - Biological Conservation 131: 93-105. doi: 10.1016/j.biocon.2006.02.008

Scholefield, P., Firbank, L., Butler, S., Norris, K., Jones, L. M. \& Petit, S. 2011. Modelling the European farmland bird indicator in response to forecast land-use change in Europe. - Ecological Indicators 11: 46-51. doi: 10.1016/j.ecolind.2009.09.008

Seress, G., Bókony, V., Pipoly, I., Szép, T., Nagy, K. \& Liker, A. 2012. Urbanization, nestling growth and reproductive success in a moderately declining House Sparrow population. - Journal of Avian Biology 43: 403-414. doi: 10.1111/j.1600048X.2012.05527.x

Szép, T. \& Waliczky, Z. 1993. Ritka és telepesen fészkelő madarak monitoring programja [Monitoring of rare and colonial bird species]. - Magyar Madártani és Természetvédelmi Egyesület, Budapest (In Hungarian)

Szép, T. \& Gibbons, D. 2000. Monitoring of common breeding birds in Hungary using a randomised sampling design. - Ring 22: 45-55.

Szép, T., Nagy, K. 2002. Mindennapi Madaraink Monitoringja (MMM) 1999-2000 [Monitoring of common bird (MMM) 1999-2000]. - MME/BirdLife Hungary, Budapest (In Hungarian with English Summary)

Tucker, G. M. \& Evans, M. I. 1997. Habitats for birds in Europe: a conservation strategy for the wider environment. - BirdLife International, Cambridge

van Strien, A. J., Pannekoek, J. \& Gibbons, D. W. 2001. Indexing European bird population trends using results of national monitoring schemes: a trial of a new method. - Bird Study 48: 200-213.

Waliczky, Z. 1991. Beszámoló az énekesmadarak monitoring típusú állományfelmérésének első két évéröl [Report on the point-count of passerine-birds, for its first two years]. - Aquila 98: 163-168. (In Hungarian with English Summary)

Wretenberg, J., Lindstroem, A., Svensson, S., Thierfelder, T. \& Paert, T. 2006. Population trends of farmland birds in Sweden and England: similar trends but different patterns of agricultural intensification. - Journal of Applied Ecology 43(6): 1110-20. doi: 10.1111/j.1365-2664.2006.01216.x

Yoccoz, N. G., Nichols, J. D. \& Boulinier, T. 2001. Monitoring of biological diversity in space and time. - TRENDS in Ecology \& Evolution 16: 446-453. doi: 10.1016/S0169-5347(01)02205-4 
Table 1. Mean frequency (SE), type of trend with slope (SE) values, habitat occupancy, preference, EBCC PECBMS list for Continental Europe habitat classification and migration strategy of the most common 106 bird species (frequency larger than 5\%) during the breeding season between 1999-2012 in Hungary on the base of MMM data. Mean frequency (SE) estimated from the annual frequencies $(n=14)$. Trend type: $(-2)$ steep decline, $(-1)$ moderate decline, (0) stable, (1) moderate increase, (+2) strong increase, (u) uncertain trend. Habitat categories of habitat usage, habitat preference and PECBMS (EBCC): (1) urban, (2) farmland, (3) forest, (4) wetlands, (5) mixed/others. Migration strategies: (1) resident, (2) partial and short distance migrant, (3) long-distance migrant ( ${ }^{*}: \mathrm{P}<0.05,{ }^{* *}$ : $\mathrm{P}<0.01$, \# uncertain migration strategy)

1. táblázat A leggyakoribb 106 fészkelő madárfaj átlagos gyakorisága, átlag hibája (SE), a trend típusa és az átlagos éves változás értéke, átlag hibája (SE), élőhely használata, élőhely preferenciája, EBCC PECBMS Kontinentális Európa élőhely klasszifikációja és a vonulási stratégiája a Magyarországon az MMM keretében, a fészkelési időszakban 1999 és 2012 között gyűjtött adatok alapján. Az átlagos gyakoriság az évenként számolt gyakorisági értékek alapján számolva ( $n=14)$. Trend típus: $(-2)$ erős csökkenés, $(-1)$ mérsékelt csökkenés, $(0)$ stabil, (1) mérsékelt növekedés, (+2) erős növekedés, (u) bizonytalan trend. Az élőhely használat, preferencia és a PECBMS (EBCC) besorolásnál használt élőhely típusok: (1) urbán, (2) mezőgazdasági, (3) erdei, (4) vizes élőhely, (5) vegyes/egyéb. Vonulási stratégiák: (1) állandó, (2) részlegesen, rövidtávon vonuló, (3) hosszútávon vonuló (*: $P<0.05$, **: $P<0.01$, \# bizonytalan a vonulási stratégiájú)

\begin{tabular}{|c|c|c|c|c|c|c|c|c|c|c|}
\hline \multirow[t]{2}{*}{ Species } & \multicolumn{2}{|c|}{ 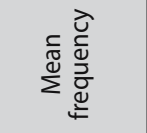 } & \multicolumn{4}{|c|}{ Trend } & \multicolumn{3}{|c|}{ Habitat } & \multirow{2}{*}{$\begin{array}{c}\stackrel{\substack{0 \\
\frac{0}{0}}}{.00} \\
\text { strategy } \\
\end{array}$} \\
\hline & $(\%)$ & (SE) & type & slope & (SE) & & usage & pref. & EBCC & \\
\hline Phalacrocorax carbo & 7.8 & 0.8 & $\mathrm{u}$ & 0.041 & 0.076 & & 4 & 4 & & 2 \\
\hline Botaurus stellaris & 6.8 & 1.1 & $\mathrm{u}$ & -0.075 & 0.058 & & 2 & 4 & & 2 \\
\hline Nycticorax nycticorax & 7.6 & 1.0 & $\mathrm{u}$ & -0.065 & 0.059 & & 4 & 4 & & 3 \\
\hline Egretta alba & 19.7 & 2.2 & 2 & 0.242 & 0.064 & $* *$ & 2 & 4 & & 2 \\
\hline Ardea cinerea & 35.0 & 1.5 & 2 & 0.142 & 0.031 & $* *$ & 2 & 4 & 5 & $\#$ \\
\hline Ardea purpurea & 5.6 & 0.4 & $\mathrm{u}$ & 0.026 & 0.059 & & 5 & 4 & & 3 \\
\hline Ciconia ciconia & 30.2 & 1.1 & $\mathrm{u}$ & -0.010 & 0.021 & & 2 & 4 & 2 & 3 \\
\hline Anser anser & 5.8 & 1.1 & $\mathrm{u}$ & 0.095 & 0.147 & & 4 & 4 & & 2 \\
\hline Anas platyrhynchos & 44.9 & 1.7 & $\mathrm{u}$ & 0.026 & 0.014 & & 5 & 4 & 5 & 2 \\
\hline Circus aeruginosus & 43.0 & 1.2 & $\mathrm{u}$ & -0.032 & 0.018 & & 2 & 4 & 5 & 3 \\
\hline Circus pygargus & 5.1 & 0.6 & $\mathrm{u}$ & 0.058 & 0.240 & & 2 & 2 & & 3 \\
\hline Accipiter gentilis & 6.4 & 0.4 & $\mathrm{u}$ & -0.008 & 0.080 & & 5 & 3 & & 1 \\
\hline Accipiter nisus & 12.6 & 0.9 & $\mathrm{u}$ & 0.022 & 0.062 & & 5 & 3 & 3 & 1 \\
\hline Buteo buteo & 80.3 & 1.0 & 0 & 0.005 & 0.011 & & 2 & 5 & 5 & 1 \\
\hline Falco tinnunculus & 30.0 & 1.3 & $\mathrm{u}$ & -0.021 & 0.023 & & 2 & 2 & 2 & 2 \\
\hline Falco subbuteo & 8.0 & 0.6 & $\mathrm{u}$ & 0.167 & 0.083 & & 2 & 1 & & 3 \\
\hline Perdix perdix & 5.4 & 0.7 & -1 & -0.107 & 0.040 & $* *$ & 2 & 2 & 2 & 1 \\
\hline Coturnix coturnix & 44.4 & 1.4 & -1 & -0.064 & 0.011 & $* *$ & 2 & 2 & & 2 \\
\hline Phasianus colchicus & 90.8 & 0.7 & 0 & -0.001 & 0.006 & & 2 & 2 & 5 & 1 \\
\hline Fulica atra & 10.5 & 0.9 & $\mathrm{u}$ & 0.057 & 0.034 & & 5 & 4 & 5 & 2 \\
\hline Vanellus vanellus & 36.5 & 1.2 & 0 & 0.003 & 0.013 & & 2 & 2 & 2 & 2 \\
\hline Tringa totanus & 10.8 & 0.8 & -1 & -0.062 & 0.030 & * & 2 & 4 & 5 & 2 \\
\hline Tringa glareola & 5.7 & 1.1 & $\mathrm{u}$ & -0.093 & 0.220 & & 2 & 2 & & 3 \\
\hline
\end{tabular}




\begin{tabular}{|c|c|c|c|c|c|c|c|c|c|c|}
\hline \multirow[t]{2}{*}{ Species } & \multicolumn{2}{|c|}{ 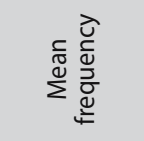 } & \multicolumn{4}{|c|}{ Trend } & \multicolumn{3}{|c|}{ Habitat } & \multirow{2}{*}{ 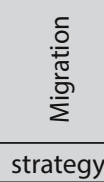 } \\
\hline & (\%) & (SE) & type & slope & (SE) & & usage & pref. & EBCC & \\
\hline Larus ridibundus & 19.2 & 1.5 & $\mathrm{u}$ & 0.073 & 0.044 & & 5 & 4 & & 2 \\
\hline Columba livia f. domestica & 30.0 & 1.7 & $\mathrm{u}$ & 0.051 & 0.026 & & 5 & 1 & & 1 \\
\hline Columba oenas & 13.4 & 1.4 & 1 & 0.073 & 0.035 & * & 3 & 3 & 3 & 2 \\
\hline Columba palumbus & 69.4 & 1.7 & 1 & 0.061 & 0.010 & ** & 5 & 5 & 5 & 2 \\
\hline Streptopelia decaocto & 65.8 & 0.7 & 1 & 0.030 & 0.006 & ** & 5 & 1 & 5 & 1 \\
\hline Streptopelia turtur & 72.7 & 1.0 & 0 & -0.003 & 0.007 & & 5 & 3 & 2 & 2 \\
\hline Cuculus canorus & 89.6 & 0.6 & -1 & -0.021 & 0.007 & *** & 5 & 5 & 5 & 3 \\
\hline Apus apus & 9.1 & 0.6 & $\mathrm{u}$ & -0.156 & 0.370 & & 5 & 1 & 5 & 3 \\
\hline Merops apiaster & 27.6 & 1.3 & -1 & -0.056 & 0.028 & $*$ & 2 & 2 & 5 & 3 \\
\hline Upupa epops & 30.3 & 0.8 & $\mathrm{u}$ & -0.023 & 0.015 & & 2 & 5 & 5 & 2 \\
\hline Jynx torquilla & 28.2 & 1.0 & 1 & 0.045 & 0.017 & ** & 5 & 3 & 5 & 3 \\
\hline Picus viridis & 23.6 & 0.9 & 1 & 0.057 & 0.019 & $* *$ & 5 & 3 & 3 & 1 \\
\hline Dryocopos martius & 23.3 & 1.3 & $\mathrm{u}$ & 0.032 & 0.020 & & 3 & 3 & 3 & 1 \\
\hline Dendrocopos major & 57.1 & 1.2 & 1 & 0.016 & 0.007 & $*$ & 3 & 3 & 5 & 1 \\
\hline Dendrocopos syriacus & 8.5 & 0.5 & -1 & -0.081 & 0.038 & $*$ & 5 & 1 & 5 & 1 \\
\hline Dendrocopos medius & 11.5 & 0.6 & 0 & -0.001 & 0.022 & & 3 & 3 & 3 & 1 \\
\hline Dendrocopos minor & 9.5 & 0.8 & $\mathrm{u}$ & -0.021 & 0.030 & & 3 & 3 & 3 & 1 \\
\hline Galerida cristata & 33.6 & 1.3 & -1 & -0.057 & 0.011 & ** & 2 & 2 & 2 & 1 \\
\hline Lullula arborea & 12.6 & 0.8 & -1 & -0.078 & 0.022 & ** & 3 & 3 & 5 & 2 \\
\hline Alauda arvensis & 85.1 & 1.0 & -1 & -0.023 & 0.004 & $* *$ & 2 & 2 & 2 & 2 \\
\hline Riparia riparia & 9.7 & 0.7 & $\mathrm{u}$ & -0.013 & 0.078 & & 2 & 4 & & 3 \\
\hline Hirundo rustica & 79.2 & 1.1 & -1 & -0.070 & 0.011 & *** & 2 & 1 & 2 & 3 \\
\hline Delichon urbica & 42.2 & 1.5 & -1 & -0.071 & 0.018 & ** & 5 & 1 & 5 & 3 \\
\hline Anthus campestris & 8.6 & 1.0 & $\mathrm{u}$ & -0.021 & 0.057 & & 2 & 2 & 5 & 3 \\
\hline Anthus trivialis & 26.6 & 1.4 & 0 & -0.017 & 0.013 & & 5 & 3 & 3 & 3 \\
\hline Anthus pratensis & 5.2 & 0.6 & $\mathrm{u}$ & 0.090 & 0.103 & & 2 & 2 & 2 & 2 \\
\hline Motacilla flava & 45.5 & 1.2 & 0 & 0.008 & 0.007 & & 2 & 2 & 2 & 3 \\
\hline Motacilla alba & 47.1 & 1.4 & 0 & -0.004 & 0.009 & & 2 & 5 & 5 & 2 \\
\hline Troglodytes troglodytes & 15.6 & 1.3 & $\mathrm{u}$ & 0.014 & 0.019 & & 3 & 3 & 3 & 2 \\
\hline Erithacus rubecula & 40.8 & 0.9 & 1 & 0.028 & 0.007 & *** & 3 & 3 & 5 & 2 \\
\hline Luscinia megarhynchos & 75.6 & 0.8 & 0 & 0.005 & 0.005 & & 5 & 3 & 5 & 3 \\
\hline Phoenicurus ochruros & 43.1 & 0.8 & 1 & 0.049 & 0.007 & ** & 5 & 1 & 5 & 2 \\
\hline Saxicola rubetra & 24.7 & 1.2 & -1 & -0.039 & 0.018 & $*$ & 2 & 5 & 2 & 3 \\
\hline Saxicola torquata & 63.8 & 1.1 & -1 & -0.023 & 0.008 & ** & 2 & 4 & 2 & 2 \\
\hline Oenanthe oenanthe & 12.7 & 0.6 & $\mathrm{u}$ & -0.045 & 0.026 & & 2 & 5 & 5 & 3 \\
\hline Turdus merula & 82.9 & 1.2 & 1 & 0.018 & 0.004 & $* *$ & 5 & 1 & 5 & 2 \\
\hline Turdus philomelos & 53.3 & 2.1 & 1 & 0.059 & 0.007 & ** & 3 & 3 & 3 & 2 \\
\hline Turdus viscivorus & 5.5 & 0.6 & $\mathrm{u}$ & 0.057 & 0.042 & & 3 & 3 & 3 & 2 \\
\hline Locustella naevia & 12.3 & 1.0 & -2 & -0.125 & 0.031 & * & 2 & 2 & 5 & 3 \\
\hline Locustella fluviatilis & 23.7 & 2.2 & -1 & -0.072 & 0.018 & ** & 5 & 4 & 5 & 3 \\
\hline Locustella luscinioides & 18.6 & 1.1 & $\mathrm{u}$ & -0.032 & 0.021 & & 4 & 4 & & 3 \\
\hline Acrocephalus schoenobaenus & 27.5 & 1.5 & -1 & -0.037 & 0.015 & $*$ & 2 & 4 & 5 & 3 \\
\hline Acrocephalus palustris & 21.2 & 0.8 & -1 & -0.073 & 0.016 & ** & 2 & 4 & 5 & 3 \\
\hline Acrocephalus scirpaceus & 17.0 & 1.4 & -1 & -0.030 & 0.015 & $*$ & 5 & 4 & 5 & 3 \\
\hline
\end{tabular}




\begin{tabular}{|c|c|c|c|c|c|c|c|c|c|c|}
\hline \multirow[t]{2}{*}{ Species } & \multicolumn{2}{|c|}{ 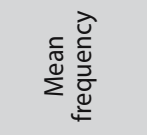 } & \multicolumn{4}{|c|}{ Trend } & \multicolumn{3}{|c|}{ Habitat } & \multirow{2}{*}{$\begin{array}{c}\stackrel{\substack{\circ \\
\frac{0}{0}}}{\stackrel{0}{\circ}} \\
\text { strategy }\end{array}$} \\
\hline & $(\%)$ & (SE) & type & slope & (SE) & & usage & pref. & EBCC & \\
\hline Acrocephalus arundinaceus & 46.1 & 1.4 & 0 & -0.002 & 0.009 & & 2 & 4 & 5 & 3 \\
\hline Hippolais icterina & 5.6 & 0.4 & $\mathrm{u}$ & -0.076 & 0.044 & & 5 & 5 & 5 & 3 \\
\hline Sylvia nisoria & 18.5 & 0.9 & 0 & 0.010 & 0.015 & & 2 & 2 & 2 & 3 \\
\hline Sylvia curruca & 34.0 & 1.4 & 0 & -0.010 & 0.014 & & 5 & 5 & 5 & 3 \\
\hline Sylvia communis & 45.6 & 1.3 & -1 & -0.023 & 0.009 & $* *$ & 2 & 2 & 2 & 3 \\
\hline Sylvia borin & 8.0 & 1.3 & -2 & -0.182 & 0.036 & $* *$ & 5 & 5 & 5 & 3 \\
\hline Sylvia atricapilla & 74.6 & 1.0 & 1 & 0.043 & 0.004 & $* *$ & 5 & 3 & 3 & 2 \\
\hline Phylloscopus sibilatrix & 26.7 & 2.0 & 0 & 0.007 & 0.014 & & 3 & 3 & 3 & 3 \\
\hline Phylloscopus collybita & 59.4 & 1.3 & 1 & 0.010 & 0.005 & * & 3 & 3 & 3 & 2 \\
\hline Phylloscopus trochilus & 17.3 & 1.0 & 0 & -0.009 & 0.016 & & 5 & 3 & 3 & 3 \\
\hline Muscicapa striata & 19.4 & 0.9 & -2 & -0.090 & 0.017 & * & 5 & 3 & 3 & 3 \\
\hline Ficedula albicollis & 16.6 & 1.6 & 2 & 0.092 & 0.018 & $*$ & 3 & 3 & 3 & 3 \\
\hline Aegithalos caudatus & 25.8 & 1.0 & 1 & 0.063 & 0.015 & $* *$ & 5 & 3 & 5 & 1 \\
\hline Parus palustris & 21.0 & 1.0 & 1 & 0.040 & 0.014 & $* *$ & 3 & 3 & 3 & 1 \\
\hline Parus ater & 5.4 & 0.7 & $\mathrm{u}$ & 0.101 & 0.057 & & 3 & 3 & 3 & 1 \\
\hline \begin{tabular}{|l} 
Parus caeruleus \\
\end{tabular} & 36.6 & 1.4 & 1 & 0.045 & 0.009 & $* *$ & 3 & 3 & 5 & 2 \\
\hline Parus major & 78.8 & 1.0 & 1 & 0.032 & 0.005 & $* *$ & 5 & 3 & 5 & 2 \\
\hline Sitta europaea & 28.7 & 1.0 & 1 & 0.026 & 0.011 & * & 3 & 3 & 3 & 1 \\
\hline Certhia brachydactyla & 9.5 & 0.8 & $\mathrm{u}$ & -0.040 & 0.031 & & 3 & 3 & 3 & 1 \\
\hline Oriolus oriolus & 83.6 & 0.9 & 0 & 0.000 & 0.006 & & 5 & 3 & 5 & 3 \\
\hline Lanius collurio & 73.1 & 1.7 & -1 & -0.026 & 0.007 & $* *$ & 2 & 2 & 2 & 3 \\
\hline Lanius minor & 17.7 & 1.3 & -1 & -0.054 & 0.020 & $* *$ & 2 & 2 & 2 & 3 \\
\hline Garrulus glandarius & 49.8 & 1.4 & 0 & 0.012 & 0.009 & & 3 & 3 & 3 & 1 \\
\hline Pica pica & 49.3 & 1.0 & 1 & 0.018 & 0.009 & * & 2 & 1 & 5 & 1 \\
\hline Corvus frugilegus & 21.1 & 0.9 & $\mathrm{u}$ & -0.049 & 0.048 & & 2 & 5 & 2 & 1 \\
\hline Corvus corone cornix & 55.1 & 2.1 & 1 & 0.057 & 0.015 & $* *$ & 2 & 5 & 5 & 1 \\
\hline Corvus corax & 24.1 & 1.5 & 1 & 0.110 & 0.041 & * & 5 & 3 & 5 & 1 \\
\hline Sturnus vulgaris & 91.7 & 0.9 & 0 & 0.016 & 0.010 & & 2 & 2 & 2 & 2 \\
\hline Passer domesticus & 59.7 & 1.7 & -1 & -0.023 & 0.007 & $* *$ & 5 & 1 & 5 & 1 \\
\hline Passer montanus & 78.8 & 0.9 & 1 & 0.013 & 0.007 & * & 2 & 1 & 2 & 1 \\
\hline Fringilla coelebs & 78.7 & 1.4 & 1 & 0.029 & 0.005 & $* *$ & 3 & 3 & 5 & 2 \\
\hline Serinus serinus & 35.3 & 1.5 & -1 & -0.031 & 0.010 & $* *$ & 5 & 1 & 5 & 2 \\
\hline Carduelis chloris & 73.4 & 1.2 & 1 & 0.025 & 0.007 & $* *$ & 5 & 1 & 5 & 2 \\
\hline Carduelis carduelis & 71.5 & 1.1 & 0 & 0.015 & 0.008 & & 2 & 1 & 5 & 2 \\
\hline Carduelis cannabina & 24.8 & 1.2 & 0 & -0.001 & 0.015 & & 2 & 1 & 2 & 2 \\
\hline Coccothraustres coccothraustes & 28.0 & 1.1 & 2 & 0.079 & 0.014 & $*$ & 3 & 3 & 3 & 2 \\
\hline Emberiza citrinella & 59.0 & 1.2 & 0 & -0.001 & 0.005 & & 5 & 3 & 2 & 2 \\
\hline Emberiza schoeniclus & 18.0 & 1.2 & 1 & 0.044 & 0.020 & $*$ & 5 & 4 & 5 & 2 \\
\hline Miliaria calandra & 62.0 & 1.9 & -1 & -0.025 & 0.008 & $* *$ & 2 & 2 & 2 & 1 \\
\hline
\end{tabular}


Table 2. Mean frequency (SE), type of trend with slope (SE) values and source of wintering population of the most common 57 bird species (frequency larger than 5\%) during the wintering season between 2000-2012 in Hungary on the base of MMM data. Mean frequency (SE) estimated from the annual frequencies $(n=13)$. Trend type: $(-2)$ steep decline, $(-1)$ moderate decline, $(0)$ stable, (1) moderate increase, $(+2)$ strong increase, $(\mathrm{u})$ uncertain trend. Source of wintering population: (1) formed fully/partly by Hungarian breeding population, (2) formed fully by foreign breeding populations ( ${ }^{*}: \mathrm{P}<0.05,{ }^{*}$ : $\mathrm{P}<0.01$ )

2. táblázat A leggyakoribb 57 telelő madárfaj átlagos gyakorisága, átlag hibája (SE), a trend típusa és az átlagos éves változás értéke, átlag hibája (SE) és a telelő állomány származása a Magyarországon az MMM keretében, a telelési időszakban 2000 és 2012 között gyűjtött adatok alapján. Az átlagos gyakoriság az évenként számolt gyakorisági értékek alapján számolva ( $n=13)$. Trend típus: $(-2)$ erős csökkenés, $(-1)$ mérsékelt csökkenés, (0) stabil, (1) mérsékelt növekedés, (+2) erős növekedés, (u) bizonytalan trend. A telelő állomány származása: (1) teljesen vagy részben a magyar állomány, (2) főként külföldön fészkelő állomány $\left({ }^{*}: \mathrm{P}<0.05,{ }^{* *}: \mathrm{P}<0.01\right)$

\begin{tabular}{|c|c|c|c|c|c|c|c|}
\hline \multirow[t]{2}{*}{ Species } & \multicolumn{2}{|c|}{ 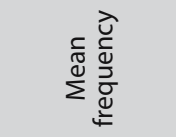 } & \multicolumn{4}{|c|}{ Trend } & \multirow{2}{*}{$\begin{array}{l}\text { Wintering } \\
\text { population }\end{array}$} \\
\hline & (\%) & (SE) & type & slope & (SE) & & \\
\hline Phalacrocorax carbo & 7.2 & 0.5 & $\mathrm{u}$ & 0.072 & 0.052 & & 1 \\
\hline Egretta alba & 10.0 & 0.8 & $\mathrm{u}$ & -0.015 & 0.044 & & 1 \\
\hline Ardea cinerea & 11.8 & 1.0 & 1 & 0.136 & 0.058 & $*$ & 1 \\
\hline Anser fabalis & 7.0 & 1.1 & $\mathrm{u}$ & 0.038 & 0.154 & & 2 \\
\hline Anser albifrons & 8.9 & 1.9 & $\mathrm{u}$ & 0.228 & 0.222 & & 2 \\
\hline Anser anser & 7.0 & 1.9 & $\mathrm{u}$ & 0.159 & 0.377 & & 1 \\
\hline Anas platyrhynchos & 18.9 & 1.7 & 1 & 0.135 & 0.045 & *** & 1 \\
\hline Haliaeetus albicilla & 5.4 & 1.0 & $\mathrm{u}$ & -0.205 & 0.118 & & 1 \\
\hline Circus cyaneus & 22.3 & 2.5 & $\mathrm{u}$ & 0.041 & 0.089 & & 2 \\
\hline Accipiter gentilis & 5.6 & 0.5 & $\mathrm{u}$ & -0.241 & 0.136 & * & 1 \\
\hline Accipiter nisus & 26.2 & 0.9 & $\mathrm{u}$ & -0.032 & 0.045 & & 1 \\
\hline Buteo buteo & 81.3 & 1.0 & 0 & 0.020 & 0.011 & & 1 \\
\hline Buteo lagopus & 9.5 & 1.8 & $\mathrm{u}$ & 0.122 & 0.083 & & 2 \\
\hline Falco tinnunculus & 13.7 & 1.3 & $\mathrm{u}$ & 0.007 & 0.033 & & 1 \\
\hline Phasianus colchicus & 50.3 & 2.0 & -1 & -0.033 & 0.016 & $*$ & 1 \\
\hline Larus ridibundus & 5.9 & 0.4 & $\mathrm{u}$ & 0.160 & 0.160 & & 1 \\
\hline Columba livia f. domestica & 22.3 & 1.6 & 2 & 0.154 & 0.044 & * & 1 \\
\hline Streptopelia decaocto & 40.5 & 1.0 & 1 & 0.080 & 0.023 & $* *$ & 1 \\
\hline Picus viridis & 14.8 & 1.5 & 1 & 0.071 & 0.032 & $*$ & 1 \\
\hline Dryocopos martius & 20.8 & 2.0 & 1 & 0.088 & 0.035 & * & 1 \\
\hline Dendrocopos major & 58.0 & 1.1 & 0 & 0.010 & 0.011 & & 1 \\
\hline Dendrocopos syriacus & 6.8 & 1.1 & $\mathrm{u}$ & 0.098 & 0.075 & & 1 \\
\hline Dendrocopos medius & 10.5 & 0.8 & $\mathrm{u}$ & 0.068 & 0.039 & & 1 \\
\hline Dendrocopos minor & 9.8 & 1.1 & -1 & -0.108 & 0.041 & $* *$ & 1 \\
\hline Galerida cristata & 15.9 & 0.9 & $\mathrm{u}$ & 0.048 & 0.047 & & 1 \\
\hline Troglodytes troglodytes & 25.0 & 2.0 & 0 & -0.005 & 0.019 & & 1 \\
\hline Erithacus rubecula & 15.2 & 1.6 & $\mathrm{u}$ & 0.030 & 0.030 & & 1 \\
\hline Turdus merula & 65.8 & 1.8 & 0 & 0.015 & 0.011 & & 1 \\
\hline Turdus pilaris & 55.1 & 4.2 & $\mathrm{u}$ & 0.004 & 0.026 & & 2 \\
\hline
\end{tabular}




\begin{tabular}{|c|c|c|c|c|c|c|c|}
\hline \multirow[t]{2}{*}{ Species } & \multicolumn{2}{|c|}{ 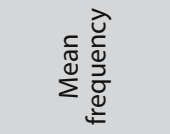 } & \multicolumn{4}{|c|}{ Trend } & \multirow{2}{*}{$\begin{array}{l}\text { Wintering } \\
\text { population }\end{array}$} \\
\hline & $(\%)$ & (SE) & type & slope & (SE) & & \\
\hline Turdus viscivorus & 18.4 & 1.4 & -1 & -0.087 & 0.031 & ** & 1 \\
\hline Regulus regulus & 12.5 & 1.3 & $\mathrm{u}$ & -0.032 & 0.036 & & 2 \\
\hline Aegithalos caudatus & 28.7 & 1.4 & 1 & 0.048 & 0.023 & * & 1 \\
\hline Parus palustris & 29.9 & 1.4 & 1 & 0.059 & 0.021 & $* *$ & 1 \\
\hline Parus ater & 6.9 & 0.9 & $\mathrm{u}$ & 0.056 & 0.082 & & 1 \\
\hline Parus caeruleus & 60.8 & 1.5 & 0 & 0.002 & 0.013 & & 1 \\
\hline Parus major & 88.0 & 1.3 & 1 & 0.038 & 0.008 & $* *$ & 1 \\
\hline Sitta europaea & 33.8 & 1.1 & 1 & 0.028 & 0.013 & * & 1 \\
\hline Certhia familiaris & 7.3 & 0.7 & -1 & -0.015 & 0.069 & * & 1 \\
\hline Certhia brachydactyla & 11.2 & 1.3 & $\mathrm{u}$ & -0.021 & 0.045 & & 1 \\
\hline Lanius excubitor & 24.9 & 1.1 & $\mathrm{u}$ & 0.008 & 0.022 & & 2 \\
\hline Garrulus glandarius & 51.1 & 1.5 & 0 & 0.008 & 0.012 & & 1 \\
\hline Pica pica & 44.2 & 1.9 & $\mathrm{u}$ & 0.026 & 0.014 & & 1 \\
\hline Corvus frugilegus & 42.8 & 1.6 & $\mathrm{u}$ & -0.045 & 0.026 & & 2 \\
\hline Corvus corone cornix & 40.7 & 2.4 & 1 & 0.094 & 0.025 & $* *$ & 1 \\
\hline Corvus corax & 29.5 & 1.6 & 1 & 0.105 & 0.039 & $* *$ & 1 \\
\hline Passer domesticus & 43.4 & 2.3 & $\mathrm{u}$ & -0.021 & 0.017 & & 1 \\
\hline Passer montanus & 60.1 & 1.5 & 0 & -0.007 & 0.015 & & 1 \\
\hline Fringilla coelebs & 39.3 & 1.4 & 2 & 0.136 & 0.027 & ** & 1 \\
\hline Fringilla montifringilla & 16.8 & 2.5 & $\mathrm{u}$ & 0.131 & 0.118 & & 2 \\
\hline Carduelis chloris & 55.3 & 1.4 & 2 & 0.106 & 0.024 & * & 1 \\
\hline Carduelis carduelis & 74.5 & 1.7 & 2 & 0.126 & 0.025 & ** & 1 \\
\hline Carduelis spinus & 13.3 & 1.8 & $\mathrm{u}$ & 0.090 & 0.045 & & 2 \\
\hline Carduelis cannabina & 21.0 & 1.4 & $\mathrm{u}$ & 0.052 & 0.043 & & 1 \\
\hline Pyrrhula pyrrhula & 30.4 & 3.4 & 1 & 0.065 & 0.025 & * & 2 \\
\hline Coccothraustres coccothraustes & 28.7 & 1.8 & 1 & 0.062 & 0.029 & * & 1 \\
\hline Emberiza citrinella & 34.6 & 1.3 & $\mathrm{u}$ & 0.057 & 0.041 & & 1 \\
\hline Emberiza schoeniclus & 19.4 & 2.0 & $\mathrm{u}$ & 0.000 & 0.040 & & 1 \\
\hline
\end{tabular}


Table 3. Number of species in relation to the habitat occupancy (more than $2 / 3$ of the population occurred in the given habitat in Hungary) and habitat preference (the highest relative density found in the given habitat in Hungary). Only species with more than $5 \%$ frequency in Hungary considered

3. táblázat A különböző élőhely használattal (a hazai állomány több, mint 2/3-a az adott élőhely típusban volt felmérve) és élőhely preferenciával (a legnagyobb relatív denzitás az adott élőhely típusban volt) jellemezhető fajok száma. Csak a Magyarországon leggyakoribb fészkelő fajok (átlagos gyakoriság nagyobb, mint 5\%) figyelembe véve (élőhelyek: mezőgazdasági, erdei, vizes, vegyes/egyéb)

\begin{tabular}{|l|r|r|r|r|r|}
\cline { 2 - 6 } \multicolumn{1}{c|}{} & \multicolumn{5}{c|}{ Habitat occupancy } \\
\hline $\begin{array}{c}\text { Habitat } \\
\text { preference }\end{array}$ & Farmland & Forest & Wetlands & Mixed & Total \\
\hline Urban & 6 & 0 & 0 & 10 & 16 \\
\hline Farmland & 20 & 0 & 0 & 0 & 20 \\
\hline Forest & 0 & 21 & 0 & 15 & 36 \\
\hline Wetlands & 11 & 0 & 4 & 7 & 22 \\
\hline Mixed & 7 & 0 & 0 & 5 & 12 \\
\hline Total & $\mathbf{4 4}$ & $\mathbf{2 1}$ & $\mathbf{4}$ & $\mathbf{3 7}$ & $\mathbf{1 0 6}$ \\
\hline
\end{tabular}

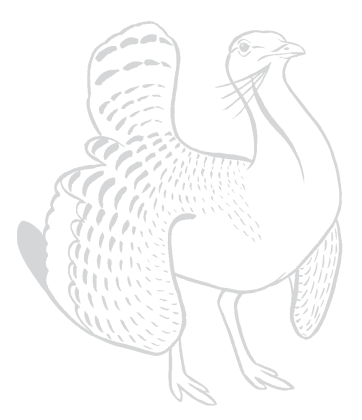




\section{Supplements of article}

\section{Szép T., Nagy K., Nagy Zs., Halmos G. - Population trends of common breeding and wintering birds in Hungary, decline of long-distance migrant and farmland birds during 1999-2012}

Supplement 1. Mean frequency (\%) with standard error (SE) and observed minimum and maximum annual frequency (\%) of the observed 240 bird species during the breeding season between 1999-2012 in Hungary on the base of MMM data. Mean number of annually surveyed $2.5 \times 2.5 \mathrm{~km}$ UTM squares with standard deviation (SD) for each species is given. Only UTM squares were considered where the observers was able identify the species by view/song and field survey has carried out following the standard field protocol. Annual frequency was calculated by dividing the number of UTM squares where the given species was seen/heard on the ground/air at randomly selected points of the square with number of all UTM squares surveyed for the given species. Mean and SE estimated from the annual frequencies $(n=14)$

Melléklet 1. A megfigyelt 240 madárfaj átlagos gyakorisága (\%), átlag hibája (SE), a megfigyelt éves gyakoriság minimum és maximum értékei (\%) a Magyarországon az MMM keretében, a fészkelési időszakban 1999 és 2012 között gyüjtött adatok alapján. Az átlagosan évente felmért 2,5×2,5 km UTM négyzetek száma, az átlag szórása (SD) fajonként megadva. Csak azon UTM négyzetek figyelembe véve, ahol a felmérő látvány és/vagy hang alapján azonosítani tudta az adott fajt és a felmérés az MMM standard protokollja alapján történt. Éves gyakoriság azon UTM négyzetek hányadosa alapján megállapítva, ahol az adott fajt látták/hallották az UTM négyzeten belül lévő random elhelyezkedő megfigyelési pontokon a földön/növényzeten/repülve, osztva azon UTM négyzetekkel, ahol az adott faj jelenlétét/hiányát vizsgálták. Az átlagos gyakoriságot és az átlag hibáját (SE) az évenként számolt gyakorisági értékek alapján számolva ( $n=14)$

\begin{tabular}{|l|c|c|c|c|c|c|}
\hline \multicolumn{1}{|c|}{ Species } & $\begin{array}{c}\text { Mean } \\
\text { frequency } \\
(\%)\end{array}$ & (SE) & $\begin{array}{c}\text { Observed } \\
\text { minimum annual } \\
\text { frequency (\%) }\end{array}$ & $\begin{array}{c}\text { Observed } \\
\text { maximum annual } \\
\text { frequency } \\
\text { (\%) }\end{array}$ & $\begin{array}{c}\text { Mean \# of } \\
\text { annually } \\
\text { surveyed UTM } \\
\text { squares }\end{array}$ & (SD) \\
\hline Tachybaptus ruficollis & 2.5 & 0.5 & 0.0 & 7.8 & 111 & 21.8 \\
\hline Podiceps cristatus & 3.0 & 0.3 & 1.5 & 5.9 & 148 & 30.8 \\
\hline Podiceps grisegena & 0.1 & 0.1 & 0.0 & 1.3 & 85 & 23.4 \\
\hline Podiceps nigricollis & 0.6 & 0.2 & 0.0 & 1.7 & 95 & 21.9 \\
\hline Phalacrocorax carbo & 7.8 & 0.8 & 4.4 & 15.1 & 157 & 28.7 \\
\hline Phalacrocorax pygmeus & 0.9 & 0.5 & 0.0 & 6.3 & 97 & 20.2 \\
\hline Botaurus stellaris & 6.8 & 1.1 & 1.2 & 19.1 & 143 & 25.8 \\
\hline Ixobrychus minutus & 1.6 & 0.2 & 0.0 & 3.0 & 125 & 22.7 \\
\hline Nycticorax nycticorax & 7.6 & 1.0 & 4.7 & 19.0 & 150 & 26.2 \\
\hline Ardeola ralloides & 0.8 & 0.5 & 0.0 & 6.5 & 101 & 21.9 \\
\hline Egretta garzetta & 3.2 & 0.5 & 0.5 & 7.4 & 147 & 26.2 \\
\hline Egretta alba & 19.7 & 2.2 & 11.0 & 42.9 & 153 & 27.4 \\
\hline Ardea cinerea & 35.0 & 1.5 & 28.1 & 47.2 & 158 & 28.4 \\
\hline Ardea purpurea & 5.6 & 0.4 & 3.4 & 7.8 & 141 & 26.5 \\
\hline Bubulcus ibis & 0.1 & 0.1 & 0.0 & 0.9 & 102 & 22.9 \\
\hline Ciconia nigra & 4.7 & 0.8 & 1.8 & 12.9 & 159 & 28.8 \\
\hline Ciconia ciconia & 30.2 & 1.1 & 23.4 & 35.9 & 161 & 29.1 \\
\hline Plegadis falcinellus & 0.0 & 0.0 & 0.0 & 0.7 & 116 & 26.4 \\
\hline Platalea leucorodia & 0.9 & 0.0 & 153 & 29.3 \\
\hline
\end{tabular}




\begin{tabular}{|c|c|c|c|c|c|c|}
\hline Species & $\begin{array}{c}\text { Mean } \\
\text { frequency } \\
(\%)\end{array}$ & (SE) & $\begin{array}{c}\text { Observed } \\
\text { minimum annual } \\
\text { frequency (\%) }\end{array}$ & $\begin{array}{c}\text { Observed } \\
\text { maximum annual } \\
\text { frequency } \\
(\%)\end{array}$ & $\begin{array}{c}\text { Mean \# of } \\
\text { annually } \\
\text { surveyed UTM } \\
\text { squares }\end{array}$ & (SD) \\
\hline Cygnus olor & 3.1 & 0.5 & 0.6 & 7.1 & 152 & 25.4 \\
\hline Cygnus cygnus & 0.0 & 0.0 & 0.0 & 0.7 & 125 & 20.3 \\
\hline Anser fabalis & 0.1 & 0.1 & 0.0 & 0.9 & 126 & 23.7 \\
\hline Anser albifrons & 0.1 & 0.1 & 0.0 & 0.8 & 106 & 17.6 \\
\hline Anser anser & 5.8 & 1.1 & 1.6 & 15.2 & 139 & 25.9 \\
\hline Tadorna tadorna & 0.3 & 0.1 & 0.0 & 1.1 & 98 & 18.3 \\
\hline Anas penelope & 0.3 & 0.2 & 0.0 & 2.6 & 90 & 17.4 \\
\hline Anas strepera & 0.5 & 0.2 & 0.0 & 2.5 & 82 & 18.4 \\
\hline Anas crecca & 0.4 & 0.2 & 0.0 & 2.1 & 111 & 24.8 \\
\hline Anas platyrhynchos & 44.9 & 1.7 & 39.3 & 62.9 & 159 & 28.6 \\
\hline Anas acuta & 0.1 & 0.1 & 0.0 & 1.2 & 98 & 21.9 \\
\hline Anas querquedula & 4.2 & 0.8 & 0.0 & 9.7 & 110 & 24.9 \\
\hline Anas clypeata & 1.1 & 0.3 & 0.0 & 3.4 & 129 & 26.5 \\
\hline Netta rufina & 0.1 & 0.1 & 0.0 & 1.1 & 93 & 17.3 \\
\hline Aythya ferina & 3.2 & 0.7 & 0.0 & 10.4 & 127 & 25.1 \\
\hline Aythya nyroca & 2.3 & 0.6 & 0.0 & 8.8 & 130 & 26.4 \\
\hline Aythya fuligula & 0.3 & 0.1 & 0.0 & 1.4 & 110 & 23.5 \\
\hline Bucephala clangula & 0.1 & 0.1 & 0.0 & 1.1 & 103 & 25.1 \\
\hline Mergus albellus & 0.1 & 0.1 & 0.0 & 0.9 & 81 & 17.6 \\
\hline Mergus merganser & 0.2 & 0.1 & 0.0 & 1.4 & 83 & 16.8 \\
\hline Pernis apivorus & 2.0 & 0.3 & 0.0 & 3.5 & 95 & 21.5 \\
\hline Milvus migrans & 1.5 & 0.3 & 0.0 & 3.5 & 127 & 25.8 \\
\hline Milvus milvus & 0.2 & 0.1 & 0.0 & 1.0 & 116 & 25.2 \\
\hline Haliaeetus albicilla & 2.4 & 0.5 & 0.7 & 7.6 & 134 & 26.2 \\
\hline Circaetus gallicus & 0.2 & 0.2 & 0.0 & 1.9 & 86 & 19.8 \\
\hline Circus aeruginosus & 43.0 & 1.2 & 38.5 & 52.6 & 146 & 25.7 \\
\hline Circus cyaneus & 1.5 & 0.3 & 0.0 & 3.1 & 104 & 19.3 \\
\hline Circus macrourus & 0.3 & 0.2 & 0.0 & 2.0 & 79 & 18.4 \\
\hline Circus pygargus & 5.1 & 0.6 & 0.9 & 8.9 & 106 & 21.5 \\
\hline Accipiter gentilis & 6.4 & 0.4 & 4.7 & 9.6 & 145 & 27.6 \\
\hline Accipiter nisus & 12.6 & 0.9 & 7.6 & 18.9 & 146 & 24.9 \\
\hline Buteo buteo & 80.3 & 1.0 & 74.3 & 87.1 & 158 & 28.9 \\
\hline Buteo rufinus & 0.1 & 0.1 & 0.0 & 1.5 & 64 & 17.4 \\
\hline Buteo lagopus & 0.1 & 0.1 & 0.0 & 0.9 & 117 & 20.0 \\
\hline Aquila pomarina & 0.2 & 0.2 & 0.0 & 2.0 & 64 & 15.1 \\
\hline Aquila heliaca & 2.1 & 0.4 & 0.0 & 4.7 & 110 & 20.7 \\
\hline Hieraaetus pennatus & 0.2 & 0.2 & 0.0 & 2.9 & 49 & 14.1 \\
\hline Pandion haliaetus & 0.2 & 0.1 & 0.0 & 1.3 & 113 & 28.2 \\
\hline Falco tinnunculus & 30.0 & 1.3 & 21.2 & 37.5 & 152 & 26.8 \\
\hline Falco vespertinus & 4.2 & 0.6 & 0.8 & 8.6 & 141 & 26.3 \\
\hline Falco columbarius & 0.2 & 0.1 & 0.0 & 1.1 & 74 & 13.9 \\
\hline Falco subbuteo & 8.0 & 0.6 & 5.4 & 12.4 & 122 & 24.3 \\
\hline Falco cherrug & 1.4 & 0.1 & 0.7 & 2.4 & 122 & 26.9 \\
\hline Falco peregrinus & 0.9 & 0.2 & 0.0 & 2.4 & 118 & 24.3 \\
\hline Perdix perdix & 5.4 & 0.7 & 0.6 & 9.3 & 150 & 27.7 \\
\hline
\end{tabular}




\begin{tabular}{|c|c|c|c|c|c|c|}
\hline Species & $\begin{array}{c}\text { Mean } \\
\text { frequency } \\
(\%)\end{array}$ & (SE) & $\begin{array}{c}\text { Observed } \\
\text { minimum annual } \\
\text { frequency (\%) }\end{array}$ & $\begin{array}{c}\text { Observed } \\
\text { maximum annual } \\
\text { frequency } \\
(\%)\end{array}$ & $\begin{array}{c}\text { Mean \# of } \\
\text { annually } \\
\text { surveyed UTM } \\
\text { squares }\end{array}$ & (SD) \\
\hline Coturnix coturnix & 44.4 & 1.4 & 33.3 & 52.2 & 154 & 28.5 \\
\hline Phasianus colchicus & 90.8 & 0.7 & 85.7 & 94.9 & 161 & 28.6 \\
\hline Rallus aquaticus & 1.7 & 0.6 & 0.0 & 8.9 & 107 & 22.7 \\
\hline Porzana porzana & 0.3 & 0.3 & 0.0 & 4.5 & 64 & 15.1 \\
\hline Porzana parva & 0.7 & 0.4 & 0.0 & 4.5 & 62 & 13.8 \\
\hline Crex crex & 2.6 & 0.6 & 0.0 & 7.2 & 121 & 22.4 \\
\hline Gallinula chloropus & 4.4 & 0.5 & 0.8 & 7.6 & 137 & 24.6 \\
\hline Fulica atra & 10.5 & 0.9 & 5.8 & 17.4 & 155 & 29.2 \\
\hline Grus grus & 1.6 & 0.2 & 0.0 & 3.0 & 153 & 27.9 \\
\hline Otis tarda & 0.6 & 0.1 & 0.0 & 1.5 & 155 & 28.7 \\
\hline Himantopus himantopus & 1.5 & 0.2 & 0.0 & 3.5 & 130 & 27.0 \\
\hline Recurvirostra avosetta & 1.0 & 0.2 & 0.0 & 2.0 & 145 & 31.8 \\
\hline Burhinus oedicnemus & 0.2 & 0.1 & 0.0 & 1.0 & 110 & 25.0 \\
\hline Glareola pratincola & 0.7 & 0.2 & 0.0 & 1.8 & 96 & 19.8 \\
\hline Charadrius dubius & 3.3 & 0.4 & 0.9 & 5.6 & 84 & 20.5 \\
\hline Charadrius hiaticula & 0.2 & 0.1 & 0.0 & 1.4 & 66 & 13.9 \\
\hline Charadrius alexandrinus & 0.1 & 0.1 & 0.0 & 1.2 & 78 & 16.8 \\
\hline Vanellus vanellus & 36.5 & 1.2 & 30.4 & 49.6 & 158 & 29.6 \\
\hline Calidris minuta & 0.3 & 0.2 & 0.0 & 2.2 & 50 & 12.8 \\
\hline Calidris alpina & 0.1 & 0.1 & 0.0 & 2.0 & 45 & 11.1 \\
\hline Philomachus pugnax & 3.0 & 0.4 & 1.3 & 6.3 & 105 & 24.6 \\
\hline Gallinago gallinago & 2.4 & 0.6 & 0.0 & 9.1 & 115 & 19.7 \\
\hline Gallinago media & 0.1 & 0.1 & 0.0 & 1.4 & 69 & 15.4 \\
\hline Scolopax rusticola & 0.1 & 0.1 & 0.0 & 1.1 & 122 & 21.4 \\
\hline Limosa limosa & 3.0 & 0.5 & 0.0 & 6.4 & 105 & 24.0 \\
\hline Numenius phaeopus & 0.9 & 0.2 & 0.0 & 2.1 & 73 & 16.2 \\
\hline Numenius arquata & 1.7 & 0.3 & 0.0 & 4.0 & 102 & 21.9 \\
\hline Tringa erythropus & 1.4 & 0.4 & 0.0 & 3.4 & 62 & 15.5 \\
\hline Tringa totanus & 10.8 & 0.8 & 6.1 & 14.9 & 112 & 24.6 \\
\hline Tringa stagnatilis & 0.2 & 0.2 & 0.0 & 2.2 & 45 & 12.2 \\
\hline Tringa nebularia & 1.1 & 0.4 & 0.0 & 4.7 & 57 & 13.2 \\
\hline Tringa ochropus & 1.3 & 0.3 & 0.0 & 4.3 & 70 & 14.9 \\
\hline Tringa glareola & 5.7 & 1.1 & 0.0 & 15.9 & 66 & 13.3 \\
\hline Actitis hypoleucos & 2.6 & 0.5 & 0.0 & 6.9 & 93 & 17.5 \\
\hline Arenaria interpres & 0.1 & 0.1 & 0.0 & 1.2 & 84 & 19.9 \\
\hline Larus melanocephalus & 0.6 & 0.2 & 0.0 & 2.2 & 82 & 19.6 \\
\hline Larus minutus & 0.3 & 0.2 & 0.0 & 2.6 & 46 & 10.5 \\
\hline Larus ridibundus & 19.2 & 1.5 & 11.2 & 28.9 & 151 & 28.3 \\
\hline Larus canus & 0.3 & 0.2 & 0.0 & 1.8 & 52 & 11.9 \\
\hline Larus fuscus & 0.2 & 0.2 & 0.0 & 2.1 & 41 & 14.3 \\
\hline Larus argentatus & 0.6 & 0.3 & 0.0 & 3.0 & 87 & 20.4 \\
\hline Larus cachinnans & 4.3 & 0.8 & 0.0 & 10.5 & 61 & 13.5 \\
\hline Sterna caspia & 0.1 & 0.1 & 0.0 & 1.4 & 73 & 16.1 \\
\hline Sterna hirundo & 2.3 & 0.3 & 0.8 & 4.1 & 111 & 21.7 \\
\hline Chlidonias hybridus & 3.8 & 1.2 & 0.0 & 17.5 & 83 & 20.0 \\
\hline
\end{tabular}




\begin{tabular}{|c|c|c|c|c|c|c|}
\hline Species & $\begin{array}{c}\text { Mean } \\
\text { frequency } \\
(\%)\end{array}$ & (SE) & $\begin{array}{c}\text { Observed } \\
\text { minimum annual } \\
\text { frequency (\%) }\end{array}$ & $\begin{array}{c}\text { Observed } \\
\text { maximum annual } \\
\text { frequency } \\
(\%)\end{array}$ & $\begin{array}{c}\text { Mean \# of } \\
\text { annually } \\
\text { surveyed UTM } \\
\text { squares }\end{array}$ & (SD) \\
\hline Chlidonias niger & 2.8 & 0.5 & 0.0 & 6.6 & 92 & 21.2 \\
\hline Chlidonias leucopterus & 1.5 & 0.8 & 0.0 & 11.4 & 71 & 18.5 \\
\hline Columba livia f. domestica & 30.0 & 1.7 & 12.3 & 38.1 & 107 & 16.0 \\
\hline Columba oenas & 13.4 & 1.4 & 5.5 & 25.6 & 126 & 26.1 \\
\hline Columba palumbus & 69.4 & 1.7 & 58.8 & 82.1 & 155 & 26.8 \\
\hline Streptopelia decaoto & 65.8 & 0.7 & 62.1 & 71.9 & 161 & 28.9 \\
\hline Streptopelia turtur & 72.7 & 1.0 & 63.7 & 77.1 & 155 & 27.1 \\
\hline Cuculus canorus & 89.6 & 0.6 & 85.6 & 93.7 & 160 & 28.2 \\
\hline Otus scops & 0.2 & 0.1 & 0.0 & 1.3 & 110 & 24.5 \\
\hline Bubo bubo & 0.1 & 0.1 & 0.0 & 0.8 & 144 & 29.3 \\
\hline Athene noctua & 1.4 & 0.4 & 0.0 & 5.4 & 147 & 28.7 \\
\hline Strix aluco & 1.9 & 0.4 & 0.0 & 5.1 & 135 & 26.3 \\
\hline Asio otus & 1.4 & 0.2 & 0.5 & 3.0 & 152 & 28.0 \\
\hline Asio flammeus & 0.3 & 0.2 & 0.0 & 2.3 & 110 & 20.3 \\
\hline Caprimulgus europaeus & 0.6 & 0.2 & 0.0 & 2.5 & 131 & 24.2 \\
\hline Apus apus & 9.1 & 0.6 & 5.7 & 12.8 & 151 & 29.7 \\
\hline Alcedo atthis & 2.8 & 0.5 & 0.6 & 7.4 & 156 & 28.9 \\
\hline Merops apiaster & 27.6 & 1.3 & 18.8 & 35.7 & 159 & 29.4 \\
\hline Coracias garrulus & 3.2 & 0.5 & 0.0 & 8.1 & 147 & 29.2 \\
\hline Upupa epops & 30.3 & 0.8 & 25.4 & 35.9 & 160 & 29.0 \\
\hline Jynx torquilla & 28.2 & 1.0 & 18.7 & 33.7 & 142 & 27.4 \\
\hline Picus canus & 3.7 & 0.7 & 0.8 & 9.1 & 115 & 20.6 \\
\hline Picus viridis & 23.6 & 0.9 & 18.6 & 28.5 & 156 & 26.7 \\
\hline Dryocopos martius & 23.3 & 1.3 & 17.3 & 31.9 & 157 & 27.9 \\
\hline Dendrocopos major & 57.1 & 1.2 & 51.1 & 64.7 & 155 & 25.8 \\
\hline Dendrocopos syriacus & 8.5 & 0.5 & 6.3 & 12.1 & 141 & 24.8 \\
\hline Dendrocopos medius & 11.5 & 0.6 & 7.8 & 15.4 & 138 & 24.6 \\
\hline Dendrocopos leucotos & 0.8 & 0.2 & 0.0 & 2.4 & 112 & 21.1 \\
\hline Dendrocopos minor & 9.5 & 0.8 & 4.4 & 14.6 & 148 & 23.4 \\
\hline Calandrella brachydactyla & 0.5 & 0.3 & 0.0 & 3.0 & 62 & 16.0 \\
\hline Galerida cristata & 33.6 & 1.3 & 24.3 & 39.5 & 158 & 28.5 \\
\hline Lullula arborea & 12.6 & 0.8 & 6.9 & 16.3 & 108 & 18.8 \\
\hline Alauda arvensis & 85.1 & 1.0 & 79.4 & 89.4 & 159 & 28.6 \\
\hline Riparia riparia & 9.7 & 0.7 & 4.2 & 13.4 & 150 & 30.1 \\
\hline Hirundo rustica & 79.2 & 1.1 & 68.3 & 83.8 & 160 & 29.2 \\
\hline Delichon urbica & 42.2 & 1.5 & 32.0 & 49.3 & 159 & 28.2 \\
\hline Anthus campestris & 8.6 & 1.0 & 4.1 & 15.8 & 75 & 16.1 \\
\hline Anthus trivialis & 26.6 & 1.4 & 17.1 & 34.2 & 105 & 18.6 \\
\hline Anthus pratensis & 5.2 & 0.6 & 2.3 & 10.9 & 70 & 12.7 \\
\hline Anthus cervinus & 1.3 & 0.6 & 0.0 & 7.3 & 48 & 12.6 \\
\hline Anthus spinoletta & 0.2 & 0.2 & 0.0 & 2.9 & 41 & 10.7 \\
\hline Motacilla flava & 45.5 & 1.2 & 37.7 & 50.3 & 149 & 26.9 \\
\hline Motacilla citreola & 0.1 & 0.1 & 0.0 & 1.0 & 70 & 11.6 \\
\hline Motacilla cinerea & 1.6 & 0.3 & 0.0 & 4.5 & 115 & 22.1 \\
\hline Motacilla alba & 47.1 & 1.4 & 40.4 & 57.5 & 160 & 29.3 \\
\hline
\end{tabular}




\begin{tabular}{|c|c|c|c|c|c|c|}
\hline Species & $\begin{array}{c}\text { Mean } \\
\text { frequency } \\
(\%)\end{array}$ & (SE) & $\begin{array}{c}\text { Observed } \\
\text { minimum annual } \\
\text { frequency (\%) }\end{array}$ & $\begin{array}{c}\text { Observed } \\
\text { maximum annual } \\
\text { frequency } \\
(\%)\end{array}$ & $\begin{array}{c}\text { Mean \# of } \\
\text { annually } \\
\text { surveyed UTM } \\
\text { squares }\end{array}$ & $(\mathrm{SD})$ \\
\hline Bombycilla garrulus & 0.2 & 0.1 & 0.0 & 1.7 & 149 & 24.6 \\
\hline Cinclus cinclus & 0.1 & 0.1 & 0.0 & 1.3 & 131 & 27.8 \\
\hline Troglodytes troglodytes & 15.6 & 1.3 & 8.9 & 23.9 & 156 & 25.6 \\
\hline Prunella modularis & 2.7 & 0.4 & 0.0 & 6.0 & 107 & 23.9 \\
\hline Erithacus rubecula & 40.8 & 0.9 & 36.3 & 45.8 & 159 & 27.7 \\
\hline Luscinia luscinia & 0.8 & 0.3 & 0.0 & 3.2 & 102 & 23.5 \\
\hline Luscinia megarhynchos & 75.6 & 0.8 & 68.5 & 81.2 & 157 & 28.1 \\
\hline Luscinia svecica & 1.5 & 0.5 & 0.0 & 5.5 & 141 & 26.8 \\
\hline Phoenicurus ochruros & 43.1 & 0.8 & 35.9 & 48.7 & 159 & 27.8 \\
\hline Phoenicurus phoenicurus & 2.6 & 0.4 & 0.0 & 5.6 & 151 & 27.5 \\
\hline Saxicola rubetra & 24.7 & 1.2 & 15.0 & 29.6 & 131 & 26.6 \\
\hline Saxicola torquata & 63.8 & 1.1 & 56.2 & 70.6 & 151 & 27.5 \\
\hline Oenanthe oenanthe & 12.7 & 0.6 & 9.2 & 16.4 & 121 & 23.5 \\
\hline Turdus merula & 82.9 & 1.2 & 75.5 & 89.4 & 161 & 28.9 \\
\hline Turdus pilaris & 1.4 & 0.2 & 0.6 & 3.0 & 148 & 22.2 \\
\hline Turdus philomelos & 53.3 & 2.1 & 41.8 & 64.0 & 151 & 24.9 \\
\hline Turdus iliacus & 0.1 & 0.1 & 0.0 & 1.0 & 118 & 25.2 \\
\hline Turdus viscivorus & 5.5 & 0.6 & 1.8 & 9.5 & 121 & 23.2 \\
\hline Locustella naevia & 12.3 & 1.0 & 6.5 & 20.0 & 102 & 17.5 \\
\hline Locustella fluviatilis & 23.7 & 2.2 & 8.9 & 38.9 & 115 & 18.7 \\
\hline Locustella luscinioides & 18.6 & 1.1 & 12.9 & 30.0 & 117 & 22.1 \\
\hline Acrocephalus melanopogon & 1.1 & 0.4 & 0.0 & 4.4 & 84 & 15.3 \\
\hline Acrocephalus paludicola & 0.3 & 0.2 & 0.0 & 3.0 & 93 & 17.3 \\
\hline Acrocephalus schoenobaenus & 27.5 & 1.5 & 18.7 & 40.6 & 99 & 20.7 \\
\hline Acrocephalus palustris & 21.2 & 0.8 & 14.0 & 26.4 & 103 & 19.3 \\
\hline Acrocephalus scirpaceus & 17.0 & 1.4 & 8.0 & 25.8 & 116 & 19.6 \\
\hline Acrocephalus arundinaceus & 46.1 & 1.4 & 34.7 & 55.7 & 147 & 28.6 \\
\hline Hippolais pallida & 0.2 & 0.2 & 0.0 & 1.6 & 51 & 11.7 \\
\hline Hippolais icterina & 5.6 & 0.4 & 2.4 & 8.6 & 89 & 13.8 \\
\hline Sylvia nisoria & 18.5 & 0.9 & 15.0 & 26.2 & 117 & 26.5 \\
\hline Sylvia curruca & 34.0 & 1.4 & 27.8 & 43.0 & 101 & 21.8 \\
\hline Sylvia communis & 45.6 & 1.3 & 35.1 & 52.9 & 123 & 24.9 \\
\hline Sylvia borin & 8.0 & 1.3 & 3.0 & 16.0 & 105 & 18.4 \\
\hline Sylvia atricapilla & 74.6 & 1.0 & 67.8 & 79.6 & 151 & 26.6 \\
\hline Phylloscopus sibilatrix & 26.7 & 2.0 & 11.9 & 41.7 & 107 & 18.8 \\
\hline Phylloscopus collybita & 59.4 & 1.3 & 50.9 & 69.4 & 147 & 25.4 \\
\hline Phylloscopus trochilus & 17.3 & 1.0 & 11.8 & 23.0 & 110 & 19.2 \\
\hline Regulus regulus & 2.1 & 0.3 & 0.7 & 5.2 & 139 & 25.8 \\
\hline Regulus ignicapellus & 0.5 & 0.2 & 0.0 & 2.1 & 137 & 27.1 \\
\hline Muscicapa striata & 19.4 & 0.9 & 15.7 & 25.2 & 122 & 26.3 \\
\hline Ficedula parva & 0.9 & 0.2 & 0.0 & 2.2 & 103 & 20.5 \\
\hline Ficedula albicollis & 16.6 & 1.6 & 7.2 & 27.5 & 129 & 25.0 \\
\hline Ficedula hypoleuca & 2.6 & 0.4 & 0.0 & 5.4 & 127 & 24.0 \\
\hline Panurus biarmicus & 1.8 & 0.4 & 0.0 & 4.9 & 138 & 26.7 \\
\hline Aegithalos caudatus & 25.8 & 1.0 & 21.5 & 31.9 & 158 & 27.1 \\
\hline
\end{tabular}




\begin{tabular}{|c|c|c|c|c|c|c|}
\hline Species & $\begin{array}{c}\text { Mean } \\
\text { frequency } \\
(\%)\end{array}$ & (SE) & $\begin{array}{c}\text { Observed } \\
\text { minimum annual } \\
\text { frequency (\%) }\end{array}$ & $\begin{array}{c}\text { Observed } \\
\text { maximum annual } \\
\text { frequency } \\
(\%)\end{array}$ & $\begin{array}{c}\text { Mean \# of } \\
\text { annually } \\
\text { surveyed UTM } \\
\text { squares }\end{array}$ & (SD) \\
\hline Parus palustris & 21.0 & 1.0 & 15.9 & 27.5 & 150 & 25.4 \\
\hline Parus montanus & 1.3 & 0.3 & 0.0 & 4.1 & 104 & 18.2 \\
\hline Parus cristatus & 0.8 & 0.2 & 0.0 & 2.1 & 143 & 26.2 \\
\hline Parus ater & 5.4 & 0.7 & 1.9 & 10.6 & 132 & 21.3 \\
\hline Parus caeruleus & 36.6 & 1.4 & 25.3 & 43.0 & 160 & 28.4 \\
\hline Parus major & 78.8 & 1.0 & 73.6 & 86.7 & 161 & 28.9 \\
\hline Sitta europaea & 28.7 & 1.0 & 21.0 & 35.5 & 156 & 27.6 \\
\hline Certhia familiaris & 4.0 & 0.7 & 0.0 & 8.8 & 81 & 13.8 \\
\hline Certhia brachydactyla & 9.5 & 0.8 & 4.2 & 13.7 & 97 & 16.2 \\
\hline Remiz pendulinus & 3.7 & 0.4 & 0.9 & 6.1 & 141 & 28.2 \\
\hline Oriolus oriolus & 83.6 & 0.9 & 77.1 & 88.5 & 159 & 28.8 \\
\hline Lanius collurio & 73.1 & 1.7 & 55.9 & 79.1 & 157 & 28.4 \\
\hline Lanius minor & 17.7 & 1.3 & 10.3 & 24.2 & 130 & 28.5 \\
\hline Lanius exubitor & 1.4 & 0.4 & 0.0 & 4.8 & 140 & 26.6 \\
\hline Garrulus glandarius & 49.8 & 1.4 & 42.3 & 56.8 & 159 & 28.6 \\
\hline Pica pica & 49.3 & 1.0 & 42.8 & 55.8 & 161 & 29.2 \\
\hline Corvus monedula & 4.3 & 0.5 & 1.6 & 7.8 & 158 & 28.0 \\
\hline Corvus frugilegus & 21.1 & 0.9 & 15.8 & 28.6 & 161 & 28.6 \\
\hline Corvus corone cornix & 55.1 & 2.1 & 39.0 & 65.7 & 159 & 28.5 \\
\hline Corvus corax & 24.1 & 1.5 & 14.2 & 35.9 & 159 & 27.6 \\
\hline Sturnus vulgaris & 91.7 & 0.9 & 86.5 & 96.5 & 161 & 28.5 \\
\hline Sturnus roseus & 0.1 & 0.1 & 0.0 & 1.0 & 101 & 25.6 \\
\hline Passer domesticus & 59.7 & 1.7 & 44.0 & 68.1 & 161 & 29.3 \\
\hline Passer montanus & 78.8 & 0.9 & 73.3 & 83.5 & 160 & 28.3 \\
\hline Fringilla coelebs & 78.7 & 1.4 & 72.1 & 87.1 & 157 & 28.1 \\
\hline Fringilla montifringilla & 0.5 & 0.2 & 0.0 & 1.4 & 134 & 22.1 \\
\hline Serinus serinus & 35.3 & 1.5 & 26.5 & 44.1 & 144 & 25.3 \\
\hline Carduelis chloris & 73.4 & 1.2 & 66.5 & 82.1 & 158 & 28.5 \\
\hline Carduelis carduelis & 71.5 & 1.1 & 66.9 & 80.2 & 159 & 28.2 \\
\hline Carduelis spinus & 2.2 & 0.5 & 0.7 & 5.2 & 138 & 25.7 \\
\hline Carduelis cannabina & 24.8 & 1.2 & 19.9 & 32.6 & 138 & 22.6 \\
\hline Carduelis flammea & 0.2 & 0.1 & 0.0 & 1.7 & 103 & 21.0 \\
\hline Loxia curvirostra & 0.6 & 0.2 & 0.0 & 1.9 & 145 & 26.9 \\
\hline Pyrrhula pyrrhula & 0.8 & 0.1 & 0.0 & 2.2 & 150 & 25.6 \\
\hline Coccothraustres coccothraustes & 28.0 & 1.1 & 21.3 & 35.1 & 158 & 27.0 \\
\hline Emberiza citrinella & 59.0 & 1.2 & 52.2 & 65.9 & 151 & 27.8 \\
\hline Emberiza cirlus & 0.1 & 0.1 & 0.0 & 1.1 & 71 & 15.9 \\
\hline Emberiza cia & 1.5 & 0.3 & 0.0 & 2.9 & 97 & 18.1 \\
\hline Emberiza hortulana & 0.4 & 0.2 & 0.0 & 2.1 & 77 & 15.8 \\
\hline Emberiza schoeniclus & 18.0 & 1.2 & 11.8 & 28.8 & 117 & 21.3 \\
\hline Miliaria calandra & 62.0 & 1.9 & 51.4 & 76.2 & 141 & 23.3 \\
\hline
\end{tabular}


Supplement 2. Mean frequency (\%) with standard error (SE) and observed minimum and maximum annual frequency (\%) of the surveyed 140 bird species during the wintering season between 2000-2012 in Hungary on the base of MMM data. Mean number of annually surveyed $2.5 \times 2.5 \mathrm{~km}$ UTM squares with standard deviation (SD) for each species is given. Only UTM squares were considered where the observers was able identify the species by view/song and field survey has carried out following the standard field protocol. Annual frequency was calculated by dividing the number of UTM squares where the given species was seen/heard on the ground/air at randomly selected points of the square with number of all UTM squares surveyed for the given species. Mean and SE estimated from the annual frequencies $(n=13)$

Melléklet 2. A megfigyelt 140 madárfaj átlagos gyakorisága (\%), átlag hibája (SE), a megfigyelt éves gyakoriság minimum és maximum értékei (\%) a Magyarországon az MMM keretében, a telelési időszakban 2000 és 2012 között gyüjtött adatok alapján. Az átlagosan évente felmért 2,5×2,5 km UTM négyzetek száma, az átlag szórása (SD) fajonként megadva. Csak azon UTM négyzetek figyelembe véve, ahol a felmérő látvány és/vagy hang alapján azonosítani tudta az adott fajt és a felmérés az MMM standard protokollja alapján történt. Éves gyakoriság azon UTM négyzetek hányadosa alapján megállapítva, ahol az adott fajt látták/hallották az UTM négyzeten belül lévő random elhelyezkedő megfigyelési pontokon a földön/növényzeten/repülve, osztva azon UTM négyzetekkel, ahol az adott faj jelenlétét/hiányát vizsgálták. Az átlagos gyakoriságot és az átlag hibáját (SE) az évenként számolt gyakorisági értékek alapján számolva $(n=13)$

\begin{tabular}{|l|c|c|c|c|c|c|}
\hline \multicolumn{1}{|c|}{ Species } & $\begin{array}{c}\text { Mean } \\
\text { frequency } \\
(\%)\end{array}$ & (SE) & $\begin{array}{c}\text { Observed } \\
\text { minimum annual } \\
\text { frequency (\%) }\end{array}$ & $\begin{array}{c}\text { Observed } \\
\text { maximum annual } \\
\text { frequency } \\
(\%)\end{array}$ & $\begin{array}{c}\text { Mean \# of } \\
\text { annually } \\
\text { surveyed UTM } \\
\text { squares }\end{array}$ & (SD) \\
\hline Tachybaptus ruficollis & 2.1 & 0.4 & 0.0 & 4.1 & 70 & 15.5 \\
\hline Phalacrocorax carbo & 7.2 & 0.5 & 4.3 & 10.0 & 99 & 22.6 \\
\hline Botaurus stellaris & 0.4 & 0.2 & 0.0 & 2.3 & 89 & 20.7 \\
\hline Egretta alba & 10.0 & 0.8 & 6.1 & 14.4 & 97 & 21.9 \\
\hline Ardea cinerea & 11.8 & 1.0 & 7.8 & 19.0 & 99 & 22.3 \\
\hline Cygnus olor & 2.7 & 0.6 & 0.8 & 8.0 & 97 & 22.9 \\
\hline Cygnus cygnus & 0.2 & 0.2 & 0.0 & 2.5 & 82 & 19.2 \\
\hline Anser fabalis & 7.0 & 1.1 & 2.2 & 13.0 & 78 & 17.7 \\
\hline Anser albifrons & 8.9 & 1.9 & 2.5 & 25.6 & 70 & 16.3 \\
\hline Anser anser & 7.0 & 1.9 & 0.0 & 21.2 & 88 & 19.5 \\
\hline Branta ruficollis & 0.3 & 0.3 & 0.0 & 3.3 & 57 & 12.8 \\
\hline Anas penelope & 0.2 & 0.1 & 0.0 & 1.4 & 58 & 13.7 \\
\hline Anas crecca & 2.1 & 0.5 & 0.0 & 6.2 & 68 & 14.5 \\
\hline Anas platyrhynchos & 18.9 & 1.7 & 12.1 & 30.2 & 101 & 22.4 \\
\hline Anas acuta & 0.2 & 0.2 & 0.0 & 2.7 & 61 & 11.5 \\
\hline Aythya ferina & 1.4 & 0.3 & 0.0 & 2.6 & 80 & 16.7 \\
\hline Aythya nyroca & 0.2 & 0.1 & 0.0 & 1.3 & 79 & 17.1 \\
\hline Aythya fuligula & 0.9 & 0.3 & 0.0 & 2.6 & 68 & 13.9 \\
\hline Somaterina mollissima & 0.2 & 0.2 & 0.0 & 3.0 & 48 & 10.0 \\
\hline Bucephala clangula & 3.2 & 0.5 & 0.0 & 6.8 & 63 & 12.7 \\
\hline Mergus albellus & 0.5 & 0.4 & 0.0 & 4.7 & 49 & 12.3 \\
\hline Mergus merganser & 0.6 & 0.2 & 0.0 & 2.1 & 52 & 11.2 \\
\hline Milvus milvus & 0.1 & 0.1 & 0.0 & 1.2 & 74 & 16.0 \\
\hline Haliaeetus albicilla & 5.4 & 1.0 & 1.3 & 12.9 & 84 & 19.3 \\
\hline
\end{tabular}




\begin{tabular}{|c|c|c|c|c|c|c|}
\hline Species & $\begin{array}{c}\text { Mean } \\
\text { frequency } \\
(\%)\end{array}$ & (SE) & $\begin{array}{c}\text { Observed } \\
\text { minimum annual } \\
\text { frequency (\%) }\end{array}$ & $\begin{array}{c}\text { Observed } \\
\text { maximum annual } \\
\text { frequency } \\
(\%)\end{array}$ & $\begin{array}{c}\text { Mean \# of } \\
\text { annually } \\
\text { surveyed UTM } \\
\text { squares }\end{array}$ & (SD) \\
\hline Circus aeruginosus & 2.0 & 0.5 & 0.0 & 5.1 & 92 & 20.0 \\
\hline Circus cyaneus & 22.3 & 2.5 & 9.5 & 40.8 & 67 & 15.6 \\
\hline Accipiter gentilis & 5.6 & 0.5 & 2.8 & 9.9 & 92 & 21.0 \\
\hline Accipiter nisus & 26.2 & 0.9 & 21.0 & 30.9 & 93 & 21.9 \\
\hline Buteo buteo & 81.3 & 1.0 & 74.8 & 87.2 & 101 & 22.2 \\
\hline Buteo rufinus & 0.1 & 0.1 & 0.0 & 1.8 & 40 & 8.5 \\
\hline Buteo lagopus & 9.5 & 1.8 & 2.4 & 20.2 & 76 & 17.8 \\
\hline Aquila clanga & 0.3 & 0.3 & 0.0 & 4.2 & 35 & 7.7 \\
\hline Aquila heliaca & 2.3 & 0.6 & 0.0 & 6.3 & 70 & 15.8 \\
\hline Aquila chrysaetos & 0.2 & 0.2 & 0.0 & 1.7 & 58 & 11.2 \\
\hline Falco tinnunculus & 13.7 & 1.3 & 6.5 & 21.9 & 97 & 21.6 \\
\hline Falco columbarius & 3.2 & 0.6 & 0.0 & 7.4 & 48 & 12.1 \\
\hline Falco cherrug & 0.8 & 0.4 & 0.0 & 5.0 & 74 & 16.5 \\
\hline Falco peregrinus & 1.4 & 0.3 & 0.0 & 3.5 & 73 & 17.2 \\
\hline Perdix perdix & 1.6 & 0.3 & 0.0 & 3.7 & 96 & 21.3 \\
\hline Coturnix coturnix & 0.1 & 0.1 & 0.0 & 1.0 & 97 & 21.5 \\
\hline Phasianus colchicus & 50.3 & 2.0 & 44.1 & 64.1 & 101 & 22.8 \\
\hline Rallus aquaticus & 0.1 & 0.1 & 0.0 & 1.2 & 66 & 14.3 \\
\hline Gallinula chloropus & 0.2 & 0.2 & 0.0 & 2.3 & 88 & 19.9 \\
\hline Fulica atra & 1.5 & 0.2 & 0.0 & 2.8 & 97 & 20.9 \\
\hline Grus grus & 0.7 & 0.3 & 0.0 & 4.0 & 97 & 22.5 \\
\hline Otis tarda & 0.3 & 0.2 & 0.0 & 1.9 & 97 & 21.2 \\
\hline Vanellus vanellus & 0.1 & 0.1 & 0.0 & 0.9 & 99 & 21.9 \\
\hline Gallinago gallinago & 0.1 & 0.1 & 0.0 & 1.1 & 72 & 16.5 \\
\hline Scolopax rusticola & 0.1 & 0.1 & 0.0 & 1.2 & 79 & 17.4 \\
\hline Tringa ochropus & 0.3 & 0.2 & 0.0 & 2.6 & 41 & 10.2 \\
\hline Larus ridibundus & 5.9 & 0.4 & 3.6 & 8.1 & 94 & 20.7 \\
\hline Larus canus & 3.4 & 1.0 & 0.0 & 11.4 & 32 & 9.0 \\
\hline Larus fuscus & 0.4 & 0.4 & 0.0 & 5.6 & 24 & 5.6 \\
\hline Larus argentatus & 0.6 & 0.4 & 0.0 & 4.3 & 53 & 10.5 \\
\hline Larus cachinnans & 3.2 & 1.1 & 0.0 & 12.5 & 39 & 9.9 \\
\hline Columba livia f. domestica & 22.3 & 1.6 & 7.1 & 30.5 & 70 & 18.6 \\
\hline Columba oenas & 4.7 & 0.8 & 1.4 & 10.5 & 78 & 19.6 \\
\hline Columba palumbus & 0.9 & 0.2 & 0.0 & 3.0 & 98 & 22.0 \\
\hline Streptopelia decaoto & 40.5 & 1.0 & 34.4 & 44.3 & 101 & 22.4 \\
\hline Streptopelia turtur & 0.2 & 0.2 & 0.0 & 3.2 & 98 & 22.3 \\
\hline Tyto alba & 0.1 & 0.1 & 0.0 & 1.1 & 94 & 20.7 \\
\hline Athene noctua & 0.4 & 0.2 & 0.0 & 1.5 & 92 & 19.9 \\
\hline Strix aluco & 0.7 & 0.2 & 0.0 & 2.3 & 84 & 18.1 \\
\hline Strix uralensis & 0.3 & 0.2 & 0.0 & 2.0 & 56 & 11.1 \\
\hline Asio otus & 1.6 & 0.3 & 0.0 & 3.3 & 96 & 22.0 \\
\hline Asio flammeus & 0.8 & 0.5 & 0.0 & 5.8 & 69 & 15.8 \\
\hline Alcedo atthis & 1.1 & 0.2 & 0.0 & 2.2 & 98 & 21.3 \\
\hline Picus canus & 2.9 & 0.8 & 0.0 & 9.2 & 73 & 16.9 \\
\hline Picus viridis & 14.8 & 1.5 & 5.9 & 26.2 & 98 & 22.1 \\
\hline
\end{tabular}




\begin{tabular}{|c|c|c|c|c|c|c|}
\hline Species & $\begin{array}{c}\text { Mean } \\
\text { frequency } \\
(\%)\end{array}$ & (SE) & $\begin{array}{c}\text { Observed } \\
\text { minimum annual } \\
\text { frequency (\%) }\end{array}$ & $\begin{array}{c}\text { Observed } \\
\text { maximum annual } \\
\text { frequency } \\
(\%)\end{array}$ & $\begin{array}{c}\text { Mean \# of } \\
\text { annually } \\
\text { surveyed UTM } \\
\text { squares }\end{array}$ & $(\mathrm{SD})$ \\
\hline Dryocopos martius & 20.8 & 2.0 & 11.8 & 32.1 & 99 & 22.5 \\
\hline Dendrocopos major & 58.0 & 1.1 & 51.8 & 66.7 & 98 & 23.3 \\
\hline Dendrocopos syriacus & 6.8 & 1.1 & 1.8 & 13.5 & 89 & 21.1 \\
\hline Dendrocopos medius & 10.5 & 0.8 & 5.4 & 14.6 & 86 & 19.6 \\
\hline Dendrocopos leucotos & 0.4 & 0.2 & 0.0 & 1.2 & 70 & 16.7 \\
\hline Dendrocopos minor & 9.8 & 1.1 & 3.5 & 15.2 & 94 & 22.2 \\
\hline Galerida cristata & 15.9 & 0.9 & 11.4 & 20.5 & 100 & 22.8 \\
\hline Lullula arborea & 0.1 & 0.1 & 0.0 & 1.1 & 69 & 15.8 \\
\hline Alauda arvensis & 2.4 & 0.6 & 0.0 & 8.2 & 100 & 22.4 \\
\hline Eremophila alpestris & 0.4 & 0.4 & 0.0 & 4.8 & 30 & 7.5 \\
\hline Anthus pratensis & 2.0 & 0.7 & 0.0 & 8.3 & 46 & 9.9 \\
\hline Anthus spinoletta & 1.9 & 1.4 & 0.0 & 18.4 & 26 & 6.0 \\
\hline Motacilla cinerea & 0.1 & 0.1 & 0.0 & 1.3 & 72 & 14.8 \\
\hline Motacilla alba & 0.6 & 0.2 & 0.0 & 2.0 & 101 & 21.9 \\
\hline Bombycilla garrulus & 1.8 & 0.8 & 0.0 & 7.7 & 94 & 21.6 \\
\hline Troglodytes troglodytes & 25.0 & 2.0 & 14.4 & 38.0 & 99 & 22.7 \\
\hline Prunella modularis & 1.0 & 0.3 & 0.0 & 2.9 & 67 & 15.4 \\
\hline Erithacus rubecula & 15.2 & 1.6 & 2.2 & 25.5 & 99 & 22.4 \\
\hline Phoenicurus ochruros & 0.7 & 0.3 & 0.0 & 2.9 & 101 & 22.4 \\
\hline Saxicola torquata & 0.1 & 0.1 & 0.0 & 1.0 & 93 & 19.9 \\
\hline Turdus merula & 65.8 & 1.8 & 54.2 & 76.3 & 101 & 22.7 \\
\hline Turdus pilaris & 55.1 & 4.2 & 25.7 & 73.8 & 95 & 22.7 \\
\hline Turdus philomelos & 3.5 & 0.8 & 0.9 & 10.0 & 95 & 20.7 \\
\hline Turdus iliacus & 3.5 & 0.9 & 0.0 & 10.9 & 75 & 16.1 \\
\hline Turdus viscivorus & 18.4 & 1.4 & 10.3 & 27.8 & 74 & 15.0 \\
\hline Sylvia atricapilla & 0.2 & 0.1 & 0.0 & 1.1 & 94 & 19.6 \\
\hline Phylloscopus collybita & 0.1 & 0.1 & 0.0 & 1.0 & 92 & 20.0 \\
\hline Regulus regulus & 12.5 & 1.3 & 4.3 & 20.6 & 88 & 19.3 \\
\hline Regulus ignicapellus & 0.6 & 0.3 & 0.0 & 2.5 & 87 & 17.8 \\
\hline Panurus biarmicus & 1.1 & 0.4 & 0.0 & 5.1 & 87 & 18.9 \\
\hline Aegithalos caudatus & 28.7 & 1.4 & 18.4 & 34.9 & 101 & 22.8 \\
\hline Parus palustris & 29.9 & 1.4 & 19.4 & 39.6 & 95 & 22.2 \\
\hline Parus montanus & 2.0 & 0.5 & 0.0 & 5.0 & 68 & 16.9 \\
\hline Parus cristatus & 0.9 & 0.2 & 0.0 & 2.1 & 90 & 19.8 \\
\hline Parus ater & 6.9 & 0.9 & 2.4 & 12.2 & 83 & 19.4 \\
\hline Parus caeruleus & 60.8 & 1.5 & 47.6 & 70.6 & 101 & 22.7 \\
\hline Parus major & 88.0 & 1.3 & 80.9 & 95.8 & 101 & 22.6 \\
\hline Sitta europaea & 33.8 & 1.1 & 26.0 & 42.7 & 99 & 22.9 \\
\hline Certhia familiaris & 7.3 & 0.7 & 3.4 & 12.5 & 51 & 12.5 \\
\hline Certhia brachydactyla & 11.2 & 1.3 & 4.2 & 19.4 & 64 & 18.3 \\
\hline Remiz pendulinus & 0.8 & 0.4 & 0.0 & 5.0 & 88 & 18.4 \\
\hline Lanius exubitor & 24.9 & 1.1 & 19.2 & 32.2 & 89 & 19.6 \\
\hline Garrulus glandarius & 51.1 & 1.5 & 41.4 & 58.5 & 101 & 22.2 \\
\hline Pica pica & 44.2 & 1.9 & 32.3 & 54.0 & 101 & 22.9 \\
\hline Nucifraga caryocatactes & 0.1 & 0.1 & 0.0 & 1.6 & 69 & 14.4 \\
\hline
\end{tabular}




\begin{tabular}{|c|c|c|c|c|c|c|}
\hline Species & $\begin{array}{c}\text { Mean } \\
\text { frequency } \\
(\%)\end{array}$ & (SE) & $\begin{array}{c}\text { Observed } \\
\text { minimum annual } \\
\text { frequency }(\%)\end{array}$ & $\begin{array}{c}\text { Observed } \\
\text { maximum annual } \\
\text { frequency } \\
(\%)\end{array}$ & $\begin{array}{c}\text { Mean \# of } \\
\text { annually } \\
\text { surveyed UTM } \\
\text { squares }\end{array}$ & (SD) \\
\hline Corvus monedula & 4.2 & 0.6 & 1.7 & 8.9 & 99 & 23.1 \\
\hline Corvus frugilegus & 42.8 & 1.6 & 36.1 & 56.0 & 101 & 22.9 \\
\hline Corvus corone cornix & 40.7 & 2.4 & 28.3 & 52.2 & 100 & 22.8 \\
\hline Corvus corax & 29.5 & 1.6 & 20.2 & 37.2 & 100 & 23.0 \\
\hline Sturnus vulgaris & 3.4 & 0.8 & 0.0 & 9.8 & 101 & 22.7 \\
\hline Passer domesticus & 43.4 & 2.3 & 33.0 & 59.0 & 102 & 22.6 \\
\hline Passer montanus & 60.1 & 1.5 & 50.5 & 68.6 & 101 & 22.7 \\
\hline Fringilla coelebs & 39.3 & 1.4 & 29.8 & 47.3 & 98 & 21.4 \\
\hline Fringilla montifringilla & 16.8 & 2.5 & 3.9 & 39.2 & 85 & 17.8 \\
\hline Serinus serinus & 0.8 & 0.3 & 0.0 & 3.0 & 91 & 19.3 \\
\hline Carduelis chloris & 55.3 & 1.4 & 48.4 & 65.9 & 99 & 22.9 \\
\hline Carduelis carduelis & 74.5 & 1.7 & 66.4 & 84.3 & 100 & 22.1 \\
\hline Carduelis spinus & 13.3 & 1.8 & 3.7 & 26.9 & 85 & 18.1 \\
\hline Carduelis cannabina & 21.0 & 1.4 & 13.9 & 30.3 & 89 & 19.2 \\
\hline Carduelis flavirostris & 0.7 & 0.5 & 0.0 & 6.5 & 40 & 9.7 \\
\hline Carduelis flammea & 0.9 & 0.3 & 0.0 & 2.7 & 64 & 12.6 \\
\hline Loxia curvirostra & 1.2 & 0.8 & 0.0 & 10.8 & 90 & 19.1 \\
\hline Pyrrhula pyrrhula & 30.4 & 3.4 & 16.7 & 54.4 & 95 & 21.0 \\
\hline Coccothraustres coccothraustes & 28.7 & 1.8 & 20.7 & 43.8 & 99 & 22.9 \\
\hline Calcarius lapponicus & 0.4 & 0.4 & 0.0 & 5.0 & 30 & 8.5 \\
\hline Plectrophenax nivalis & 0.7 & 0.3 & 0.0 & 2.9 & 57 & 13.5 \\
\hline Emberiza citrinella & 34.6 & 1.3 & 26.0 & 40.2 & 94 & 20.1 \\
\hline Emberiza cirlus & 0.5 & 0.3 & 0.0 & 2.3 & 44 & 8.0 \\
\hline Emberiza cia & 0.1 & 0.1 & 0.0 & 1.5 & 60 & 12.2 \\
\hline Emberiza schoeniclus & 19.4 & 2.0 & 11.8 & 32.4 & 74 & 17.2 \\
\hline Miliaria calandra & 4.6 & 0.8 & 1.1 & 12.1 & 88 & 20.2 \\
\hline
\end{tabular}

Supplement 3. Relative density (individual $/ \mathrm{km}^{2}$ ) in the main habitat types (mean, SE and number of points considered), habitat occupancy of the surveyed population in the main habitat types (\% of the estimated population in the given habitat compared to the entire population) and number of estimated individuals of the given species on the base of the relative density and area of habitat types in Hungary, using data collected between 1999-2012 following the MMM standard protocol in Hungary

Melléklet 3. Az MMM keretében 1999-2012 során megfigyelt fészkelő madárfajok relatív denzitása (egyed $/ \mathrm{km}^{2}$ ) a fő élőhely típusokban (urbán, mezőgazdasági, erdei, vizes) (átlag, átlag hibája (SE) , a megfigyelt pontok száma), élőhely használata (az adott élőhelyen megfigyelt állomány aránya (\%) a négy fó élőhelyen becsült állományhoz képest), a négy fő élőhelyen együttesen élő egyedek számának becslése a fő élőhelyeken becsült relatív denzitás és az adott élőhely magyarországi kiterjedése alapján 


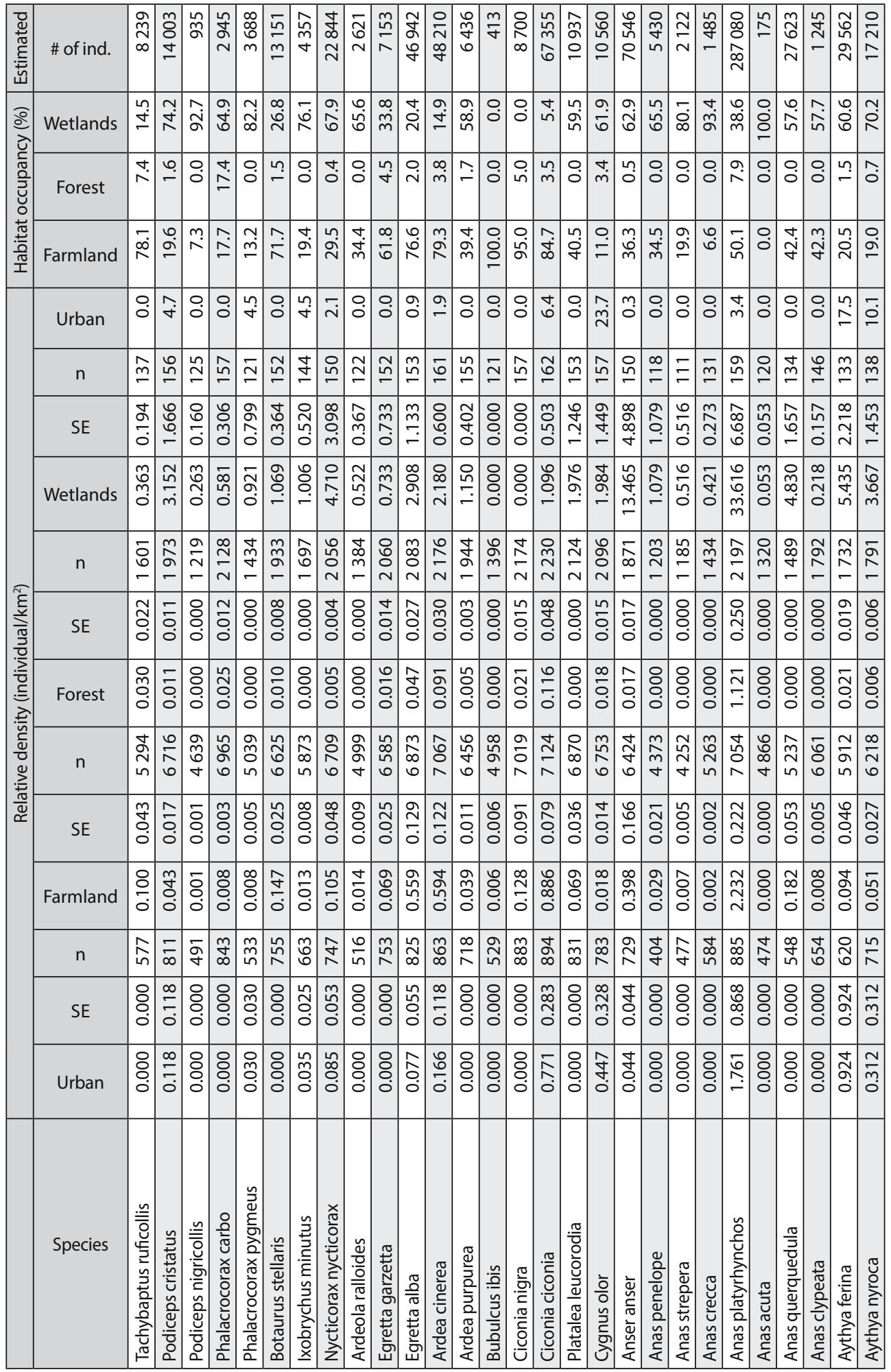




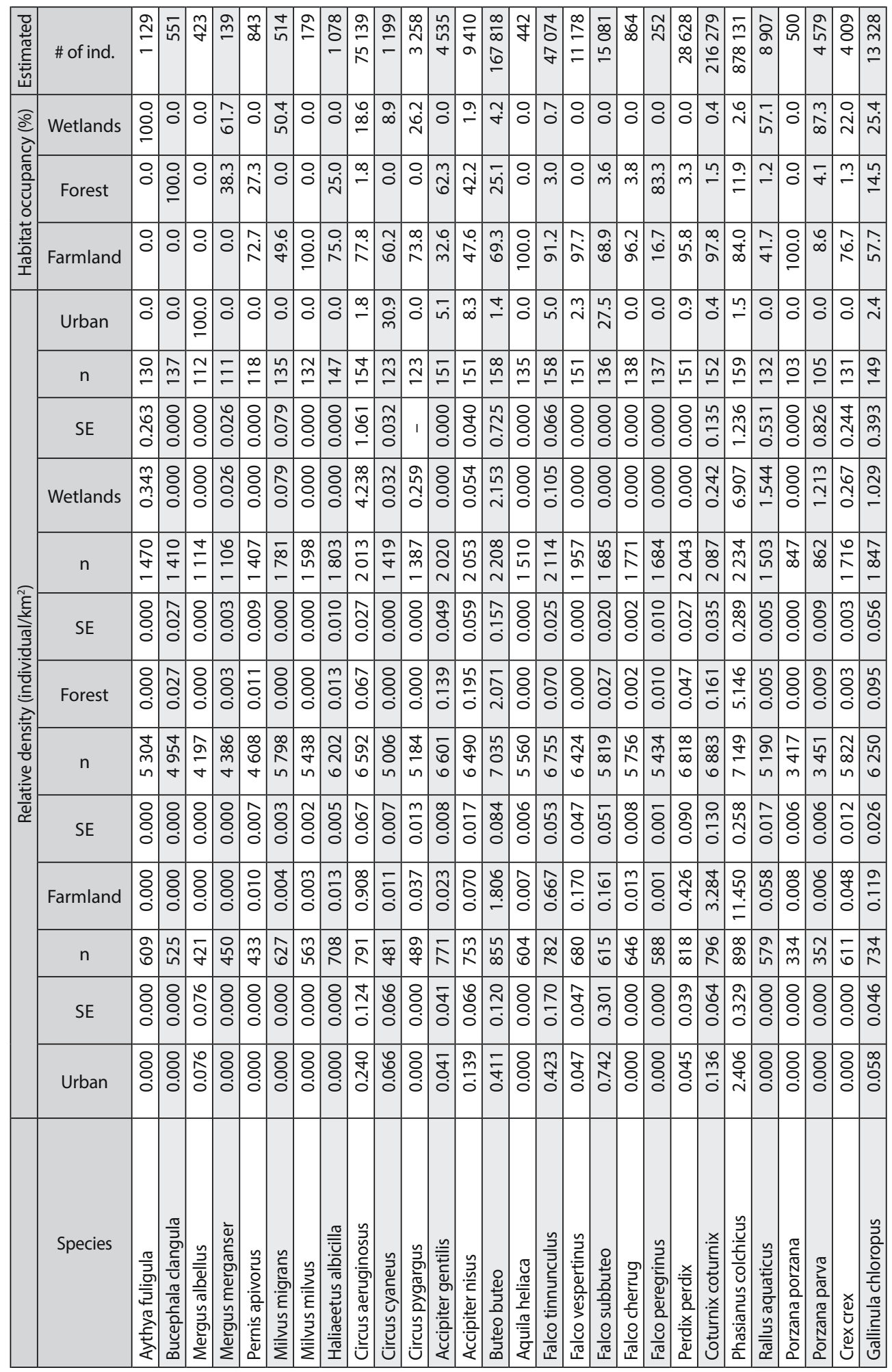




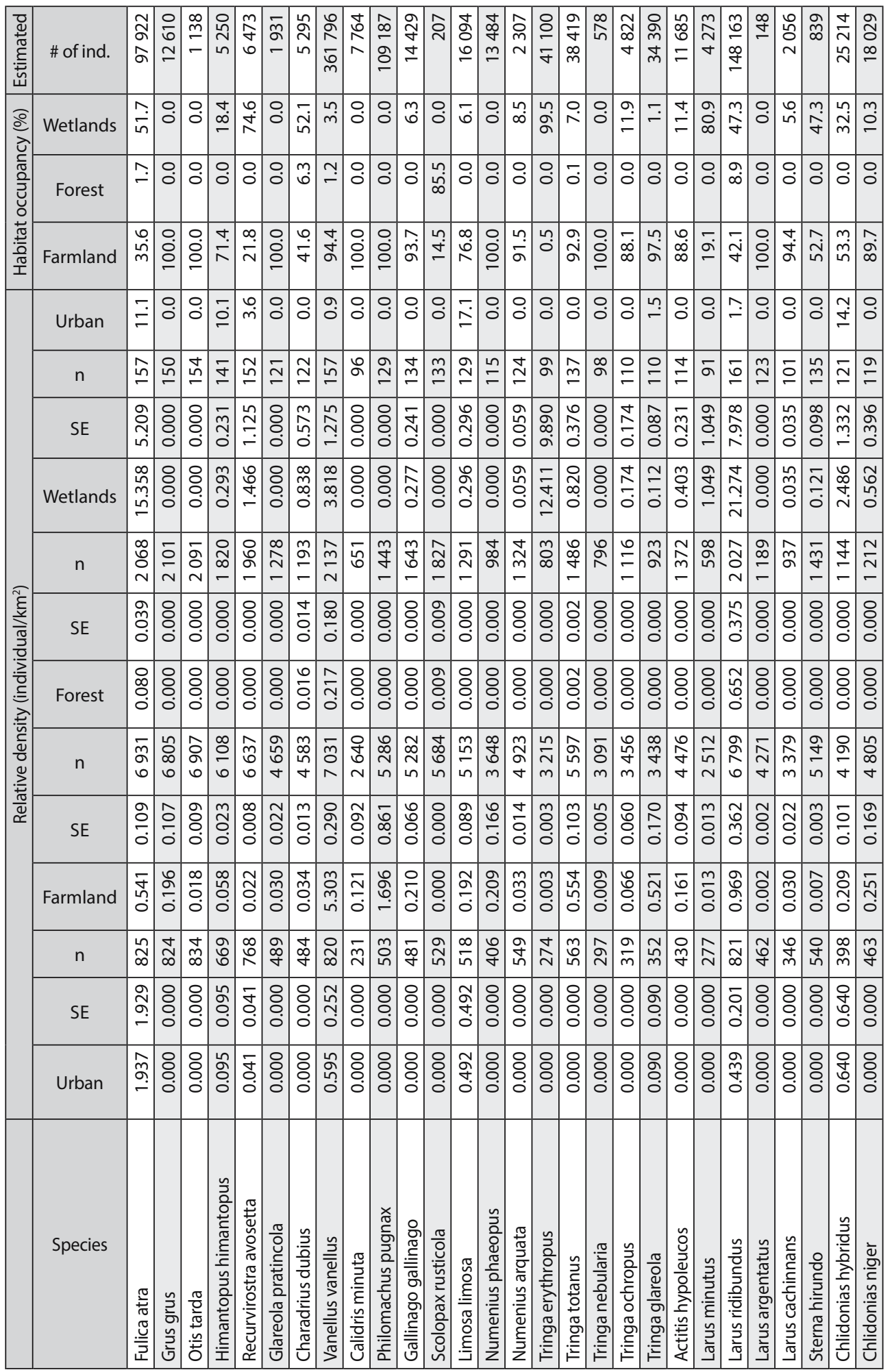




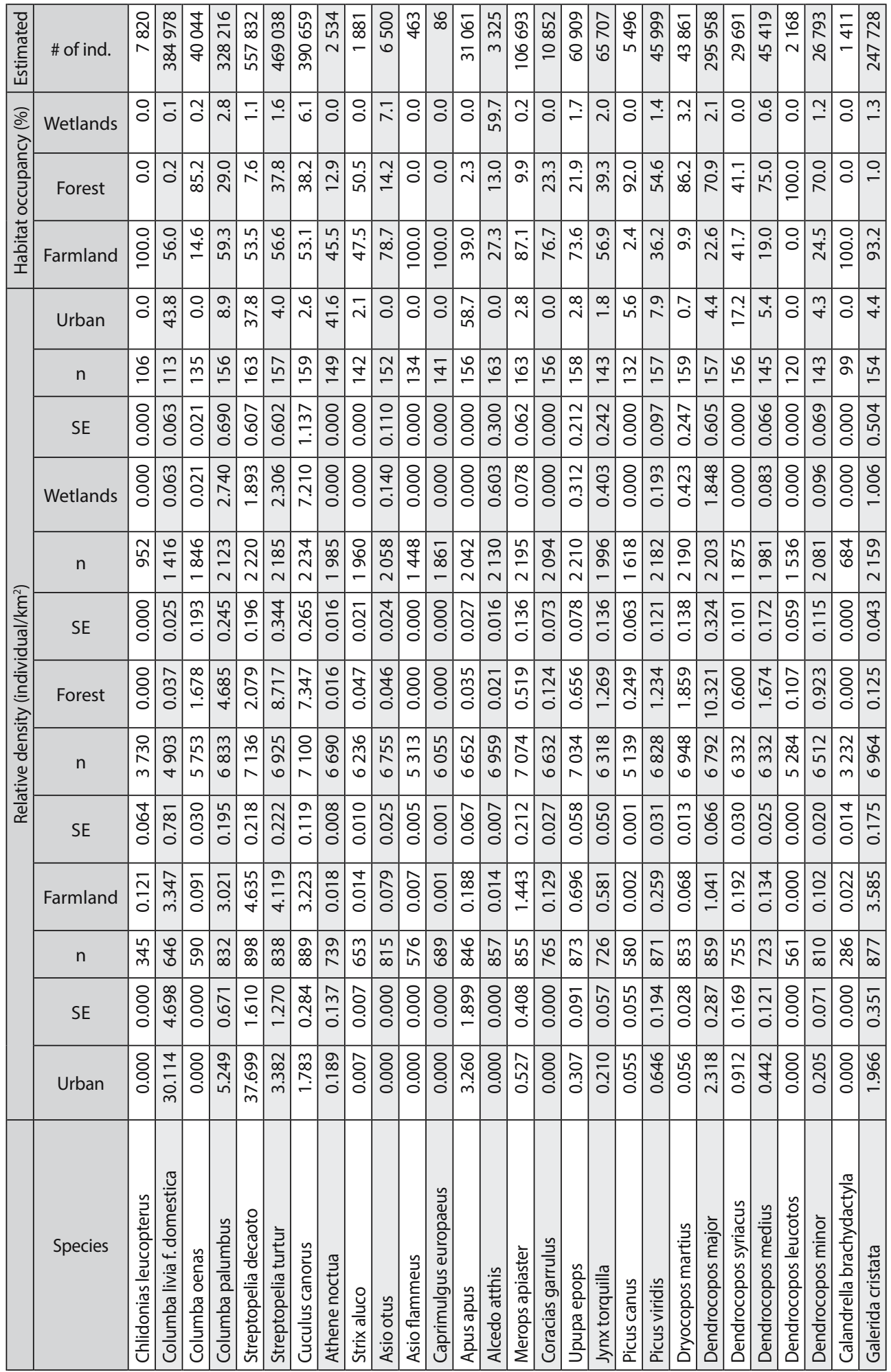




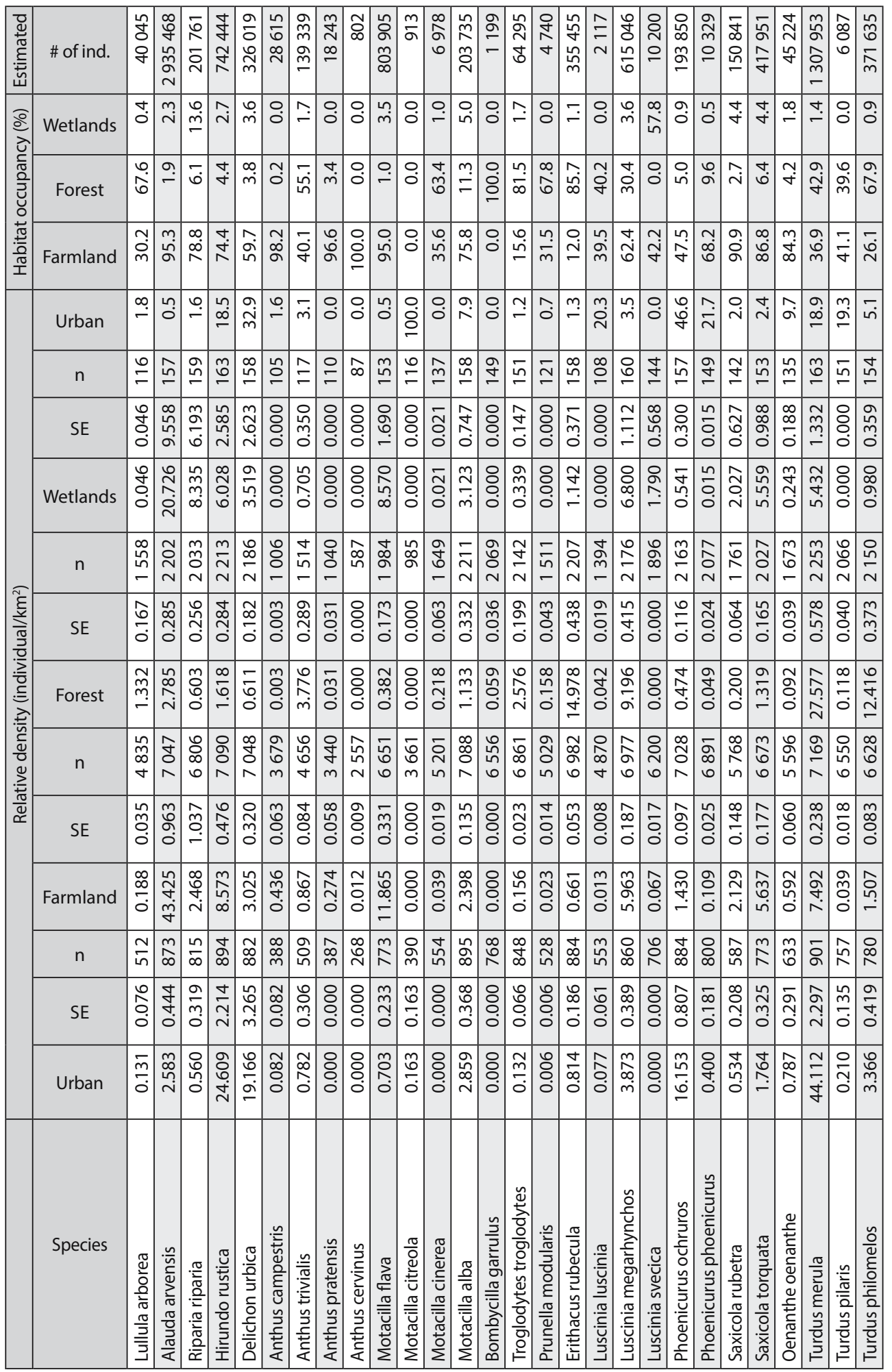




\begin{tabular}{|c|c|c|c|c|c|c|c|c|c|c|c|c|c|c|c|c|c|c|c|c|c|c|c|c|c|c|c|c|c|c|}
\hline 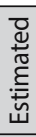 & \# of ind. & v. & \begin{tabular}{|l|} 
\\
0 \\
$m$ \\
-
\end{tabular} & \begin{tabular}{|l}
$\stackrel{P}{0}$ \\
$\infty$ \\
$\hat{m}$
\end{tabular} & $\begin{array}{l}a \\
\underset{m}{m} \\
\sim \\
\infty\end{array}$ & $\begin{array}{l}2 \\
2 \\
2 \\
2\end{array}$ & $\begin{array}{l}8 \\
0 \\
m\end{array}$ & \begin{tabular}{l}
8 \\
\hdashline \\
-
\end{tabular} & $\begin{array}{l}\text { Ln } \\
\text { مn } \\
\text { oे }\end{array}$ & 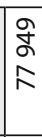 & 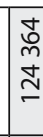 & 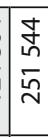 & 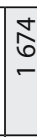 & $\underset{m}{m}$ & $\begin{array}{l}m \\
f \\
f \\
\stackrel{f}{f}\end{array}$ & 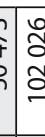 & & & & & & & & & $\approx$ & $\begin{array}{c}+ \\
m \\
0\end{array}$ & 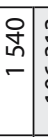 & & 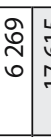 & 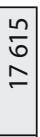 \\
\hline$\frac{0}{x}$ & Wetlands & O̊ & : & \begin{tabular}{|l|} 
\\
\end{tabular} & बे. & $\begin{array}{l}\infty \\
\dot{f} \\
\end{array}$ & $\begin{array}{l}\stackrel{\check{N}}{\nu} \\
\end{array}$ & $\because$ & 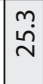 & ? & $\begin{array}{l}9 \\
\text { I }\end{array}$ & $\frac{\sigma}{N}$ & ○. & $\underset{n}{n}$ & $\stackrel{-}{-}$ & $\underbrace{m}_{m}$ & & $\dot{v}$ & ? & $?$ & '. & & L & & $0^{\circ}$ & $\stackrel{\dot{m}}{\dot{m}}$ & ○. & $\overline{0}$ & : & $\hat{\aleph}$ \\
\hline ఫ్ & Forest & 字 & \begin{tabular}{|c|} 
\\
\\
\end{tabular} & $\stackrel{\text { ? }}{=}$ & $\begin{array}{l}+ \\
\infty \\
m\end{array}$ & $\begin{array}{l}0 \\
\end{array}$ & $\stackrel{\circ}{\circ}$ & $\begin{array}{l}\hat{n} \\
\text { in }\end{array}$ & $\stackrel{9}{-}$ & f & i & in & ○. & $\mid$ & i̊ & $\begin{array}{l}\dot{v} \\
\dot{v}\end{array}$ & & 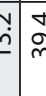 & 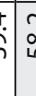 & $\begin{array}{l}y \\
\vdots \\
\vdots \\
n\end{array}$ & 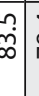 & م. & $\frac{m}{6}$ & ఫু & 离 & in & $\begin{array}{l}1 \\
\text { in }\end{array}$ & 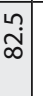 & $\begin{array}{l}\widehat{c} \\
\infty \\
i^{\prime}\end{array}$ & $\stackrel{\circ}{\circ}$ \\
\hline $\begin{array}{l}\frac{0}{\pi} \\
\frac{\pi}{1}\end{array}$ & Farmland & $\begin{array}{l} \\
\text { ì }\end{array}$ & $\begin{array}{l}\stackrel{9}{0} \\
0\end{array}$ & $\begin{array}{c}m \\
\substack{n \\
\infty}\end{array}$ & in & $\begin{array}{l}m \\
\dot{o} \\
\dot{o}\end{array}$ & ț & \begin{tabular}{l}
$m$ \\
\multirow{f}{*}{} \\
\end{tabular} & $\stackrel{m}{N}$ & $\stackrel{\substack{\infty \\
\infty}}{\stackrel{2}{n}}$ & $\infty$ & : & ㅇ. & o & $\stackrel{n}{N}$ & $=\frac{0}{0}$ & & 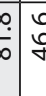 & & & $\underset{\forall}{*}$ & $\begin{array}{c}m \\
\infty \\
\infty\end{array}$ & : & on & 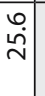 & $\begin{array}{l}0 \\
0 \\
m \\
m\end{array}$ & $\begin{array}{l}0 \\
\dot{m} \\
\dot{m}\end{array}$ & 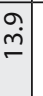 & $\begin{array}{l}0 \\
\dot{g} \\
\dot{q}\end{array}$ & $\begin{array}{l}\infty \\
\stackrel{\infty}{\sim} \\
\end{array}$ \\
\hline \multirow{13}{*}{ 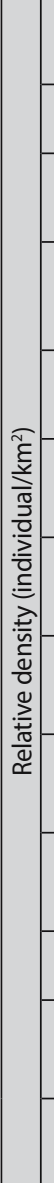 } & Urban & 0 & $\stackrel{n}{-}$ & $\stackrel{0}{-}$ & 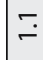 & ma & $\because$ & $\stackrel{\circ}{\circ}$ & L? & 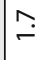 & O & $\stackrel{\leftrightarrow}{\sim}$ & ○. & 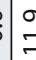 & $\stackrel{n}{?}$ & $=$ & 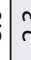 & $\stackrel{n}{i} \underset{z}{n}$ & 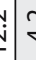 & $\begin{array}{l}\text { Yy } \\
\dot{\tau}\end{array}$ & $\stackrel{0}{\circ}$ & $\stackrel{-}{-}$ & $\therefore$ & $\stackrel{0}{\circ}$ & $\stackrel{\circ}{\circ}$ & $\stackrel{n}{\sim}$ & 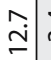 & $\stackrel{+}{\mathrm{m}}$ & $\hat{o}$ & ㅇ. \\
\hline & $\mathrm{n}$ & $\stackrel{ \pm}{\underset{I}{ \pm}}$ & $\stackrel{+}{m}$ & 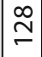 & $\stackrel{\infty}{m}$ & $\stackrel{\hat{m}}{\square}$ & $\stackrel{\sim}{\sim}$ & $\bar{ָ}$ & 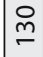 & $\stackrel{\circ}{m}$ & ริ & $\stackrel{g}{g}$ & $\hat{0}$ & $\underset{c}{\infty}$ & $\stackrel{m}{m}$ & $?$ & 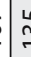 & $\hat{n} \tilde{n}$ & 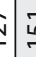 & $\bar{n}$ & 음 & $\stackrel{m}{ \pm}$ & $\underline{E}$ & 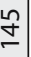 & 守 & 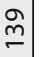 & $\stackrel{\infty}{\mp}$ & $\bar{\Phi}$ & $\stackrel{\stackrel{n}{m}}{\sim}$ & $\stackrel{\infty}{+}$ \\
\hline & SE & ○े & $\mid \begin{array}{l}8 \\
0 \\
0 \\
0\end{array}$ & $\frac{\sigma}{\sigma}$ & $\begin{array}{c}\stackrel{a}{r} \\
\hat{0}\end{array}$ & $\begin{array}{l}\bar{m} \\
\stackrel{n}{n}\end{array}$ & 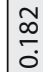 & 8 & 요 & $\begin{array}{l}0 \\
\text { on } \\
0\end{array}$ & $\underset{\sim}{\stackrel{J}{2}}$ & $\stackrel{\substack{m \\
m}}{\stackrel{m}{n}}$ & ষ & 悉 & $\frac{1}{5}$ & $=$ & & $\begin{array}{l}\overbrace{n}^{n} \\
\text { : }\end{array}$ & : & مَ & 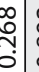 & $\begin{array}{l}\text { ָू } \\
\infty \\
0 \\
0\end{array}$ & ?ֶ. & $\begin{array}{l}8 \\
8 \\
0 \\
0\end{array}$ & $\begin{array}{l}8 \\
8 \\
0\end{array}$ & 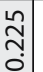 & \begin{tabular}{l}
8 \\
\hdashline \\
\end{tabular} & $\begin{array}{l}\bar{y} \\
\end{array}$ & \begin{tabular}{l} 
Q \\
\hdashline \\
\hdashline
\end{tabular} & 孚 \\
\hline & Wetlands & $\begin{array}{l}8 \\
0 \\
0\end{array}$ & \begin{tabular}{|l|} 
\\
\\
0 \\
\end{tabular} & $\begin{array}{l}\tilde{\infty} \\
\infty \\
0\end{array}$ & $\stackrel{\text { ్ }}{\text { N }}$ & $\begin{array}{l}\tilde{v} \\
\underline{m}\end{array}$ & $\begin{array}{l}\text { ஸे } \\
\text { ஸे } \\
0\end{array}$ & 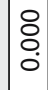 & $\begin{array}{l}\stackrel{\sim}{N} \\
\text { N} \\
\text { N }\end{array}$ & $\begin{array}{l}\stackrel{0}{n} \\
6 \\
m\end{array}$ & $\begin{array}{l}\frac{0}{m} \\
n \\
z\end{array}$ & 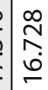 & \& & $\mid \begin{array}{l}\not \\
\infty \\
\infty \\
c\end{array}$ & 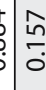 & 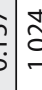 & 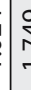 & $\underset{+}{+}$ & & & çm & $\stackrel{\substack{n \\
\sim}}{\sim}$ & 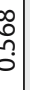 & \begin{tabular}{l}
8 \\
\hdashline \\
\hdashline \\
\hdashline
\end{tabular} & $\begin{array}{l} \\
\\
\\
\end{array}$ & $\begin{array}{l}\bar{\sigma} \\
\bar{\sigma} \\
0\end{array}$ & \begin{tabular}{l} 
\\
$\vdots$ \\
\hdashline
\end{tabular} & $\begin{array}{l}\bar{\delta} \\
\text { ¿ }\end{array}$ & \begin{tabular}{l} 
\\
\hdashline \\
\hdashline \\
0
\end{tabular} & 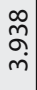 \\
\hline & $n$ & $\begin{array}{l}\overline{2} \\
-\end{array}$ & 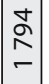 & 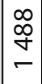 & $\begin{array}{l}\bar{N} \\
-\end{array}$ & $\begin{array}{l}\tilde{n} \\
\\
-\end{array}$ & $\stackrel{\text { Iิ }}{=}$ & $\begin{array}{l}\mathbb{O} \\
-\end{array}$ & 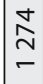 & $\begin{array}{l}\tilde{T} \\
m \\
-\end{array}$ & $\stackrel{\circ}{7}$ & $=\frac{l}{4}$ & 응 & $\stackrel{2}{\beth}$ & $\widehat{v}$ & $\begin{array}{l}c \\
\\
\end{array}$ & 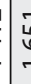 & $\begin{array}{c}\hat{0} \\
- \\
\end{array}$ & & 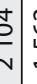 & 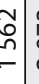 & $\begin{array}{l}\text { ñ } \\
\text { in }\end{array}$ & 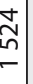 & $\begin{array}{l}0 \\
\tilde{n} \\
\swarrow \\
-\end{array}$ & $\begin{array}{c}\hat{\infty} \\
-\end{array}$ & $\begin{array}{c}\stackrel{+}{\infty} \\
\infty \\
-\end{array}$ & $\begin{array}{l}0 \\
0 \\
\sim \\
-\end{array}$ & & & $\begin{array}{l}\tilde{n} \\
\tilde{\sigma} \\
-\end{array}$ \\
\hline & SE & $\begin{array}{l}0 \\
0 \\
0\end{array}$ & \begin{tabular}{|l|}
0 \\
0 \\
0 \\
0 \\
0
\end{tabular} & $\mid \begin{array}{l}\tilde{N} \\
0 \\
0 \\
0\end{array}$ & 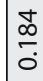 & \begin{tabular}{|l}
0 \\
0 \\
0 \\
0
\end{tabular} & 웅 & $\begin{array}{l}1 \\
0 \\
0 \\
0\end{array}$ & $\begin{array}{l}\hat{\alpha} \\
\text { o. } \\
\end{array}$ & ò & 点 & 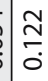 & ঃ & 约 & 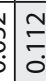 & $=$ & & $\frac{n}{j}$ & & గ్రి & $\begin{array}{c}\infty \\
m \\
m \\
0 \\
\vdots\end{array}$ & 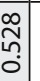 & 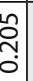 & $\begin{array}{l}\tilde{0} \\
\vdots \\
0\end{array}$ & $\begin{array}{l}\hat{\tilde{m}} \\
0 \\
\dot{0}\end{array}$ & \begin{tabular}{c}
$\widetilde{0}$ \\
\hdashline \\
0
\end{tabular} & $\begin{array}{l}m \\
\vdots \\
\vdots \\
0\end{array}$ & $\overline{\bar{m}}$ & $\begin{array}{l}\tilde{n}^{2} \\
0 \\
0\end{array}$ & $\mid \begin{array}{l}1 \\
\vdots \\
0 \\
0\end{array}$ \\
\hline & Forest & $\begin{array}{l}0 \\
\vdots \\
0 \\
\end{array}$ & 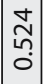 & $\begin{array}{l}\tilde{T} \\
\tilde{\sigma} \\
\end{array}$ & 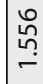 & 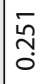 & 웅 & $\begin{array}{l}\hat{0} \\
0 \\
0\end{array}$ & $\begin{array}{l}\text { กิ } \\
\text { స్ }\end{array}$ & $\stackrel{\bar{\infty}}{\stackrel{\infty}{\circ}}$ & $\underset{\sim}{\stackrel{\Xi}{\circ}}$ & $\begin{array}{l}\infty \\
0 \\
0\end{array}$ & ঃి & 党 & $\begin{array}{l}n \\
\vdots \\
\vdots \\
0\end{array}$ & 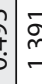 & & 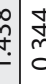 & 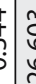 & 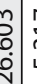 & s. & 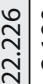 & $\begin{array}{l}\frac{a}{2} \\
\stackrel{i}{v}\end{array}$ & 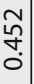 & $\begin{array}{l}0 \\
\vdots \\
0 \\
0\end{array}$ & $\stackrel{\substack{n\\
}}{\square}$ & $\begin{array}{l}\infty \\
\tilde{o} \\
0 \\
0\end{array}$ & 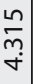 & \begin{tabular}{c}
$\bar{\infty}$ \\
\hdashline \\
\end{tabular} & 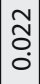 \\
\hline & n & $\begin{array}{l}n \\
0 \\
m \\
n \\
n\end{array}$ & $\mid \begin{array}{l}0 \\
m \\
i n \\
\text { in }\end{array}$ & $\mid \begin{array}{l}\tilde{N} \\
\sigma \\
\gamma \\
\end{array}$ & $\underset{\text { in }}{\stackrel{2}{\sim}}$ & $\begin{array}{l}m \\
\text { O⿱⿴囗十丌 } \\
\text { in }\end{array}$ & $\begin{array}{l}\text { ¿ } \\
\text { m }\end{array}$ & $\begin{array}{c}\infty \\
m \\
m \\
\sigma\end{array}$ & $\begin{array}{l}\bar{f} \\
\sigma\end{array}$ & 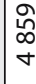 & 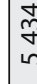 & $\begin{array}{l}n \\
\hat{b} \\
0\end{array}$ & $\underset{f}{q}$ & {$\left[\begin{array}{l}\infty \\
m \\
0 \\
\sigma\end{array}\right.$} & 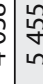 & 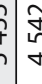 & & 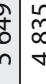 & & $\begin{array}{l}\hat{y} \\
0 \\
0 \\
0\end{array}$ & 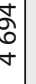 & $\begin{array}{c}\hat{\imath} \\
\hat{m} \\
0\end{array}$ & 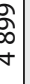 & $\begin{array}{l}\hat{N} \\
\text { O }\end{array}$ & $\frac{9}{\frac{g}{6}}$ & $\begin{array}{l}m \\
0 \\
\text { in }\end{array}$ & 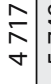 & $\begin{array}{l}\stackrel{a}{+} \\
\text { in }\end{array}$ & 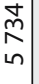 & $\mid \begin{array}{c}\bar{N} \\
0\end{array}$ \\
\hline & SE & $\begin{array}{l}m \\
0 \\
0\end{array}$ & $\bar{\sigma}$ & 茖 & $\hat{\theta}$ & ठ্ & $\tilde{\sigma}_{0}$ & $\begin{array}{l}0 \\
0 \\
0 \\
0\end{array}$ & 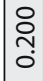 & ठू & o & 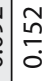 & $\begin{array}{l}0 \\
\stackrel{2}{0} \\
0\end{array}$ & a & $\overline{8}$ & 羡 & & 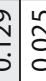 & 3 & $\frac{6}{0}$ & o & $\begin{array}{l}\text { mo } \\
\text { o. }\end{array}$ & $\begin{array}{l}n \\
0 \\
0 \\
0\end{array}$ & $\begin{array}{l}8 \\
\vdots \\
0 \\
0\end{array}$ & $\begin{array}{l}0 \\
\vdots \\
0\end{array}$ & $\begin{array}{l}0 \\
0 \\
0 \\
0\end{array}$ & $\begin{array}{l}\dot{0} \\
\dot{0}\end{array}$ & $\begin{array}{l}0 \\
\vdots \\
0 \\
0\end{array}$ & $\begin{array}{l}\tilde{N} \\
0 \\
0 \\
0\end{array}$ & 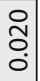 \\
\hline & Farmland & $\begin{array}{l}m \\
0 \\
0\end{array}$ & 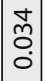 & $\begin{array}{l}\bar{\delta} \\
0 \\
0 \\
0\end{array}$ & $\begin{array}{l}\text { t్ర } \\
0 \\
0\end{array}$ & $\begin{array}{l}n \\
\hat{n} \\
0 \\
0\end{array}$ & 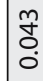 & $\frac{0}{0}$ & \begin{tabular}{|l}
$\stackrel{n}{f}$ \\
$\stackrel{r}{m}$
\end{tabular} & 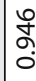 & ¿ & $\stackrel{\substack{\stackrel{\infty}{\sim} \\
\sim}}{\sim}$ & 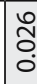 & 5 & 过 & 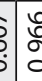 & & 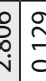 & 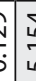 & $\frac{n}{n}$ & 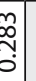 & $\begin{array}{l}\text { ơ } \\
0 \\
\end{array}$ & 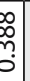 & $\begin{array}{l}0 \\
8 \\
0 \\
0\end{array}$ & $\begin{array}{l}0 \\
0 \\
0\end{array}$ & $\begin{array}{c}n \\
\hat{n} \\
m \\
0\end{array}$ & $\begin{array}{l}0 \\
\dot{0} \\
\dot{0}\end{array}$ & 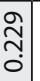 & $\begin{array}{l}0 \\
\stackrel{9}{0} \\
0\end{array}$ & $\begin{array}{l}0 \\
0 \\
0\end{array}$ \\
\hline & $\mathrm{n}$ & in & $\bar{\delta}$ & 足 & 고 & $\frac{\infty}{\text { in }}$ & $\stackrel{\infty}{\frac{\infty}{m}}$ & 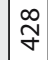 & $\begin{array}{l}\circ \\
\stackrel{\infty}{+}\end{array}$ & ষ্ণ & $\stackrel{\infty}{\mathfrak{u}^{\prime}}$ & $\frac{8}{N}$ & $\bar{\sim}$ & $\stackrel{n}{\partial}$ & $\begin{array}{l}0 \\
f\end{array}$ & $\hat{h}$ & & $\begin{array}{l}f \\
\end{array}$ & 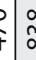 & $\begin{array}{l}\infty \\
n \\
\infty\end{array}$ & $\mathbb{N}$ & $\frac{m}{\infty}$ & Љ) & $\bar{m}$ & $\frac{0}{1}$ & 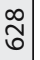 & ถิ & ᄋ్̣ & $\stackrel{t}{\stackrel{t}{n}}$ & 잇 \\
\hline & SE & $\begin{array}{l}0 \\
\vdots \\
0\end{array}$ & \begin{tabular}{|l}
$\overline{0}$ \\
0 \\
0
\end{tabular} & $\begin{array}{l}\bar{T} \\
0 \\
0\end{array}$ & 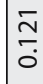 & 角. & O্ & $\begin{array}{l}8 \\
0 \\
0\end{array}$ & స̃ & $\stackrel{m}{\sigma}$ & $\bar{\Xi}$ & 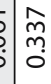 & ¿ & $\frac{9}{a}$ & $\frac{0}{0}$ & 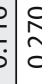 & $?$ & $\frac{\pi}{5}$ & 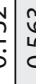 & 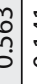 & $\frac{\sigma}{0}$ & 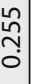 & . & \begin{tabular}{l}
8 \\
\hdashline \\
0 \\
0
\end{tabular} & $\begin{array}{l}0 \\
0 \\
0 \\
0\end{array}$ & $\begin{array}{c}\stackrel{5}{\Delta} \\
\vdots \\
0\end{array}$ & $\begin{array}{l}n \\
\tilde{n} \\
0 \\
0\end{array}$ & $\begin{array}{l}\text { ڤ్ } \\
\stackrel{2}{0}\end{array}$ & $\begin{array}{l}\infty \\
\stackrel{0}{0} \\
\vdots \\
0\end{array}$ & $\begin{array}{l}\stackrel{0}{0} \\
\vdots \\
\end{array}$ \\
\hline & Urban & 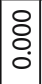 & \begin{tabular}{|c|} 
\\
0 \\
0 \\
0
\end{tabular} & $\frac{\Xi}{\sigma}$ & 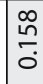 & ז̊. & o & 8 & స్ & 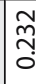 & o & 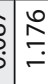 & ষ্ণ & & 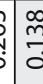 & $\begin{array}{l}\vdots \\
\vdots \\
\vdots\end{array}$ & & 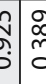 & & f. & $\begin{array}{l}\infty \\
0 \\
\\
0\end{array}$ & $\stackrel{\overbrace{}}{\stackrel{\imath}{*}}$ & . & 0 & ৪্. & $\begin{array}{l}0 \\
0 \\
0 \\
0 \\
0\end{array}$ & $\begin{array}{l}n \\
\tilde{o} \\
0 \\
0\end{array}$ & $\begin{array}{l}n \\
\hat{0} \\
0 \\
0\end{array}$ & \begin{tabular}{l}
$\infty$ \\
\hdashline \\
\hdashline \\
\hdashline
\end{tabular} & $\begin{array}{l}8 \\
\vdots \\
\circ\end{array}$ \\
\hline & Species & 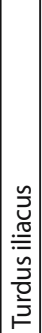 & 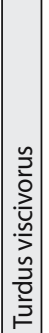 & 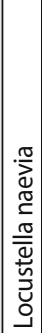 & 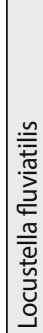 & 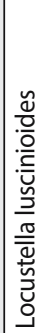 & 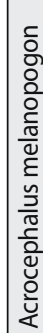 & 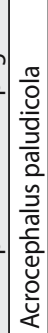 & 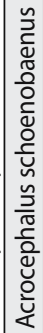 & 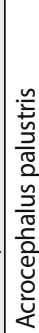 & 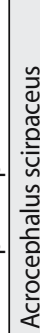 & 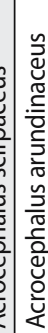 & 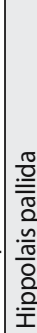 & 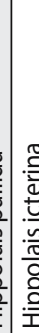 & 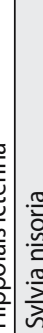 & 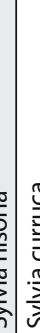 & & 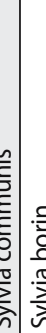 & 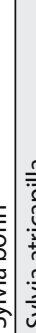 & 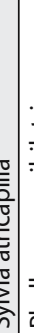 & 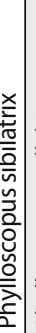 & 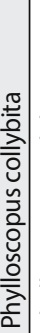 & & & 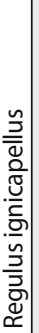 & 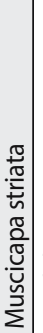 & $\begin{array}{l}\frac{\pi}{2} \\
\frac{2}{\pi} \\
\frac{0}{0} \\
\frac{\pi}{5} \\
\frac{0}{0} \\
\frac{0}{4}\end{array}$ & 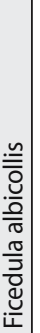 & 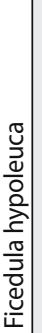 & 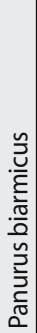 \\
\hline
\end{tabular}




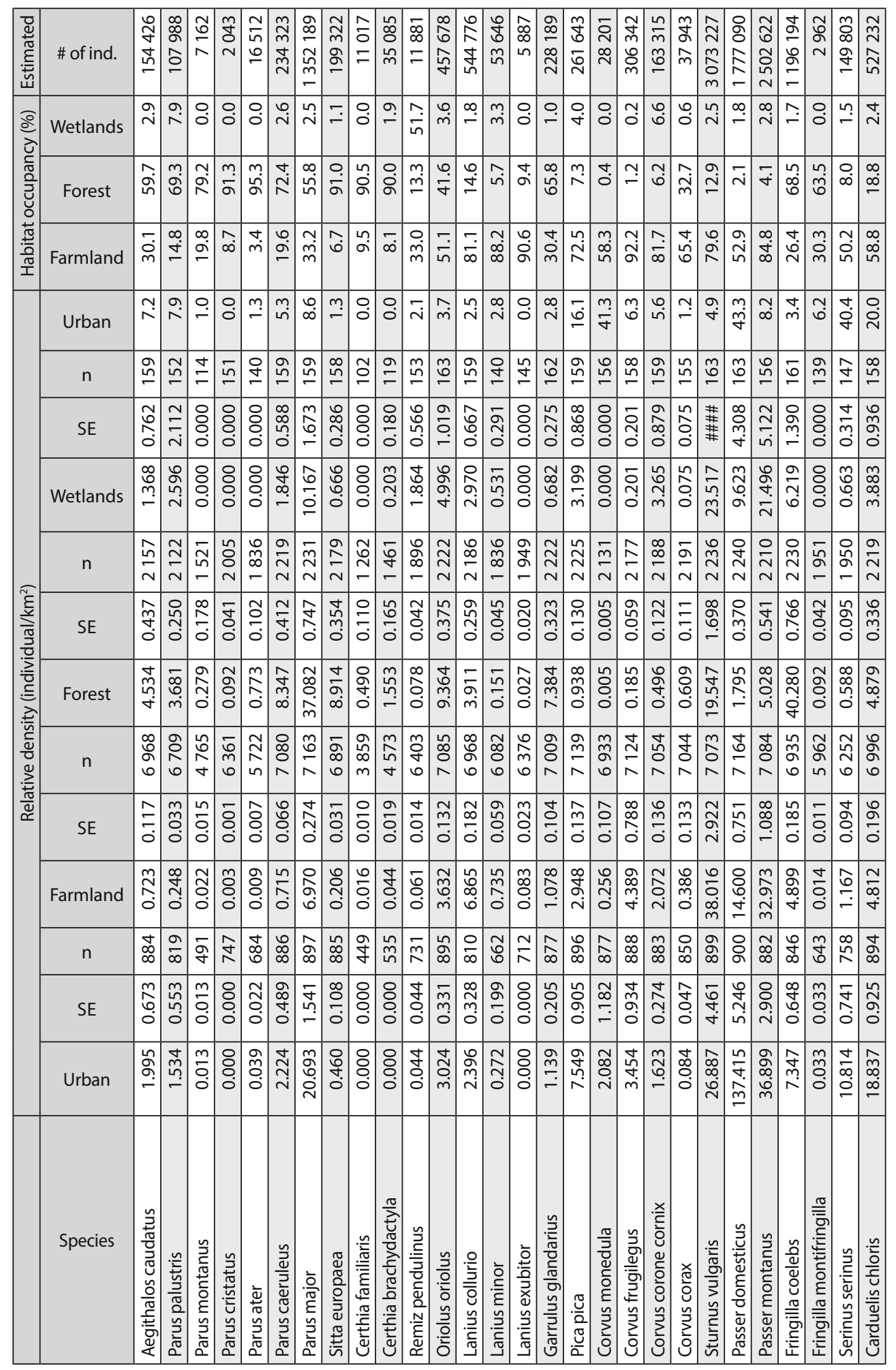




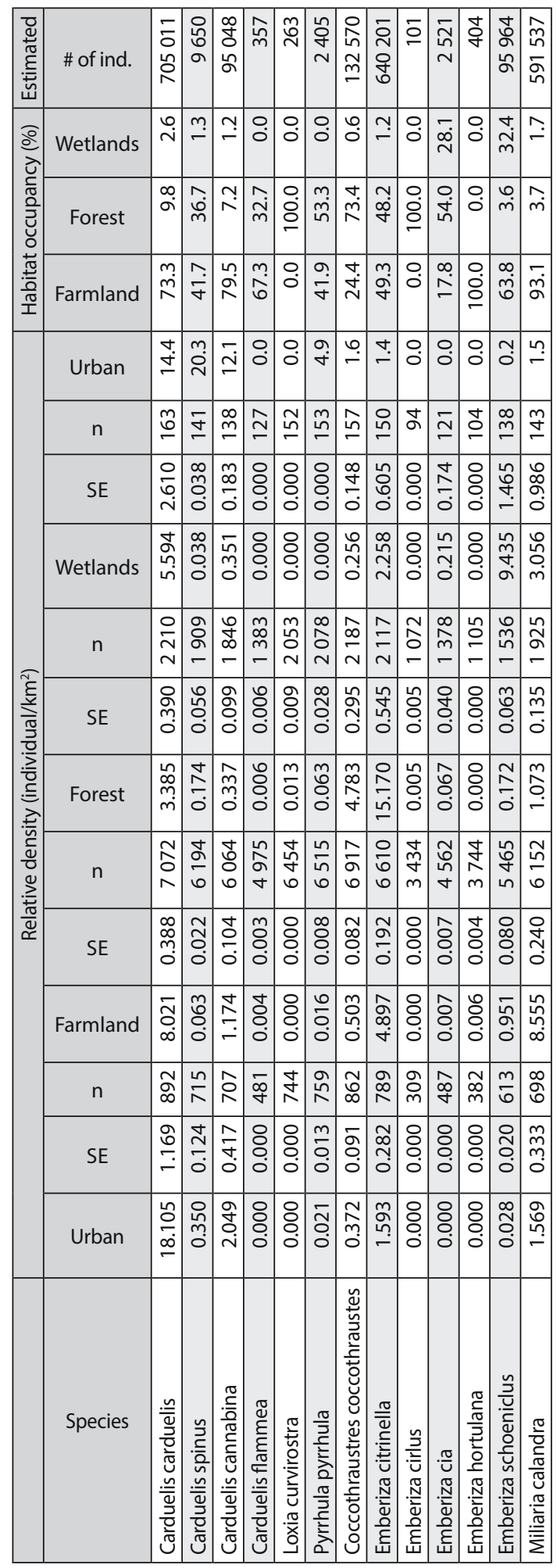

